\title{
PENERAPAN GMP DAN PERENCANAAN PELAKSANAAN \\ HACCP (Hazard Analysis Critical Control Point) PRODUK OLAHAN PANGAN TRADISIONAL (Mochi)
}

\author{
Oleh : \\ Wildan Wibawa Perdana, ST., MT. \\ Teknologi Pangan Universitas Al-Ghifari Bandung. \\ wildan.w.perdana@gmail.com / wildan.w.perdana@unfari.ac.id
}

\begin{abstract}
HACCP(Hazard AnalyticalCritical ControlPoint/Hazard analysis and critical control points) is a system thatcontrolfood safetystarting fromthe farmtoeatable food.This system emphasizesthe importance of selectingthe right technology andhowto validatethetechnology. The implementation of GMP isfollowedin the form ofSSOP which areadded value forfoodcompaniesto be ablepenetrate the export market, in accordance with trade firms of target country.

This study aimed toevaluate the condition ofthe basicfeasibility requirementsin line with the requirementsof GMPandHACCP, analyzing the Implementation ofSOPbased onthe critical pointsas aguidance of theimprovement of production processes, Arrangingthe HACCP plandocument $(\mathrm{H} A C C P$ plan)forproductionas a guidein the implementation ofthe HACCP system, Recommendthe HACCP planfor the development ofHACCP system, andredesignthe layout ofthe facilityafterseeingaspects ofdeviations thatoccur inthe production process.

The evaluation results towardsthe basicfeasibility requirements condition orgoodmanufacturingpractice(GMP) inCV. Ruyaprima Utama had been found 9 deviations in the field; 6 of themare categorizedasmajordeviationsand3minordeviationswbich were divided intoseven sections: Building aspects with 2 minor deviations, sanitation facility aspects with 1 minor deviation, employee hygiene aspects (employee bealth, bygiene and habits) with 2 major deviations, storage aspects with 1 major deviations, processing facilities maintanance and sanitation along with pest controlling aspects 1 major deviations and management and training aspects with 1 major deviations. Sanitation Standard Operating Procedures (SSOP) is a standard procedure that can cover the entire area in producing a food product started from the company's policy, the stages of sanitation activities, the officer responsible for sanitation, how to monitor, and documentation through evaluation of GMP. The nine deviations in the company must be repaired before applying the HACCP system.

The results of hazard analysis for mochi's production of CV Ruyaprima Utama showed a negative pathogen bacteria content (Salmonella, E. Coli, Stapbylococcus and fungi). Total Plate Count analysis showed $<100$ colonies per gram, this result was still below the required maximum limit of 106 colonies I gram. Based on Identification of CCPs have been conducted, it was found that the two processes have a CCP. First, the sugar heating process in the way it cooked until melted. Second, manually printing process where directly has a contact with employees.
\end{abstract}

Keyword : HACCP, GMP, SSOP

PENERAPAN GMP DAN
PERENCANAAN PELAKSANAAN
HACCP (Hazard Analysis Critical Control
Point) PRODUK OLAHAN PANGAN
TRADISIONAL (Mochi)

PENERAPAN

HACCP (Hazard Analysis Critical Control TRADISIONAL (Mochi)
WILDAN WIBAWA PERDANA 


\section{PENDAHULUAN}

Industri kecil dan menengah (IKM) di Indonesia merupakan salah satu pendorong terdepan dalam pembangunan ekonomi. IKM dapat menciptakan lapangan pekerjaan lebih cepat dibandingkan sektor usaha lainnya, keberadaannya juga cukup memberikan kontribusi penting dalam ekspor dan perdagangan. Keterlibatan masyarakat luas dalam usaha industri pangan lokal saat ini sudah terjadi di berbagai daerah, khususnya melalui tumbuhnya industri kecil dan rumah tangga bidang pengolahan pangan (Hariyadi, 2010).

Data BPS juga menunjukkan bahwa sekitar 53,57\% dari semua usaha atau industri kecil dan menengah (IKM) ini bergerak pada bidang pangan dan pertanian. Karena itu, industri aneka pangan lokal perlu diarahkan pada pengembangan dan pemberdayaan IKM di bidang pangan dan pengolahan hasil pertanian, sehingga mampu menyediakan pangan yang aman, bermutu, dan bergizi bagi masyarakatnya.

Dalam rangka memasuki era globalisasi yang berdampak terhadap sistem perdagangan international yang bebas dan lebih terbuka. Perdagangan global juga memberikan dampak terhadap industri makanan minuman dengan munculnya isu keamanan pangan. Menurut Peraturan Pemerintah Nomor 28 tahun 2004 tentang Keamanan, Mutu dan Gizi Pangan, keamanan pangan adalah kondisi dan upaya yang diperlukan untuk mencegah pangan dari kemungkinan cemaran biologis, kimia dan benda lain yang mengganggu, merugikan dan membahayakan kesehatan manusia.

Keamanan pangan, masalah dan dampak penyimpangan mutu, serta kekuatan, kelemahan, peluang dan ancaman dalam pengembangan sistem mutu industri pangan merupakan tanggung jawab bersama antara pemerintah, industri dan konsumen.Keamanan pangan menangani keberadaan unsur bahaya yang terkandung dalam bahan pangan.
Menurut Muhandri dan Kadarisman (2006) karakteristik yang harus dipertimbangkan untuk produk olahan pangan yang aman antara lain: mutu bahan baku, metoda proses, kontaminasi pasca proses dan penentuan titik kendali kritis. Unsur-unsur bahaya ini mencakup racun biologis, hasil reaksi kimia serta kontaminasi terhadap fisik pangan, dan dapat diidentifikasi melalui komponen analisis bahaya dari HACCP. HACCP (Analisis Bahaya dan Pengendalian Titik Kritis) adalah sistem yang mengendalikan keamanan pangan mulai dari pertanian sampai menjadi bahan siap santap. Sistem ini menekankan pentingnya pemilihan teknologi yang tepat dan bagaimana cara melakukan validasi terhadap teknologi tersebut.

Penerapan GMP, diikuti dengan dokumentasi dalam bentuk SSOP, merupakan nilai tambah bagi perusahaan pangan untuk dapat menembus pasar ekspor, sesuai dengan peraturan perdagangan negara tujuan. Selain itu GMP yang sudah diterapkan dan disusun secara sistematis dalam bentuk SSOP, merupakan sebuah langkah maju untuk menuju pemenuhan persyaratan keamanan pangan karena GMP merupakan pra-syarat dalam pengaplikasian HACCP.

Penerapan program persyaratan dasar ini harus didokumentasikan dalam Sanitation Standard Operating Procedure (SSOP). Sedangkan dalam rangka monitoring dilakukan khusus audit terhadap persyaratan dasar ini baik internal maupun eksternal (Winarno dan Surono 2002).

Standard Sanitation Operating Procedures (SSOP) merupakan suatu prosedur standar yang dapat mencakup seluruh area dalam memproduksi suatu produk pangan mulai dari kebijakan perusahaan, tahapan kegiatan sanitasi, petugas yang bertanggung jawab melakukan sanitasi, cara pemantauan, hingga pendokumentasiannya (Thaheer, 2005).

Berbagai permasalahan tentang keamanan produk IKM pangan masih sangat

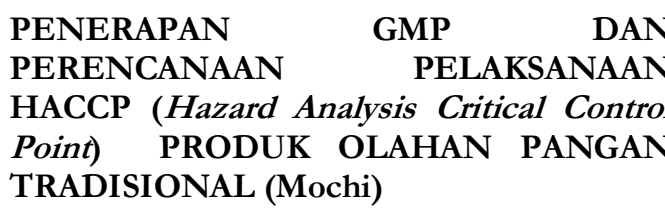

\section{WILDAN WIBAWA PERDANA}


memprihatinkan.Jika kondisi ini tidak ditangani serius, tidak mustahil justru akan menjadi beban kesehatan bagi bangsa (Hariyadi, 2010).

IKM mochi "Momi" merupakan perusahaan industri kecil dan menengah di Kabupaten Cianjur dengan produk mochi. Berdasarkan survei awal, IKM mochi "Momi" memiliki masalah yang berkaitan dengan sistem proses produksi, seperti halnya bangunan, tata letak produksi, karyawan dan berbagai faktor lainnya. Saat ini IKM mochi "Momi" masih belum menerapkan sistem HazardAnalysis Critical Control Point (HACCP) dan Standard Sanitation Operational Procedure(SSOP).

Menyadari pentingnya jaminan penerapan sistem manajemen mutu dan keamanan pangan di perusahaan serta menanggapi maraknya isu penggunaan bahan tambahan berbahaya dalam industri makanan dan adanya permintaan jaminan keamanan pangan dari pelanggan berdasarkan sistem HACCP, maka pihak manajemen IKM berkeinginan untuk menerapkan sistem HACCP (Hazard Analysis Critical Control Point).

\section{Identifikasi Masalah}

Permasalah yang dapat diidentifikasi berdasarkan latar belakang diatas adalah Bagaimana penerapan HACCP, SSOP, dan GMP dapat berperan penting dalam kontrol produksi dan dapat mengurangi bahaya yang mungkin terjadi pada produk serta dapat meningkatkan kualitas dari IKM.

\section{Maksud dan Tujuan}

Maksud dari penelitian ini adalah untuk Mengevaluasi kondisi persyaratan kelayakan dasar sesuai persyaratan GMP untuk selanjutnya dilakukan perancangan penerapan sistem HACCP atau HACCP plan.

Secara rinci penelitian ini bertujuan:

1. Mengevaluasi kondisi persyaratan kelayakan dasar sesuai persyaratan GMP dan HACCP.

2. Menganalisis atau Implementasi SOP berdasarkan titik-titik kritis yang

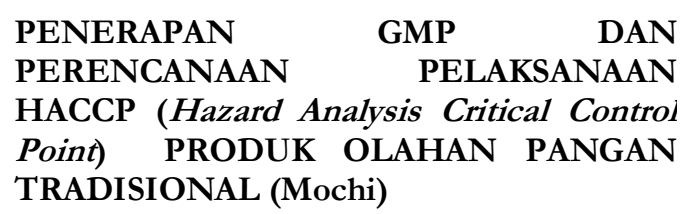

terdapat pada CV. Ruyaprima Utama sebagai panduan perbaikan proses produksi.

3. Menyusun dokumen rencana HACCP (HACCP Plan) untuk produksi di CV. Ruyaprima Utama yang akan digunakan perusahaan sebagai panduan dalam penerapan sistem HACCP.

4. Merekomendasikan rencana HACCP tersebut untuk pengembangan sistem HACCP CV. Ruyaprima Utama.

5. Perancangan ulang tata letak fasilitas dengan melihat aspek-aspek penyimpangan-penyimpangan yang terjadi pada proses pembuatan mochi.

Manfaat Penelitian penelitian ini diharapkan dapat dimanfaatkan untuk pribadi, program studi dan institusi, steak holder dan pemerintah sebagai :

1. Untuk memperkaya ilmu pengetahuan tentang teknologi pangan.

2. Referensi dan bahan acuan dalam upaya meningkatkan kualitas produk olahan terutama CV. Ruyaprima Utama.

3. Sumber kajian untuk pendampingan IKM.

4. Sebagai informasi penting yang mengungkap salah satu masalah mutu produk sehingga dapat dijadikan sebagai bahan pertimbangan bagi orang yang membutuhkan termasuk stakeholder dan pemerintah.

\section{Kerangka Penelitian}

Pemerintah Indonesia sebagai fasilitator dan regulator di bidang pangan telah mengeluarkan berbagai macam aturan agar setiap industri pangan mampu dan sanggup menghasilkan pangan yang memenuhi persyaratan keamanan, mutu dan gizi pangan bagi kepentingan kesehatan manusia serta tercipta perdagangan pangan yang jujur dan bertanggung jawab. Beberapa peraturan itu antara lain : PerMenKes No. 23/MenKes/SK/I/1978 tentang pedoman cara produksi pangan yang baik (CPPB) atau good manufacturing practice (GMP); Undang-Undang Kesehatan No. 23 Tahun 1992; PerMenKes No. 722/MenKes/IX/1988 tentang bahan

\section{WILDAN WIBAWA PERDANA}


tambahan pangan (BTP) dan penggunaannya; Pedoman higiene makanan Tahun 1996 (Departemen Kesehatan, 1998); Undang-Undang Pangan RI No. 7 Tahun 1996 tentang keamanan pangan yang tercantum pada pasal 4 sampai dengan pasal 23 (Kantor Menpangan, 1996); dan Peraturam Pemerintah (PP) No.28 Tahun 2004 tentang keamanan pangan, mutu dan gizi pangan (Badan POM, 2004).

Data BPOM (2008) yang menunjukkan bahwa sebagian besar penyakit karena pangan (foodbome diseases) yang disebabkan adanya agen mikrobiologi, sebetulnya mengindikasikan bahwa pengolahan makanan di industri pangan terutama IKM Pangan masih belum memenuhi standar sanitasi dan higiene. Selain itu, industri tersebut belum menerapkan good manufacturing practices (GMP) atau cara pengolahan pangan yang baik (CPPB). Hal ini terlihat dari data BPOM (2007) yang menunjukkan bahwa pada tahun 2007, dari 4.007 sarana produksi yang diperiksa, sebanyak 2.271 $(56,68 \%)$ sarana di antaranya tidak memenuhi ketentuan; sehingga tidak mampu menerapkan GMP (good manufacturing practices) secara konsisten. Bahkan, industri rumah tangga pangan (IRTP) sebesar 75,91\% dari total sarana tidak memenuhi ketentuan.

Menurut Muhandri dan Kadarisman (2006) karakteristik yang harus dipertimbangkan untuk produk olahan pangan yang aman antara lain: mutu bahan baku, metoda proses, kontaminasi pasca proses dan penentuan titik kendali kritis. Unsur-unsur bahaya ini mencakup racun biologis, hasil reaksi kimia serta kontaminasi terhadap fisik pangan.

Hasil penelitian yang dilakukan oleh Sudibyo et al (2001) menunjukkan bahwa dari sebanyak 80 sampel industri pangan yang digunakan dalam penelitian, pada umumnya industri pangan tersebut banyak yang belum menerapkan prinsip-prinsip atau aspek manajemen keamanan pangan yang baik untuk menjamin keamanan pangan produk pangan yang dihasilkannya.

PENERAPAN industri pangan berskala menengah di Indonesia teridentifikasi bahwa program keamanan pangan dan penerapan sistem keamanan pangan ditinjau dari aspek GMP, sanitasi dan higiene, SOP, sistem HACCP dan pelatihan sistem keamanan pangan belum dilaksanakan secara penuh sehingga industri pangan berskala menengah tersebut perlu dibina, diberdayakan dan ditingkatkan kinerjanya dalam bidang keamanan pangan. Dimana menunjukkan bahwa industri pangan yang tidak mempraktekkan atau mengimplementasikan higiene pangan pada perusahaannya mencapai 2-5 kalinya dibandingkan dengan industri kecil pangan yang mempraktekkan/mengimplementasikan higiene pangan.

Menurut Motarjeni et al (1996) dan Stevenson (1990), HACCP merupakan sistem manajemen pengawasan dan pengendalian keamanan pangan secara preventif yang bersifat ilmiah, rasional, sistematis dan komprehensif dengan tujuan mengidentifikasi, memantau atau memonitor dan mengendalikan bahaya mulai dari bahan baku, proses produksi/pengolahan, manufakturing, penanganan dan penggunaan bahan pangan; untuk menjamin bahwa pangan tersebut aman bila dikonsumsi.

Keuntungan dari penerapan sistem HACCP yaitu dapat mengurangi tingkat risiko terhadap morbiditas dan mortalitas yang dikaitkan dengan konsumsi pangan yang tidak aman (Antle, 1999).

Penerapan sistem HACCP sebagai bagian dari sistem manajemen mutu menyeluruh (total quality management) bila diimplementasikan secara tepat dapat memberi keuntungan sebagai berikut : perbaikan dalam efisiensi operasional, mengurangi biaya transaksi dan menciptakan keuntungan yang lebih kompetitif (Farina, 2000).

Menurut Ditjen Pengawasan Obat dan Makanan (1996), dinyatakan bawa tujuan umum HACCP adalah meningkatkan kesehatan masyarakat dengan cara mencegah atau mengurangi 
kasus keracunan dan penyakit melalui pangan, sedang tujuan khusus HACCP adalah : (1) Mengevaluasi cara memproduksi pangan untuk mengetahui bahaya yang mungkin timbul dari makanan, (2) Memperbaiki cara memproduksi pangan dengan memberi perhatian khusus terhadap tahap-tahap proses yang dianggap kritis, (3) Memantau dan mengevaluasi cara-cara penanganan dan pengolahan pangan serta penerapan sanitasi dalam memproduksi pangan, dan (4) Meningkatkan inspeksi mandiri terhadap industri pangan oleh operator dan karyawan. Disamping itu, HACCP sangat berguna bagi industri pangan, yaitu dalam hal : mencegah penarikan produk, mencegah penutupan pabrik, meningkatkan jaminan keamanan produk pangan, pembenahan dan pembersihan pabrik, mencegah kehilangan pembeli atau pasar, meningkatkan kepercayaan konsumen dan mencegah pemborosan biaya atau kerugian yang mungkin timbul karena masalah keamanan produk pangan.

\section{Hipotesis Penelitian}

Berdasarkan kerangka penelitian diatas, maka dapat diambil hipotesis, yang diduga bahwa dengan penerapan HACCP, SSOP, dan GMP dapat meningkatkan kualitas IKM.

\section{Tempat dan Waktu Penelitian}

Penelitian dilakukan di CV. Ruyaprima Utama di Kabupaten Cianjur, mulai bulan Oktober 2013 - sekarang 2014.Analisis secara laboratorium dilakukan di laboratorium Teknologi Pangan Universitas Pasundan Bandung.

\section{METODELOGI PENELITIAN}

\section{Metode Penelitian}

Metode penelitian yang dilakukan dalam penelitian ini meliputi Evaluasi Kondisi Kelayakan Persyaratan Dasar (GMP) di Perusahaan, Penyusunan SSOP (Standard Sanitation Operating Procedure) dan Daftar Isian (checklist), Penyusunan Rencana HACCP (HACCP Plan), dan Analisis Kimia Produk.

\section{Evaluasi Kondisi Kelayakan Persyaratan Dasar (GMP) di Perusahaan Evaluasi GMP yang dilakukan} terdiri dari :

1. Pengumpulan Data Pengumpulan data dilakukan dengan cara sebagai berikut:

a. Studi kepustakaan (literatur), terutama mengenai pengawasan mutu produk dan penerapan GMP; tahapan penyusunan SSOP, dan peraturan yang berkaitan dengan sanitasi produksi.

b. Wawancara terhadap pemilik usaha dan karyawan yang terlibat dalam proses produksi untuk mengetahui sejauh mana pengertian mengenai produk, proses dan pentingnya pengendalian mutu dalam produksi.

c. Mempelajari berbagai dokumen proses produksi yang ada di perusahaan.

d. Pengamatan langsung di area produksi dengan cara mengamati setiap kegiatan produksi.

2. Penilaian Penerapan GMP.

Pelaksanaan penilaian penerapan GMP baik dilakukan dengan tahapan seperti terlihat pada Gambar 8 . 


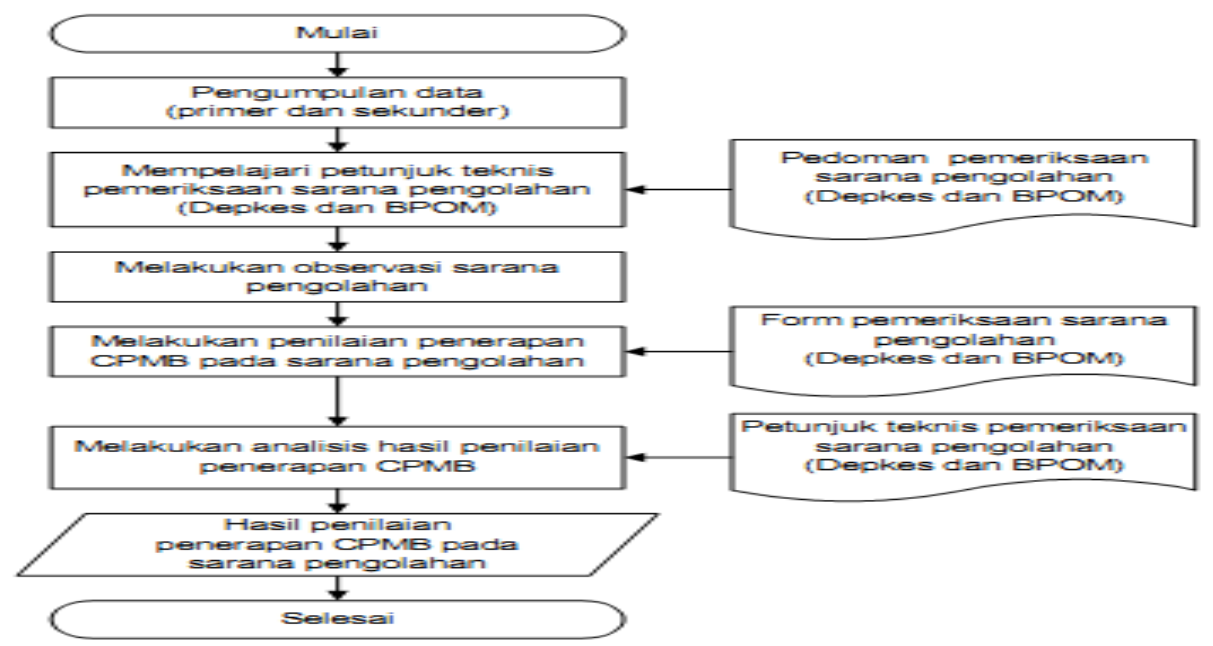

Gambar 3. Diagram alir pelaksanaan penilaian penerapan GMP

Proses penilaian penerapan GMP dengan menggunakan draft revisi formulir pemeriksaan CPMB (BPOM, 2005) dilakukan terhadap 17 aspek pemeriksaan seperti terlihat pada Tabel 2.

Tabel 2. Tujuh belas aspek pemeriksaan sarana produksi menurut draft revisi formulir pemeriksaan CPMB (BPOM, 2005)

\begin{tabular}{|c|c|c|c|c|}
\hline \multicolumn{2}{|c|}{ Kelompok } & No & Aspek & Keterangan \\
\hline \multirow{2}{*}{ I } & \multirow{2}{*}{$\begin{array}{l}\text { Ketentuan } \\
\text { Umum }\end{array}$} & 1 & $\mathrm{~A}$ & Persepsi pimpinan dan manajemen \\
\hline & & 2 & $\mathrm{~B}$ & Sanitasi dan higiene karyawan \\
\hline \multirow{11}{*}{ II } & \multirow{11}{*}{$\begin{array}{l}\text { Kondisi } \\
\text { sanitasi } \\
\text { bangunan } \\
\text { dan fasilitas }\end{array}$} & 3 & $\mathrm{C}$ & Konstruksi dan desain bangunan - umum \\
\hline & & 4 & $\mathrm{D}$ & Konstruksi dan desain ruang pengolahan \\
\hline & & 5 & $\mathrm{E}$ & Kondisi gudang biasa (kering) \\
\hline & & 6 & $\mathrm{~F}$ & $\begin{array}{l}\text { Kondisi gudang beku, dingin (apabila } \\
\text { digunakan) }\end{array}$ \\
\hline & & 7 & G & Kondisi gudang kemasan dan produk \\
\hline & & 8 & $\mathrm{H}$ & $\begin{array}{l}\text { Sanitasi lingkungan: lokasi, pembuangan limbah, } \\
\text { investasi burung, serangga, atau binatang lain }\end{array}$ \\
\hline & & 9 & $\mathrm{I}$ & Fasilitas pabrik \\
\hline & & 10 & $\mathrm{~J}$ & Pasokan air \\
\hline & & 11 & $\mathrm{~K}$ & Operasional sanitasi pabrik \\
\hline & & 12 & $\mathrm{~L}$ & $\begin{array}{l}\text { Pencegahan binatang pengganggu/ } \\
\text { serangga dalam pabrik }\end{array}$ \\
\hline & & 13 & $\mathrm{M}$ & Penggunaan bahan kimia \\
\hline \multirow[b]{2}{*}{ III } & \multirow{2}{*}{$\begin{array}{l}\text { Kondisi } \\
\text { dan sanitasi } \\
\text { peralatan }\end{array}$} & 14 & $\mathrm{~N}$ & Peralatan produksi \\
\hline & & 15 & $\mathrm{O}$ & $\begin{array}{l}\text { Penanganan bahan baku dan bahan } \\
\text { Tambahan }\end{array}$ \\
\hline \multirow[b]{2}{*}{ IV } & \multirow{2}{*}{$\begin{array}{l}\text { Produksi } \\
\text { dan } \\
\text { Pengendali } \\
\text { an proses }\end{array}$} & 16 & $\mathrm{P}$ & Pengendalian proses produksi \\
\hline & & 17 & Q & Tindakan pengawasan \\
\hline
\end{tabular}




\section{Penyusunan SSOP (Standard Sanitation Operating Procedure) dan Daftar Isian} (checklist)

SSOP dan daftar isian disusun Diagram alir penyusunan SSOP dapat berdasarkan hasil identifikasi tersebut. dilihat pada Gambar 9.

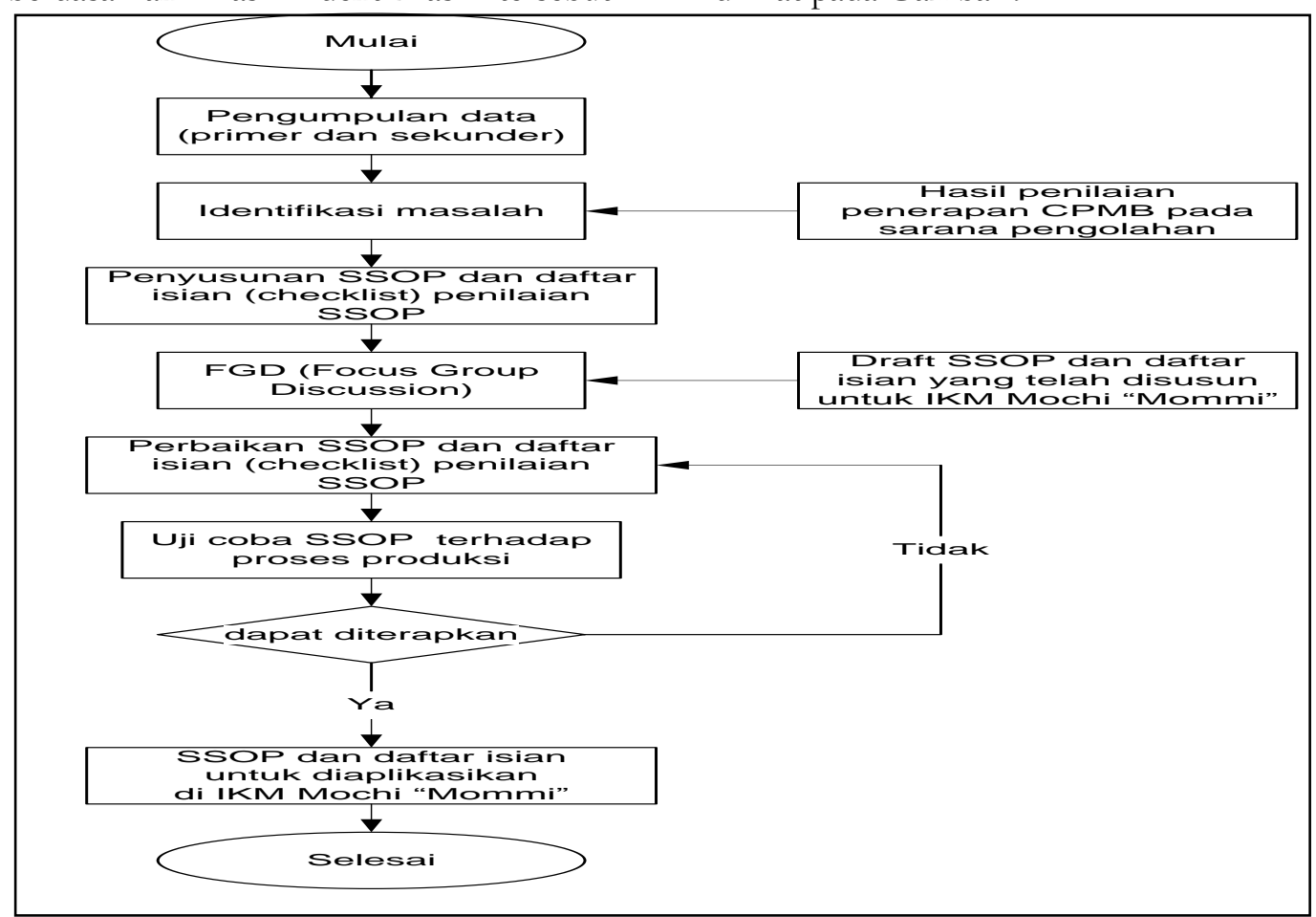

Gambar 4. Diagram alir penyusunan SSOP dan daftar isian

\section{Penyusunan Rencana HACCP (HACCP Plan) \\ Penyusunan rencana HACCP} (HACCP Plan) untuk produksi IKM mochi "Momi" dilakukan dengan tahapan sebagai berikut :

a. Pembentukan Organisasi Tim HACCP

Pembentukan organisasi tim HACCP meliputi : identitas dan kualifikasi personil yang dibentuk, uraian tugas, tanggung jawab dan wewenang tim HACCP, serta prosedur yang terkait yang menunjukkan personil yang bertanggung jawab terhadap pengembangan, penerapan dan berjalannya Rencana HACCP atau HACCP Plan perusahaan.

b. Deskripsi Produk
Tim HACCP yang telah dibentuk kemudian menyusun deskripsi atau uraian dari produk pangan yang akan disusun rencana HACCP. Deskripsi produk yang dilakukan berupa keterangan lengkap mengenai produk, termasuk jenis produk, komposisi, formulasi, proses pengolahan, daya simpan, cara distribusi, serta keterangan lain yang berkaitan dengan produk. Semua informasi tersebut diperlukan Tim HACCP untuk melakukan evaluasi secara luas dan komprehensif.

c. Identifikasi produk

Deskirpsi produk hasil studi HACCP di Perusahaan dapat dilihat pada Tabel 3. 
Tabel 3. Deskripsi produk

\begin{tabular}{|l|l|}
\hline \multicolumn{1}{|c|}{ Produk } & \multicolumn{1}{c|}{ Mochi } \\
\hline $\begin{array}{l}\text { Komposisi } \\
\text { Utama } \\
\text { Penunjang }\end{array}$ & $\begin{array}{l}\text { Tepung ketan, air, pewarna makanan } \\
\text { Kacang tanah, gula pasir, tepung kanji }\end{array}$ \\
\hline Kemasan Primer & Box beralas plastik \\
\hline $\begin{array}{l}\text { Kondisi } \\
\text { penyimpanan }\end{array}$ & $\begin{array}{l}\text { Produk akhir disimpan pada rsuhu ruangan, atau dapat disimpan pada suhu } \\
\text { chiller }\left(10{ }^{\circ} \mathrm{C}\right) \text { dan tetap dikemasan primer }\end{array}$ \\
\hline Metode Distribusi & Didistribusikan langsung ke konsumen (konsumen datang langsung ke gerai) \\
\hline Shelf life & $\begin{array}{l}\text { Produk akhir memiliki shelf life } 6 \text { hari, selama } \\
\text { disimpan pada suhu } 10^{\circ} \mathrm{C}\end{array}$ \\
\hline Konsumen & Anak-anak hingga orang tua \\
\hline & \\
\hline
\end{tabular}

d.Penyusunan diagram alir proses

Dengan dususunnya diagram alir akan mempermudah pemantauan selama proses produksi mochi dan mempermudah penetapan CCP. Bagan alir proses dapat dilihat pada Gambar 10.

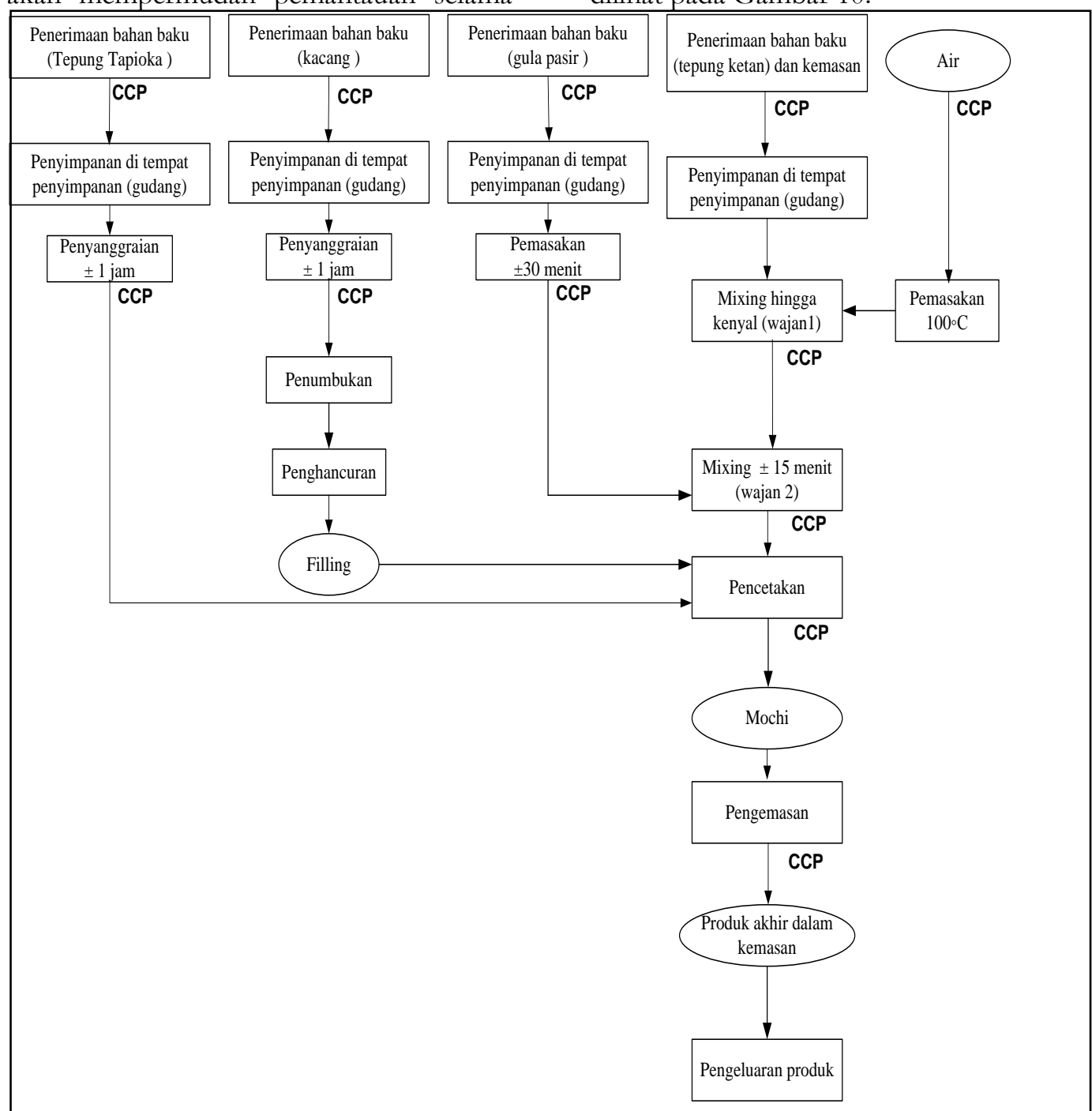

Gambar 5. Diagram alir penentuan titik kritis (CCP) proses produksi mochi.

\section{PENERAPAN

WILDAN WIBAWA PERDANA 
e. Verifikasi Diagram Alir Proses

Agar diagram alir proses yang dibuat lebih lengkap dan sesuai dengan pelaksanaan di lapangan, maka tim HACCP harus meninjau operasinya untuk menguji dan membuktikan ketepatan serta kesempurnaan diagram alir proses tersebut. Bila ternyata diagram alir proses tersebut tidak tepat atau kurang sempurna, maka harus dilakukan modifikasi. Diagram alir proses yang telah dibuat dan diverifikasi harus didokumentasikan.

f. Identifikasi bahaya dan cara pencegahan (prinsip 1)

Analisis bahaya terdiri dari tiga tahap yaitu, identifikasi bahaya, penetapan tindakan pencegahan (preventive measure), dan penentuan kategori resiko atau signifikansi suatu bahaya. Bahaya-bahaya dapat dikategorikan ke dalam enam kategori bahaya, yaitu bahaya A sampai F .

Tabel 4. Jenis-Jenis Bahaya

\begin{tabular}{|c|c|}
\hline Jenis Bahaya & Contoh \\
\hline Biologi & Sel Vegetatif : Salmonella sp, Escherichia coli \\
\hline & Kapang : Aspergillus, Penicillium, Fusarium \\
\hline & : Hepatitis A \\
\hline & : Cryptosporodium sp \\
\hline & Spora bakteri : Clostridium botulinum, Bacillus cereus \\
\hline Kimia & $\begin{array}{l}\text { Toksin mikroba, bahan tambahan yang tidak diizinkan, residu pestisida, logam } \\
\text { berat, bahan allergen }\end{array}$ \\
\hline Fisik & $\begin{array}{l}\text { Pecahan kaca, potongan kaleng, ranting kayu, batu atau kerikil, rambut, kuku, } \\
\text { perhiasan }\end{array}$ \\
\hline
\end{tabular}

Tabel 5. Karakteristik Bahava

\begin{tabular}{|c|l|}
\hline Kelompok Bahaya & \multicolumn{1}{|c|}{ Karakteristik Bahaya } \\
\hline Bahaya A & $\begin{array}{l}\text { Produk-produk pangan yang tidak steril dan dibuat untuk konsumsi } \\
\text { kelompok beresiko (lansia, bayi, immunocompromised) }\end{array}$ \\
\hline Bahaya B & $\begin{array}{l}\text { Produk mengandung ingridient sensitif terhadap bahaya biologi, kimia } \\
\text { atau fisik }\end{array}$ \\
\hline Bahaya C & $\begin{array}{l}\text { Proses tidak memiliki tahap pengolahan yang terkendali yang secara } \\
\text { efektif membunuh mikroba berbahaya atau menghilangkan bahaya kimia } \\
\text { atau fisik }\end{array}$ \\
\hline Bahaya D & $\begin{array}{l}\text { Produk mungkin mengalami rekontaminasi setelah pengolahan sebelum } \\
\text { pengemasan }\end{array}$ \\
\hline Bahaya E & $\begin{array}{l}\text { Ada potensi terjadinya kesalahan penanganan selama distribusi atau } \\
\text { oleh konsumen yang menyebabkan produk berbahaya }\end{array}$ \\
\hline Bahaya F & $\begin{array}{l}\text { Tidak ada tahap pemanasan akhir setelah pengemasan atau ditangan } \\
\text { kosumen atau tidak ada pemanasan akhir atau tahap pemusnahan } \\
\text { mikroba setelah pengemasan sebelum memasuki pabrik (untuk bahan } \\
\text { baku) atau tidak ada cara apapun bagi } \\
\text { konsumen untuk mendeteksi, menghilangkan atau menghancurkan bahaya } \\
\text { kimia atau fisik }\end{array}$ \\
\hline
\end{tabular}

Untuk menentukan resiko atau peluang tentang terjadinya suatu bahaya, maka dapat dilakukan penetapan kategori resiko. Dari beberapa banyak bahaya yang dimiliki oleh suatu bahan baku, maka dapat diterapkan kategori resiko I sampai VI (Tabel 6). Selain itu, bahaya yang ada dapat juga dikelompokkan

PENERAPAN PERENCANAAN berdasarkan signifikansinya (Tabel 7). Signifikansi bahaya dapat diputuskan oleh tim dengan mempertimbangkan peluang terjadinya (reasonably likely to occur) dan keparahan (severity) suatu bahaya. 
Tabel 6 Penetapan Kategori resiko

\begin{tabular}{|l|l|l|}
\hline \multicolumn{1}{|c|}{ Karakteristik Bahaya } & \multicolumn{1}{c|}{ Kategori Resiko } & \multicolumn{1}{c|}{ Jenis Bahaya } \\
\hline 0 & O & Tidak mengandung bahaya A sampai F \\
\hline$(+)$ & I & Mengandung satu bahaya B sampai F \\
\hline$(++)$ & II & Mengandung dua bahaya B sampai F \\
\hline$(+++)$ & III & Mengandung tiga bahaya B sampai F \\
\hline$(++++)$ & IV & Mengandung empat bahaya B sampai F \\
\hline$(+++++)$ & V & Mengandung lima bahaya B sampai F \\
\hline $\begin{array}{l}\text { A }+ \text { (kategori khusus) dengan } \\
\text { atau tanpa bahaya B-F }\end{array}$ & VI & $\begin{array}{l}\text { Kategori resiko paling tinggi (semua } \\
\text { produk yang mempunyai bahaya A) }\end{array}$ \\
\hline
\end{tabular}

Tabel 7. Signifikansi Bahaya

\begin{tabular}{|l|l|l|l|l|}
\hline \multirow{2}{*}{} & & \multicolumn{3}{|c|}{ Tingkat Keparahan (Severity) } \\
\cline { 3 - 5 } & & $\mathrm{L}$ & $\mathrm{M}$ & $\mathrm{H}$ \\
\hline $\begin{array}{l}\text { PeluangTerjadi } \\
\text { (Reasonably likely to occur) }\end{array}$ & $\mathrm{L}$ & $\mathrm{Ll}$ & $\mathrm{Ml}$ & $\mathrm{Hi}$ \\
\cline { 2 - 5 } & $\mathrm{M}$ & $\mathrm{Lm}$ & $\mathrm{Mm}$ & $\mathrm{Hm}$ \\
\cline { 2 - 5 } & $\mathrm{h}$ & $\mathrm{Lh}$ & $\mathrm{Mh}$ & $\mathrm{Hh}$ \\
\hline
\end{tabular}

Umumnya dianggap signifikan dan akan diteruskan/dipertimbangkan dalam penetapan CCP.

Keterangan : $\mathrm{L}=\mathrm{l}=$ low, $\mathrm{M}=\mathrm{m}=$ medium, $\mathrm{H}=\mathrm{h}=$ high

g. Penetapan CCP (prinsip 2)

Setiap titik penerapan tindakan pencegahan vang telah ditetapkan diujidengan menggunakan CCP decision tree atau diagram pohon penentuan CCP.

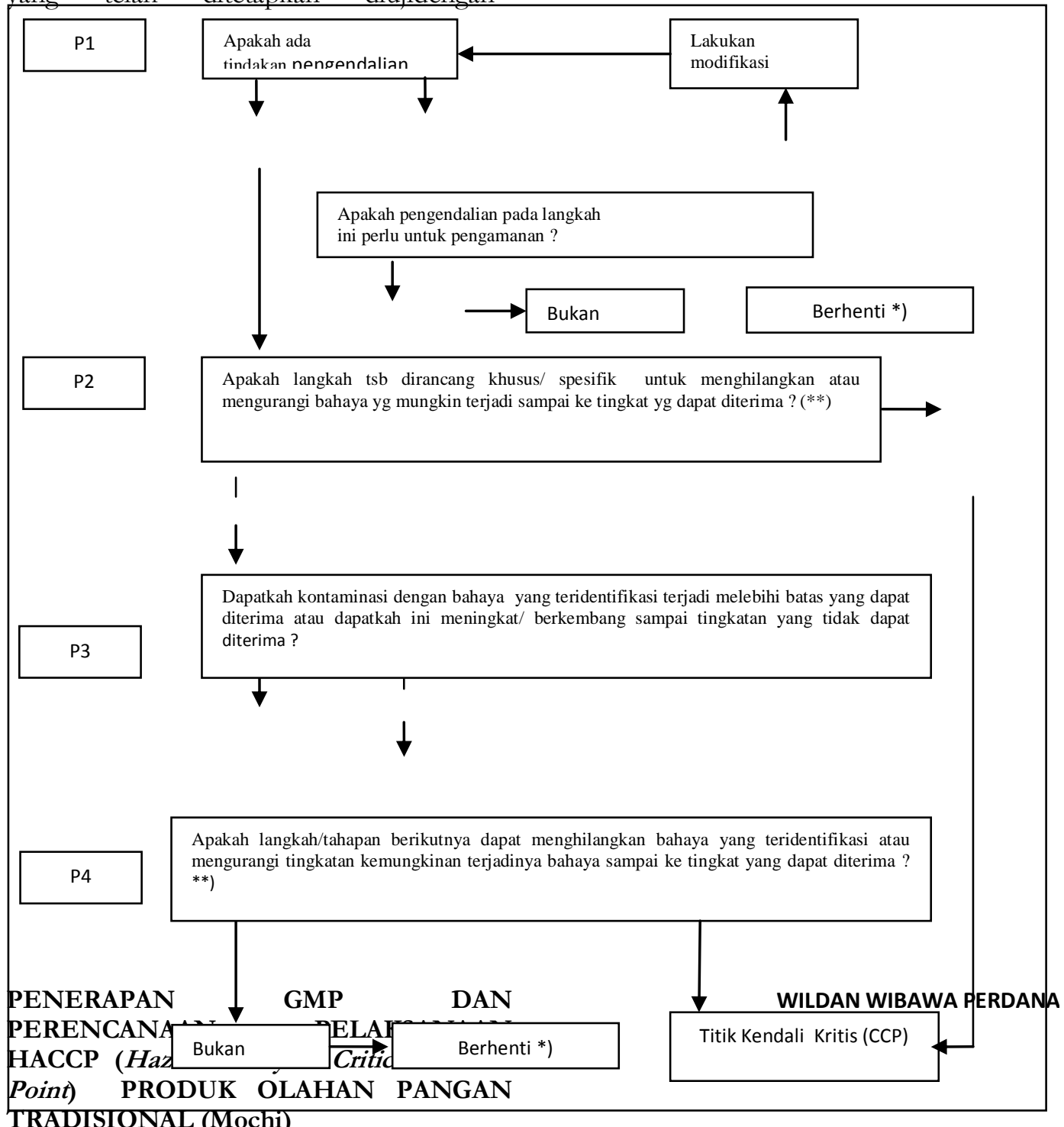

TRADISIONAL (Mochi) 
* ) Identifikasi bahaya dalam menggambarkan proses

** ) Tingkatan yang dapat diterima \& tidak dapat diterima yang diperlukan didefinisikan dalam semua tujuan mengidentifikasi CCP dalam rencana HACCP

Gambar 6. Diagram alir pohon penentuan titik kendali kritis atau CCP untuk pengembangan HACCP Plan di IKM Mochi Mommi.

h. Penetapan batas kritis (prinsip 3)

Secara umum batas kritis dapat digolongkan ke dalam batas fisik (suhu, waktu), batas kimia (pH).

Tabel 8. Contoh Critical Limit (Batas Kritis) Pada CCP

\begin{tabular}{|l|l|}
\hline CCP & Komponen Kritis \\
\hline Penyanggraian Tepung Tapioka dan kacang Tanah & $\begin{array}{l}\text { Suhu awal } \\
\text { Waktu pemanasan } \\
\text { Pengadukan Bahan }\end{array}$ \\
\hline Pemasakan Gula Pasir & $\begin{array}{l}\text { Suhu pemanasan } \\
\text { Waktu pemanasan } \\
\text { Pengadukan Bahan }\end{array}$ \\
\hline Pencampuran I & $\begin{array}{l}\text { Suhu Air } \\
\text { Jumlah Air } \\
\text { Pengadukan Bahan }\end{array}$ \\
\hline Pencampuran II & Jumlah Gula dengan \\
& Adonan \\
\hline Pencetakan Produk & Ukuran Mochi \\
& Penambahan Tepung \\
& Tapioka \\
\hline Pengemasan Produk & Pemeriksaan Kemasaan \\
& Penentuan Expire date \\
\hline
\end{tabular}

i. Penetapan tindakan pemantauan (prinsip 4)

Tindakan pencegahan yang telah teratur, terutama untuk tindakan pencegahan bahaya kritis.

dilakukan harus dimonitoring secara

Tabel 9. Contoh Formulir/Lembar Kertas Kerja Untuk Pengendalian dan Pemantauan Rencana HACCP (HACCP Plan) pada Perusahaan yang akan Menerapkan Sistem HACCP

\begin{tabular}{|c|c|c|c|c|c|c|c|c|c|c|}
\hline \multirow[t]{2}{*}{$\mathrm{CCP}$} & \multirow{2}{*}{$\begin{array}{l}\text { Tahap } \\
\text { Proses }\end{array}$} & \multirow{2}{*}{$\begin{array}{l}\text { Bahaya yg } \\
\text { signifikan } \\
\text { terdidentifi } \\
\text { kasi }\end{array}$} & \multirow{2}{*}{$\begin{array}{l}\text { Batas } \\
\text { Kritis } \\
\text { Kegiatan }\end{array}$} & \multicolumn{4}{|c|}{ Pemantauan/Monitoring } & \multirow{2}{*}{$\begin{array}{l}\text { Tinda } \\
\text { kan } \\
\text { Korek } \\
\text { si }\end{array}$} & \multirow{2}{*}{$\begin{array}{l}\text { Tindakan } \\
\text { Verifikasi }\end{array}$} & \multirow{2}{*}{$\begin{array}{l}\text { Rekaman } \\
\text { (Record) }\end{array}$} \\
\hline & & & & Apa & Bagaimana & Kapan & Siapa & & & \\
\hline & & & & & & & & & & \\
\hline & & & & & & & & & & \\
\hline & & & & & & & & & & \\
\hline
\end{tabular}

j. Penetapan tindakan koreksi (prinsip 5)

Tindakan koreksi yang telah dilakukan kemudian dicatat. Tindakan koreksi yang dilakukan bisa berupa :

1. Pengulangan pencucian peralatan.

2. Mereject produk jika penyimpanan yang terjadi memberikan dampak negatif terhadap kesehatan konsumen atau tidak

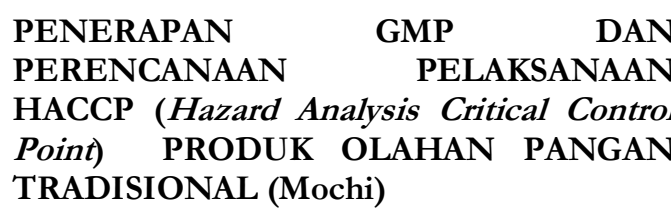

digunakan rework yang mengandung allergen.

k. Penetapan prosedur pencatatan yang efektif (prinsip 6)

Dokumentasi harus dapat mencakup data-data teknis hasil studi yang meliputi :

1. Bahan baku dan bahayanya

2. Resiko bahaya atau keamanan produk 
3. Tahapan proses dan kemungkinan bahayanya

4. Titik kendali kritis (CCP)

5. Batas kritis terhadap penyimpangan

6. Tindakan koreksi

7. Modifikasi sistem HACCP

k. Penetapan prosedur verifikasi (prinsip 7) Tahapan yang umum dilakukan untuk melaksanakan verifikasi system HACCP adalah :

1. Review rencana HACCP

2. Kesesuaian dengan titik kendali kritis (CCP) yang sudah ditetapkan

3. Konfirmasi kesesuaian prosedur penanganan deviasi dan rekaman

4. Inspeksi visual proses produksi

5. Penulisan laporan

1. Perekaman Data (Dokumentasi)

Dokumentasi program HACCP

meliputi pendataan tertulis seluruh program HACCP sehingga program tersebut dapat diperiksa ulang dan dipertahankan selama periode waktu tertentu. Dokumentasi mencakup semua catatan mengenai CCP, CL, rekaman pemantauan CL, tindakan koreksi yang dilakukan terhadap penyimpangan, catatan tentang verifikasi dan sebagainya. Oleh karena itu dokumen ini dapat ditunjukkan kepada inspektur pengawas makanan jika dilakukan audit eksternal dan dapat juga digunakan oleh operator.

\section{Bahan dan Alat Penelitian}

\section{Bahan-Bahan yang Digunakan}

Bahan-bahan yang digunakan adalah produk mochi dari IKM mochi "Mommi" sebagai sampel pengujian di laboratorium yang sudah terakreditasi, identifikasi dan analisis bahaya, verifikasi dan validasi sistem HACCP, serta mengetahui sesuai dengan SNI yang berlaku atau tidak.

Bahan-bahan yang digunakan untuk analisis kimia adalah $\mathrm{HCl} 25 \%$, aquadest, $\mathrm{H}_{2} \mathrm{SO}_{4} 6 \mathrm{~N}, \mathrm{KI}, \mathrm{Na}_{2} \mathrm{~S}_{2} \mathrm{O}_{3} 0,1 \mathrm{~N}$,
HCL 25\%, $\mathrm{NaOH} 30 \%, \mathrm{H}_{2} \mathrm{SO}_{4} 6 \mathrm{~N}$, amilum $1 \%, \mathrm{KIO}_{3}, \mathrm{Na}_{2} \mathrm{SO}_{4}$ anhidrat, $\mathrm{HgO}$, selenium black, $\mathrm{H}_{2} \mathrm{SO}_{4}$ pekat, $\mathrm{Na}_{2} \mathrm{~S}_{2} \mathrm{O}_{3} 5 \%$, granul $\mathrm{Zn}, \mathrm{HCl} 0,1 \mathrm{~N}$ baku, $\mathrm{Na}_{2} \mathrm{SO}_{4}$ anhidrat, 0,7 g HgO, 0,2g selenium black, $\mathrm{NaOH} 0,1 \mathrm{~N}$ baku, dan fenolphtalein.

\section{Alat-Alat yang Digunakan}

Alat-alat yang digunakan dalam analisis kimia diantaranya adalah pipet ukur, timbangan digital, erlenmeyer, kaca arloji, oven, kertas saring, kertas lakmus, eksikator, labu takar, cawan penguap, labu kjedahl, kompor, kondensor, buret, ruang asam, dan corong.

\section{Analisis}

Analisis yang akan dilakukan pada penelitian ini meliputi

1. Analisis bahan baku

a. Tepung Ketan : analisis yang dilakukan yaitu analisis Cemaran Fisik, Kimia dan Mikroba.

b. Kacang Tanah : analisis yang dilakuakan yaitu analisis fisik secara visual.

c. Gula : analisis yang dilakukan yaitu analisis Cemaran Fisik, Kimia dan Mikroba..

d. Air : analisis yang dilakuakan yaitu analisis fisik dengan penentuan aroma,rasa, warna a analisis kimia dengan penetuan logam berat dan analisis mikrobiologi dengan pengujian Total Bakteri atau Total Plate Count (TPC) dan E.coli

e. Analisis Produk

Analisis produk yang dilakukan dalam penelitian ini adalah analisis secara Analisis Proksimat dan ana;isis kandungan Total Bakteri atau Total Plate Count (TPC)yang bertujuan untuk mengidentifikasi kandungan zat dan kandungan bakteri dalam makanan yang belum diketahui sebelumnya.
WILDAN WIBAWA PERDANA 


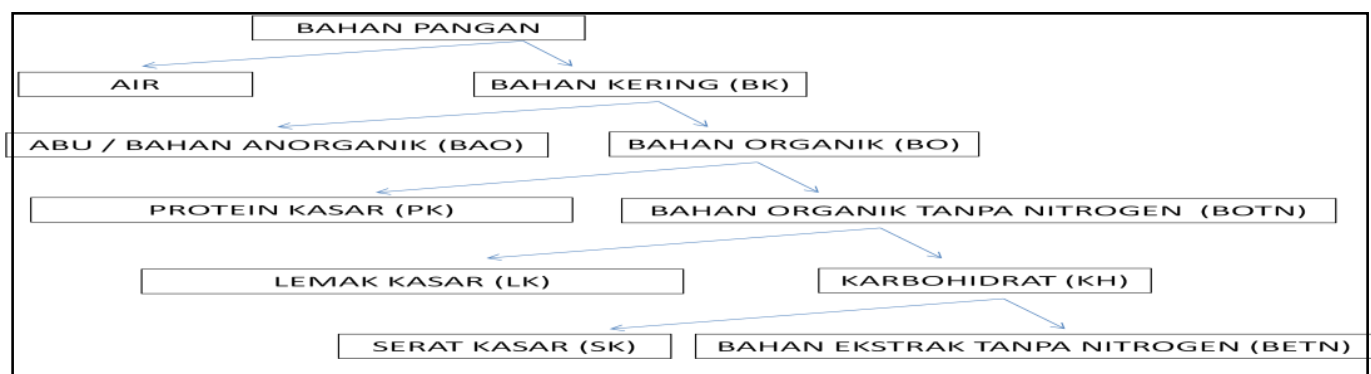

Gambar 7. Bagan Fraksi Analisis Proksimat

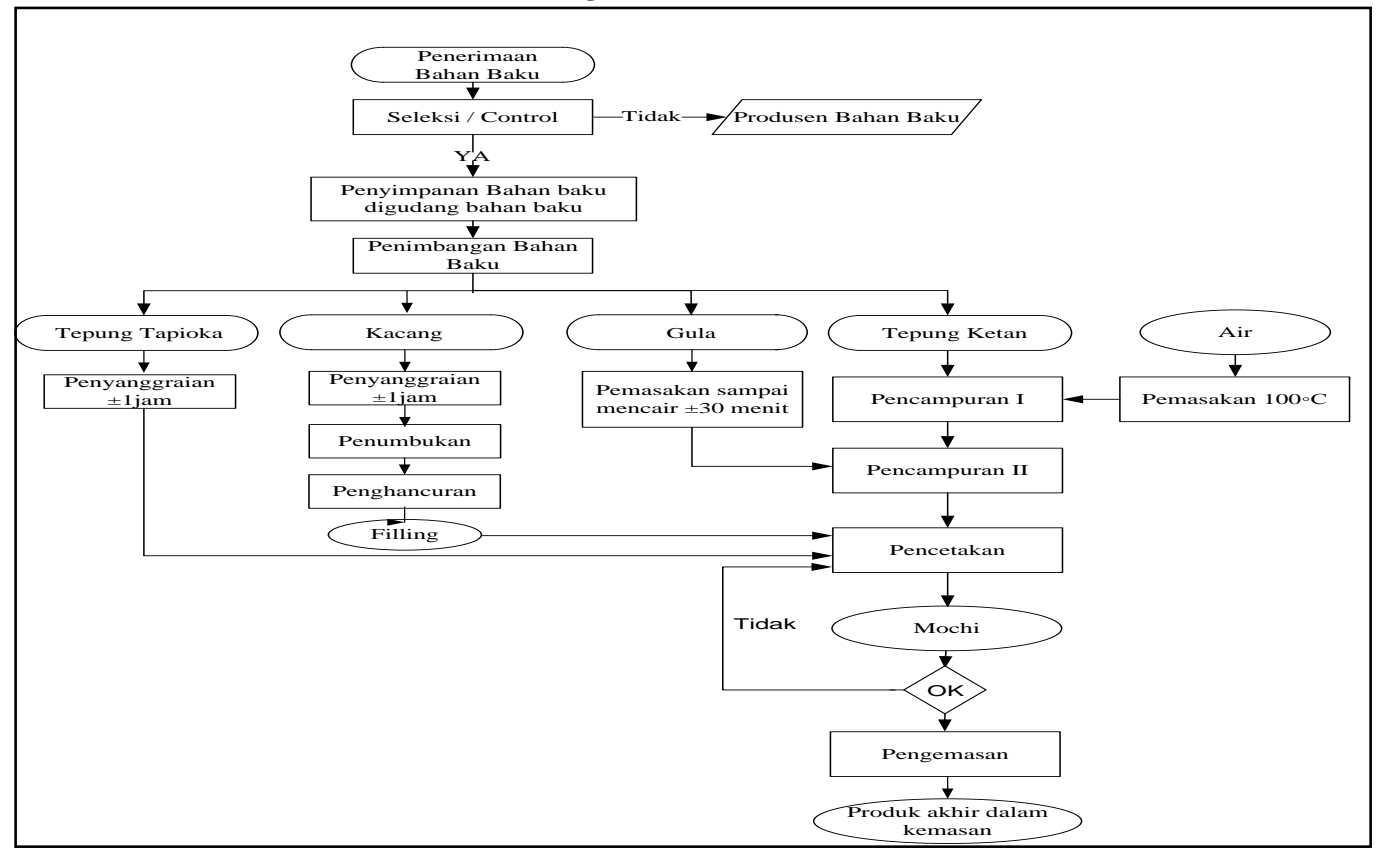

Gambar 8. Diagram Alir Proses Pembuatan Mochi

\section{HASIL DAN PEMBAHASAN}

Evaluasi dan Kelayakan Persyaratan Dasar Berdasarkan GMP di CV. Ruyaprima Utama

Penerapan sistem manajemen keamanan pangan berdasarkan sistem HACCP di perusahaan akan berjalan dengan sukses apabila penerapan good manufacturing practice (GMP) sebagai dasar sistem manajemen keamanan pangan berdasarkan sistem HACCP ini telah berjalan dengan efektif. Oleh karena itu, sebelum dilakukan penerapan dan pengembangan sistem manajemen keamanan pangan berdasarkan/berbasis sistem HACCP, akan lebih baik jika diterapkan GMP terlebih dahulu dan dilakukan evaluasi yang akan dibandingkan dengan standar penerapan GMP yang ada,

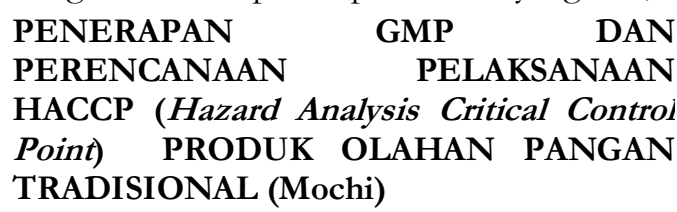

PENERAPAN PERENCANAAN

GMP PELAKSANAAN HACCP (Hazard Analysis Critical Contro Point) PRODUK OLAHAN PANGAN TRADISIONAL (Mochi)

yaitu standar GMP dari Badan Pengawas Obat dan Makanan (BPOM) tahun 2004.

Berdasarkan pengamatan (observasi) yang dilakukan di lapangan, wawancara dan pengamatan keadaan nyata perusahaan atas penerapan GMP di CV. Ruyaprima Utama dibandingkan dengan standar yang ada (berdasarkan kriteria penilaian yang digunakan BPOM tahun 2004) ditemukan 9 penyimpangan; yaitu 6 penyimpangan mayor dan 3 penyimpangan minor.Hasil selengkapnya dari pemeriksaan GMP sarana produksi pangan di CV. Ruyaprima Utama dapat dilihat pada Lampiran 6.Hasil identifikasi dan ketigabelas hasil penyimpangan atau ketidak-sesuaian tersebut dapat dikelompokkan dalam unsur-unsur GMP yang disajikan pada Tabel 10.

\section{WILDAN WIBAWA PERDANA}


Tabel 10. Hasil Identifikasi Penyimpangan/Ketidaksesuaian Dalam Penerapan Unsur-Unsur GMP di Perusahaan.

\begin{tabular}{|c|c|c|c|}
\hline No & $\begin{array}{l}\text { Unsur/Elemen } \\
\text { GMP }\end{array}$ & Penyimpangan/Ketidaksesuaian & Kategori \\
\hline 1. & Bangunan & $\begin{array}{l}\text { - Pertemuan antara lantai dan dinding serta antara } \\
\text { dinding dengan dinding berbentuk siku, sehingga hal ini } \\
\text { tidak mudah untuk pembersihan bila ada deposit } \\
\text { kotoran, } \\
\text { - Rancang bangun untuk pabrik, khususnya dengan disain } \\
\text { penutup (plastik) sebagai pembatas antara tempat } \\
\text { pengolahan dan tempat pencetakan untuk perlindungan } \\
\text { pada proses produksi untuk mencegah adanya } \\
\text { kontaminasi silang. }\end{array}$ & Minor \\
\hline 2. & Fasilitas Sanitasi & $\begin{array}{l}\text { Sebagian tempat sampah yang disediakan oleh IKM tidak } \\
\text { ada penutupnya, sehingga dapat berpotensi menimbulkan } \\
\text { adanya kontaminasi silang. }\end{array}$ & Minor \\
\hline 3. & Higiene Karyawan & $\begin{array}{l}\text { - Manajemen unit pengolahan tidak memiliki tindakan } \\
\text { efektif untuk mencegah karyawan yang diketahui } \\
\text { mengidap penyakit yang dapat mengkontaminasi produk } \\
\text { - Kebersihan karyawan tidak terjaga dengan baik dan } \\
\text { kurang memperhatikan aspek sanitasi dan hygiene } \\
\text { (misalnya pakaian seragam celemek ada yang kotor, } \\
\text { kebiasaan minum di ruang produksi). }\end{array}$ & $\begin{array}{l}\text { Mayor } \\
\text { Mayor }\end{array}$ \\
\hline 4. & Penyimpanan & $\begin{array}{l}\text { Di ruang gudang biasa/kering ditemukan adanya } \\
\text { penempatan barang yang tidak teratur dan tidak } \\
\text { memisahkan penyimpanan bahan pangan dan bahan non- } \\
\text { pangan }\end{array}$ & Mayor \\
\hline 5. & $\begin{array}{l}\text { Pemeliharaan } \\
\text { Sarana Pengolahan } \\
\text { dan Sanitasi serta } \\
\text { Pengendalian Hama }\end{array}$ & $\begin{array}{l}\text { Pest control hingga saat ini dikerjakan oleh perusahaan } \\
\text { sendiri }\end{array}$ & Mayor \\
\hline 6. & $\begin{array}{l}\text { Manajemen dan } \\
\text { Pelatihan }\end{array}$ & $\begin{array}{l}\text { - Pimpinan/pihak manajemen mempunyai wawasan } \\
\text { terhadap metode pengawasan (GMP, HACCP, dan lain- } \\
\text { lain), tetapi belum melaksanakan penerapannya dalam } \\
\text { perusahaan; } \\
\text { - Alasan belum melaksanakan penerapan HACCP di } \\
\text { IKM adalah HACCP cukup rumit dan perlu persiapan } \\
\text { waktu, tenaga dan sumber daya lain. }\end{array}$ & Mayor \\
\hline
\end{tabular}

Penyimpangan / ketidaksesuaian pertama dan kedua, adalah saling terkait dan berhubungan dengan persyaratan bangunan serta berkaitan dengan upaya untuk mencegah adanya kontaminasi silang yang disebabkan oleh keadaaan lingkungan perusahaan/pabrik (BPOM, 2004)

Penyimpangan/ketidaksesuaian minor adalah kekurangan dalam taraf

rendah sehingga masih mudah untuk memperbaikinya.

Penyimpangan/ketidaksesuaian

ketiga, berhubungan dengan persyaratan fasilitas sanitasi, serta beraitan dengan

\footnotetext{
PENERAPAN PERENCANAAN

GMP DAN Point) PRODUK OLAHAN PANGAN TRADISIONAL (Mochi)
}

upaya untuk mencegah adanya kontaminasi silang yang disebabkan oleh kebersihan dan kesehatan karyawan. Hal ini berkaitan pula dengan program persyaratan dasar (prerequisite programs) sebelum menerapkan manajemen keamanan pangan berdasarkan sistem HACCP.

Penyimpangan keempat dan kelima merupakan hal yang berkaitan yaitu berkaitan dengan upaya untuk mencegah adanya kontaminasi silang yang disebabkan oleh status kesehatan karyawan, kebersihan karyawan, dan kebiasaan karyawan (Higiene Karyawan).Penyimpangan/ketidaksesuaian 
Higiene Karyawan merupakan penyimpangan yang sangat penting yang perlu segera diatasi dan diprogramkan implementasinya sebelum diterapkannya sistem manajemen kemanan pangan berdasarkan sistem HACCP; mengingat pengendalian kondisi kesehatan karyawan yang berpotensi menghasilkan kontaminasi mikrobiologis terhadap pangan, bahan kemasan pangan dan permukaan yang kontak dengan pangan ini harus dikendalikan dengan baik melalui program penerapan yang efektif.

Penyimpangan

keenam, berhubungan dengan aspek GMP penyimpanan, yaitu di gudang kering, yang mana penempatan barang tidak teratur dan sebagian tidak dipisahkan (penyimpanan bahan pengemas dan bahan-bahan lain, bahan kimia dan desinfektan/deterjen), hal ini dapat segera diatasi dengan mengelompokkan atau memisahkan sesuai dengan jenisnya dalam suatu rak/tempat yang terpisah dan khusus untuk jenis barang-barang tersebut. Pengaturan ini perlu dibakukan dan dilaksanakan/ dijalankan secara konsisten.

Penyimpangan/ketidaksesuaian

mayor adalah Kekurangan sudah mendekati/mengarah pada hal-hal serius yang dapat mengakibatkan terjadinya kemunduran mutu (BPOM, 2004).

Menurut Ditjen POM, tujuan penerapan GMP adalah menghasilkan produk akhir pangan yang bermutu, aman dikonsumsi, dan sesuai dengan selera atau tuntutan konsumen, baik konsumen domestik maupun internasional. $\mathrm{Hal}$ tersebut mengacu pada hasil observasi dari perusahaan, selain ditemukan penyimpangan mayor dan minor ,juga ditemukan penyimpangan lain dalam bentuk administrasi, fisik dan oprasional sebagai berikut :

a. Spesifikasi bahan baku, bahan penolong dan bahan tambahan pangan belum diterapkan secara konsisten karena standar persyaratan spesifikasi yang ditetapkan perusahaan masih suka berubah, oleh karena itu perlu ditetapkan standar persyaratan spesifikasi bahan-bahan tersebut yang tetap dan konsisten penerapannya,

b. Pada higiene karyawan ditemukan kekurangan dalam pelaksanaan GMP pada saat produksi, antara lain masih adanya karyawan yang menggunakan perhiasan atau jam tangan pada waktu bekerja, penutup kepala yang dipakai tidak menutup seluruh rambutnya, masih ada karyawan yang menggunakan celemek yang agak kotor, dan masih ada karyawan berbicara pada saat berproduksi serta tidak memakai penutup mulut,

c. Kondisi sanitasi di ruang/gudang penyimpanan bahan baku tepung terigu saat diobservasi/diinspeksi kurang bersih dan kurang terkontrol. Cukup banyak debu dan tepung yang berceceran pada lantai dan dindingnya. Kemungkinan kegiatan sanitasi di gudang penyimpanan bahan baku tepung ini belum terjadwal dan terkontrol dengan baik.

Sanitation standard operating procedure (SSOP) ini akan memberikan manfaat bagi unit usaha perusahaan CV. Ruyaprima Utama dalam menjamin sistem keamanan produksi pangannya, antara lain : (a) Memberi jadwal pada prosedur sanitasi, (b) Memberikan landasan program monitoring berkesinambungan, (c) Menjamin setiap personil mengerti sanitasi, (d) Memberikan sarana pelatihan yang konsisten bagi personil, (e) Mendorong perencanaan yang menjamin dilakukan koreksi bila diperlukan, (f) Mengidentifikasi kecenderungan dan mencegah kembali terjadinya masalah, dan (g) Membawa peningkatan praktek sanitasi dan kondisi yang baik di unit usaha. Thaheer, (2005), menyatakan Standard Sanitation Operating Procedures (SSOP) merupakan suatu prosedur standar yang dapat mencakup seluruh area produksi. Pengamatan terhadap pelaksanaan standar prosedur operasi sanitasi secara ringkas di perusahaan CV. Ruyaprima Utama dapat dilihat pada Tabel 11.sedang hal-hal yang perlu dimonitor, tindakan koreksi dan rekaman SSOP dapat dilihat pada Tabel 12.

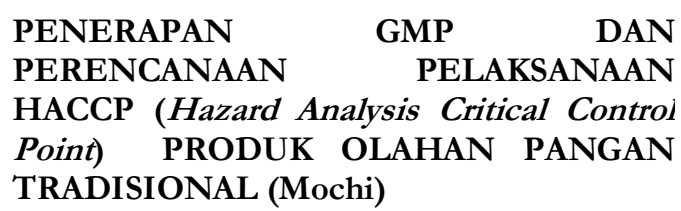

WILDAN WIBAWA PERDANA 
Tabel 12. Pemantauan pada program Sanitation Standard Operating Procedure (SSOP) di perusahaan

\begin{tabular}{|c|c|c|c|c|c|c|c|c|}
\hline \multirow{2}{*}{ No. } & \multirow{2}{*}{$\begin{array}{l}\text { Kunci Persyaratan } \\
\text { Sanitasi }\end{array}$} & \multicolumn{5}{|c|}{ Hal-hal Yang Perlu Dimonitor pada Program SSOP } & \multirow{2}{*}{ Tndaken kordsi } & \multirow{2}{*}{ Rekaman } \\
\hline & & Apa & Dimana & Bagaimana & Kapan & Siapa & & \\
\hline 1 & Keamanan air & \begin{tabular}{|l|l} 
- Kualitas air \\
\end{tabular} & - Distributor Air & $\begin{array}{l}\text { - Cek kualitas air } \\
\text { secara visual }\end{array}$ & -Sebelum operasi & \begin{tabular}{l|}
$\begin{array}{l}\text { - Bagian } \\
\text { penanggungjawab } \\
\text { produksi dan } \\
\text { pemilik perushahan }\end{array}$ \\
\end{tabular} & $\begin{array}{l}\text { - Bila belum memenuhi } \\
\text { standar, dilakukan proses } \\
\text { pengembalian pada } \\
\text { distributor }\end{array}$ & $\begin{array}{l}- \text { Monitoring } \\
\text { kualitas air secara } \\
\text { visual }\end{array}$ \\
\hline 2 & $\begin{array}{l}\text { Kondisi dan kebersihan } \\
\text { permukaan yang kontak } \\
\text { dengan bahan pangan }\end{array}$ & \begin{tabular}{|l|}
-Permukaan harus \\
bersin \\
-Permukaan \\
disanitasi \\
-Sarung tangan dan \\
pakaian harus bersin
\end{tabular} & $\begin{array}{l}\text {-Lime produksi } \\
\text {-Karyawan }\end{array}$ & $\begin{array}{l}\text { - Inspeksi secara } \\
\text { visual } \\
\text { - Inspeksiterhadap } \\
\text { karyawan }\end{array}$ & $\begin{array}{l}\text { - Setiap sebelum } \\
\text { operasi dan setiap } \\
2 \text { jam sekali } \\
\text { - Steip sebelum } \\
\text { operasi dan setiap } \\
2 \text { jam }\end{array}$ & \begin{tabular}{|l|}
-Bagian \\
penanggung jawab \\
produksi \\
- Bagian \\
penanggung jawab \\
produksi
\end{tabular} & $\begin{array}{l}\text {-Stop operasi, dibersihkan } \\
\text { dan disanitasi } \\
\text {-Istirahatkan karyawan }\end{array}$ & $\begin{array}{l}\text { - Monitoring } \\
\text { permukaan yang } \\
\text { kontak dengan } \\
\text { pangan } \\
\text { - Monitoring } \\
\text { terhadap } \\
\text { karyawan }\end{array}$ \\
\hline 3 & Pencegahan kontaminasi silang & $\begin{array}{l}\text {-Kebiasaan } \\
\text { karyawan } \\
\text { - Desain ruang } \\
\text { untuk bahan baku } \\
\text { dan produkjadi }\end{array}$ & \begin{tabular}{|l} 
- Limeproduksi \\
- Karyawan \\
- Toilet daan \\
wastafel \\
- Gudang \\
penyimpanan
\end{tabular} & $\begin{array}{l}\text { - Celkbahan } \\
\text { konsentrasi } \\
\text { sanitaiser } \\
\text { - Cek fasilitas } \\
\text { pencuci tangan } \\
\text { dan toilet } \\
\text { - Inspeksi } \\
\text { dilapangan } \\
\text { - Inspedsi karyawan } \\
\end{array}$ & $\begin{array}{l}\text { - Seiap sebelum } \\
\text { operasi dan setiap } \\
2 \text { jam sekali } \\
\text { - Setiap sebelum } \\
\text { operasi dan setiap } \\
2 \text { jam }\end{array}$ & $\begin{array}{l}\text {-Bagian } \\
\text { penanggung jawab } \\
\text { produksi } \\
\text {-Bagian } \\
\text { penanggung jawab } \\
\text { produksi }\end{array}$ & $\begin{array}{l}\text {-Strpprodidik dan tahan } \\
\text { produkyang } \\
\text { dihasilkan } \\
\text { - Peingatkan dan lath } \\
\text { kembali karyawan } \\
\text { - Evvluasikeamanan } \\
\text { produk, untuk didisposisi, } \\
\text { direproses atau } \\
\text { dimusnahkan } \\
\end{array}$ & $\begin{array}{c}\text { - Monitoring } \\
\text { karyawan } \\
\text { - Monitoring } \\
\text { pembershnn } \\
\text { - Monitoring tata } \\
\text { letak produk } \\
\text { dalam ruangan } \\
\end{array}$ \\
\hline 4 & $\begin{array}{l}\text { Menjaga fasilitas pencuci tangan, } \\
\text { sanitasidan toilet }\end{array}$ & $\begin{array}{l}\text { - Fasilitas aci } \\
\text { tangan } \\
\text { - Fasilitas toilet } \\
\text { - Fasilitas sanitasi }\end{array}$ & $\begin{array}{l}\text { - Tempat cucitangan } \\
\text { - Tempat toilet } \\
\text { - Bagian sanitasi }\end{array}$ & $\begin{array}{l}\text { - Cek fasilitas } \\
\text { pencaci tangan } \\
\text { dan toilet } \\
\text { - Inspeksike } \\
\text { lapangan }\end{array}$ & $\begin{array}{l}\text { - Sebelum operasi, } \\
\text { dan setiap } 4 \text { jam } \\
\text { sekali } \\
\text { - Sebelum operasi } \\
\text { dan setiap } 4 \text { jam } \\
\text { sekali } \\
\end{array}$ & $\begin{array}{l}\text { Bagian } \\
\text { penanggung } \\
\text { jawab produksi }\end{array}$ & 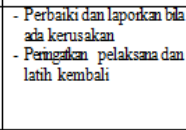 & $\begin{array}{l}\text { a } \\
\text { - Monitoring harian } \\
\text { sanitasi } \\
\text {-Tindakan koreksi } \\
\text { yang dilakukan }\end{array}$ \\
\hline 5 & $\begin{array}{l}\text { Proteksi dari bahan- } \\
\text { bahan kontaminan }\end{array}$ & $\begin{array}{l}\text { - Bahan yang } \\
\text { bepotensi } \\
\text { untuk } \\
\text { mengkontami } \\
\text { nasi }\end{array}$ & $\begin{array}{l}\text {-Produk pangan } \\
\text { - Bahan pengemas } \\
\text {-Permukaan yang } \\
\text { kontaklangsung } \\
\text { dengan pangan }\end{array}$ & $\begin{array}{l}\text { - Cek bahan dan } \\
\text { akses personil } \\
\text { karyawan } \\
\text { - Inspeksi secara } \\
\text { visual }\end{array}$ & $\begin{array}{l}\text { - Sebelum operasi, } \\
\text { dan setiap } 1 \mathrm{jam} \\
\text { sekali } \\
\text { - Sebelum operasi, } \\
\text { dan setiap } 2 \mathrm{jam} \\
\text { sekali } \\
\end{array}$ & $\begin{array}{l}\text { Bagian } \\
\text { penanggung } \\
\text { jawab produksi }\end{array}$ & $\begin{array}{l}\text { - Hilangkan bahan } \\
\text { kontaminan dari } \\
\text { permukaan } \\
\text { - Hindari adanya } \\
\text { genangan air di } \\
\text { dalam ruang produksi }\end{array}$ & $\begin{array}{l}\text { - Monitoring/ } \\
\text { pemantauan } \\
\text { - Tindakan koreksi }\end{array}$ \\
\hline 6 & $\begin{array}{l}\text { Pelabelan, penyimpanan, dan } \\
\text { penggunaan bahan Cleaning } \\
\text { agent }\end{array}$ & $\begin{array}{l}\text { - Pelabelan, } \\
\text { perympanan, dan } \\
\text { Penggumzan bahan }\end{array}$ & \begin{tabular}{|l} 
- Tempatinang \\
perympanan \\
- Tempat paneazan \\
/aplikasi
\end{tabular} & $\begin{array}{l}\text { Cok pelbedan } \\
\text { Cek cara aqliksinya }\end{array}$ & $\begin{array}{l}\text { Satu kali setiap } \\
\text { hari } \\
\text {-Satukali per hari }\end{array}$ & $\begin{array}{l}\text { Bagian } \\
\text { penanggung } \\
\text { jawab produksi }\end{array}$ & $\begin{array}{l}\text { - Pindahkan bahan } \\
\text { toksin tidak beilbed } \\
\text { dengan benar } \\
\text { - Peringatkan karyawan } \\
\text { dan latih kembali } \\
\text { - Stop produksi, dan } \\
\text { rexall prodik yang } \\
\text { terkena } \\
\end{array}$ & $\begin{array}{l}\text { Monitoring/ } \\
\text { penartalan } \\
\text { Tindakan koreksi }\end{array}$ \\
\hline 7 & $\begin{array}{ll}\begin{array}{l}\text { Pengawasan } \\
\text { kesehatan personil }\end{array} & \text { kondisi } \\
\end{array}$ & $\begin{array}{l}\text { - Kayavan dengan } \\
\text { tanda tanda } \\
\text { penyakit luka }\end{array}$ & \begin{tabular}{|l|} 
- Kayawan yang \\
masuk nuang kerja \\
- Pada saat sedang \\
bekerja
\end{tabular} & $\begin{array}{l}\text { - Lakukan inpadsi } \\
\text { terhadap } \\
\text { karyawan } \\
\text { pelaksana }\end{array}$ & $\begin{array}{l}\text { - Sebehm operai } \\
\text { dan setiap } 2 \text { jam } \\
\text { sekali }\end{array}$ & $\begin{array}{l}\text { - Bagian } \\
\text { penanggung } \\
\text { jawab produksi }\end{array}$ & $\begin{array}{l}\text { - Stop prodik dan } \\
\text { than produk yang } \\
\text { dihasilkan }\end{array}$ & $\begin{array}{l}\text { Monitoring kesehatan } \\
\text { kayawan } \\
\text { Tindakan koreksi }\end{array}$ \\
\hline 8 & $\begin{array}{l}\text { Menghilangkan pest dari unit } \\
\text { pengolahan }\end{array}$ & $\begin{array}{l}\text { - Pest dinang } \\
\text { produlsi dan } \\
\text { gudang } \\
\text { penyimpanan }\end{array}$ & \begin{tabular}{|l} 
- Selunh ruangan \\
produksi dan \\
linglangan pabnk
\end{tabular} & $\begin{array}{l}\text { - Cak dan inpedsi } \\
\text { kelapang }\end{array}$ & $\begin{array}{l}\text { - Duakali (2x) setiap } \\
\text { hari }\end{array}$ & $\begin{array}{l}- \text { Bagian } \\
\text { penanggung } \\
\text { jawab produksi }\end{array}$ & $\begin{array}{l}\text { - Tetapkan program } \\
\text { pest control } \\
\text { dengan baik } \\
\text { - Tetapkan tempat' } \\
\text { denh } \\
\text { penemptamya }\end{array}$ & $\begin{array}{l}\text { - Monituing } \\
\text { pest control } \\
\text { - Tindakan koreksi yang } \\
\text { dilekukan }\end{array}$ \\
\hline
\end{tabular}

Penyusunan Rencana HACCP (HACCP Plan) Untuk Produksi Mochi Pada CV. Ruyaprima Utama

Penyusunan rencana HACCP (HACCP Plan) untuk produksi mochi pada CV. Ruyaprima Utama mengacu kepada Codex guidelines dan tujuh prinsip HACCP yang telah diadopsi dan dituangkan dalam acuan (standar) SNI.01.4852-1998 tentang Sistem Analisa Bahaya dan Pengendalian Titik Kritis (BSN, 1998) serta Pedoman penerapannya yaitu Pedoman BSN 1004 : 2002 (BSN, 2002). Rencana HACCP pada perusahaan ini diintegrasikan ke dalam prosedur dan instruksi kerja yang akan memudahkan karyawan (personil yang terlibat) dalam melaksanakannya. Penyusunan dan pengembangan rencana
HACCP dilakukan dengan tahapan sebagai berikut :

1. Memberikan penjelasan dan pengenalan tentang sistem HACCP

Penjelasan dan pengenalan sistem HACCP ini diperuntukan bagi seluruh karyawan dan pihak manajemen yang akanterlibat dalam mengelola sistem manajemen keamanan pangan berdasarkan sistem HACCP di perusahaan yang bersangkutan. Pengenalan tentang sistem

Kualitas sumber daya manusia (SDM) yang terlibat dalam pengolahan pangan untuk memproduksi mochi, sangat berperan dalam membantu kesuksesan perusahaan industri pangan tersebut guna menghasilkan produk mochi yang aman dikonsumsi memerlukan pengetahuan, ketrampilan, keahlian dan tanggung jawab

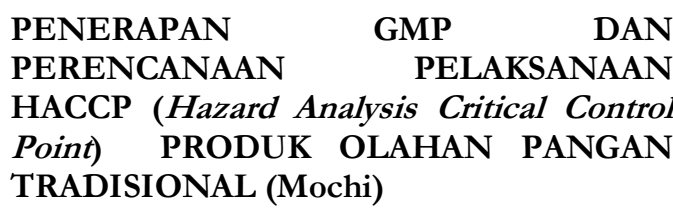

WILDAN WIBAWA PERDANA 
(komitmen) yang tinggi SDM yang mengerjakan dan mengelolanya. Tingkat pengetahuan, ketrampilan, keahlian dan tanggung jawab yang tinggi mutlak diperlukan, karena industri pengolahan pangan untuk menghasilkan produk mochi ini adalah industri yang perlu penanganan secara hati-hati (Bintoro, 2009).

2. Menetapkan Kebijakan Mutu dan Keamanan Pangan Yang Berhubungan Dengan HACCP Plan

Pimpinan tertinggi yang bertanggung jawab terhadap perencanaan, pelaksanaan dan pengawasan prosedur HACCP di CV. Ruyaprima Utama dijabat oleh Pemiliki Perusahaan itu sendiri. Komitmen manajemen puncak ini juga menjadi salah satu unsur dalam pedoman penerapan sistem HACCP (Thaheer, 2005).
3. Pembentukan Tim HACCP (Langkah $\mathrm{Ke}-1)$

Pembentukan Tim HACCP disusun berdasarkan struktur organisasi yang sudah ada dalam badan usaha CV. Ruyaprima Utama sehingga legalitas dari tim ini dapat dipertanggungjawabkan. Pimpinan puncak/tertinggi secara formal organisasi adalah orang yang memiliki wewenang tertinggi dalam pengendalian perusahaan. Berkaiatan dengan pelaksanaan kebijakan penerapan sistem manajemen HACCP, pimpinan puncak memberikan mandatnya kepada wakil manajemen (Ketua/Koordinator Tim HACCP) untuk melaksanakan aktivitas persiapan sertifikasi dan pemantauan dalam penerapannya (Stevenson, 1990).

Tabel 13.Uraian Tugas Tim HACCP di CV. Ruyaprima Utama

\begin{tabular}{|c|c|c|}
\hline No. & Jabatan & Uraian Tugas Tim HACCP \\
\hline 1. & $\begin{array}{l}\text { Ketua Tim } \\
\text { HACCP }\end{array}$ & $\begin{array}{l}\text { - Menyiapkan, membuat dan mengesahkan dokumen manual HACCP } \\
\text { - Menjamin dan bertanggung jawab penuh atas penerapan sistem HACCP di dalam organisasi } \\
\text { secara meneyeluruh } \\
\text { - Memberikan program pelatihan kepada semua karyawan } \\
\text { - Melakukan verifikasi/audit secara berkala terhadap sistem HACCP dan tindakan perbaikan } \\
\text { serta perubahan yang diperlukan } \\
\text { - Mengadakan dan memimpin rapat tim HACCP secara berkala } \\
\text { - Melakukan dan menjaga hubungan dengan pihak konsultan HACCP }\end{array}$ \\
\hline 2. & $\begin{array}{l}\text { Wakil } \\
\text { Ketua }\end{array}$ & $\begin{array}{l}\text { - Membantu Ketua tim HACCP dalam menjalankan tugas penerapan sistem HACCP } \\
\text { - Menjalankan tugas dan fungsi ketua, jika yang bersangkutan berhalangan } \\
\text { - Membantu Ketua tim dalam program pelatihan sistem HACCP terhadap karyawan } \\
\text { perusahaan } \\
\text { - Memberikan program pelatihan kepada karyawanh harian terhadap penerapan sistem } \\
\text { HACCP } \\
\text { - Memberikan masukan, usulan perbaikan sistem HACCP kepada Ketua tim sehingga terjadi } \\
\text { peningkatan mutu atas sistem HACCP } \\
\text { - Membantu Ketua tim HACCP dalam program pelatihan, penerapan dan perbaikan sistem } \\
\text { HACCP di dalam perusahaan }\end{array}$ \\
\hline 3. & Sekretaris & $\begin{array}{l}\text { - Menyiapkan dan membuat dokumen manual HACCP } \\
\text { - Mengendalikan, mendistribusikan dokumen HACCP dan menjamin bahwa setiap unit } \\
\text { menerima dokumen HACCP yang benar dan terbaru } \\
\text { - Menyimpan semua rekaman dokumen, catatan dan data terhadap semua dokmen HACCP } \\
\text { dengan baik dan rapi } \\
\text { - Melakukan revisi terhadap dokumen sesuai dengan perubahan yang telah ditetapkan } \\
\text { dan mendistribusikan dokumen yang baru serta menarik dokumen yang lama } \\
\text { - Memusnahkan dokumen yang sudah tidak terpakai atau yang sudah melewati masa simpan } \\
\text { dokumen }\end{array}$ \\
\hline 4. & Anggota & $\begin{array}{l}\text { - Membantu persiapan dan pembuatan dokumen manual sistem HACCP } \\
\text { - Memberikan masukan, usulan perbaikan sistem HACCP sehingga terjadi peningkatan mutu } \\
\text { atas sistem HACCP } \\
\text { - Menjadi fungsi kontrol dalam pelaksanaan sistem HACCP di dalam lingkungan unit masing- } \\
\text { masing }\end{array}$ \\
\hline
\end{tabular}

Prosedur untuk rencana HACCP atau HACCPPlan meliputi seluruh proses
PENERAPAN
PERENCANAAN
GMP
HACCP (Hazard Analysis Critical Control
Point) PRODUK OLAHAN PANGAN
TRADISIONAL (Mochi)

produksi, mulai dari penerimaan bahan baku sampai dengan penyimpanan

WILDAN WIBAWA PERDANA 
sementara produk akhir di gudang penyimpanan dan pendistribusiannya. Bahaya biologi (mikrobiologi) untuk produk mochi yang mungkin timbul adalah E. Coli, coliform, dan kapang, tetapi karena dalam proses produksinya air yang digunakan merupakan air dalam kemasan dan proses pendistribusiannya secara langsung dan cepat tidak memungkinkan bahaya biologi tersebut untuk tumbuh. (BSN, 1998).
Bahaya kimia dapat berasal dari bahan pembersih (deterjen), Sanitizer dan cemaran logam-logam berat yang berasal dari bahan baku tepung ketan dan tepung tapioka; sedangkan bahaya fisik bukan merupakan suatu bahaya yang potensial.

4. Deskripsi Produk Dan Identifikasi Pengguna (Langkah Ke-2 dan Langkah $\mathrm{Ke}-3$ )

Deskripsi produk mochi hasil produski CV. Ruyaprima Utama dan identifikasi penggunaannya dapat dilihat pada Tabel 14

Tabel 14. Deskripsi Produk Mochi produksi CV. Ruyaprima Utama

\begin{tabular}{|c|c|c|}
\hline No. & Keterangan & Uraian \\
\hline 1. & Nama Produk & Mochi \\
\hline 2. & Deskripsi Umum & $\begin{array}{l}\text { Produk kue yang terbuat dari beras ketan yang dikukus lalu ditumbuk dengan sejenis alu } \\
\text { hingga lembut mulut, setelah itu dibentuk bulat dengan beragam isian }\end{array}$ \\
\hline 3. & $\begin{array}{l}\text { Komposisi bahan } \\
\text { baku dan bahan } \\
\text { tambahan lain }\end{array}$ & $\begin{array}{l}\text { Tepung ketan, tepung tapioka, gula pasir, kacang tanah, pewarna dan perisa makanan, } \\
\text { dan air }\end{array}$ \\
\hline 4. & $\begin{array}{l}\text { Karakteristik } \\
\text { produk }\end{array}$ & $\begin{array}{l}\text {-Fisik : kenyal, semi kering berbentuk khas bulat khas mochi dengan ukuran bobot netto } \\
200 \text { gram, rasa dan aroma normal } \\
\text {-Kimia : kadar air } 47,3504 \% \text {, kadar protein } 5,6020 \% \text {, Tidak mengandung boraks, dan } \\
\text { kadar lemak 1,1452\% } \\
\text {-Mikrobiologi : E. Coli negatif; dan kapang negatif }\end{array}$ \\
\hline 5. & $\begin{array}{l}\text { Metode } \\
\text { Pengemasan }\end{array}$ & Dilakukan secara manual, pengemasan menggunakan kemasan karton beralas plastik. \\
\hline 6. & Pelabelan & $\begin{array}{l}\text { Nama dan kode produk, bobot netto, komposisi, nama dan alamat perusahaan, tanggal } \\
\text { kadaluwarsa, tanggal produksi, kondisi penyimpanan dan petunjuk penggunaannya }\end{array}$ \\
\hline 7. & Umur simpan & 6 hari selama disimpan dalam suhu chiller $\left(10^{\circ} \mathrm{C}\right)$ dan 3 hari disuhu ruang \\
\hline 8. & $\begin{array}{l}\text { Kondisi } \\
\text { penyimpanan }\end{array}$ & Suhu ruang, tidak terkena cahaya matahari langsung, tempat tidak berbau. \\
\hline 9. & Distribusi & $\begin{array}{l}\text { Pendistribusian secara langsung (konsumen dan distributor datang langsung ketempat } \\
\text { penjualan/counter) }\end{array}$ \\
\hline 10. & Penjualan & Dari industri langsung ke distributor dan konsumen \\
\hline 11. & Target konsumen & $\begin{array}{l}\text { Produk dapat dikonsumsi oleh semua orang dan tidak ditujukan secara khusus untuk } \\
\text { kelompok populasi tertentu }\end{array}$ \\
\hline 12. & Cara penggunaan & Produk dapat langsung dikonsumsi \\
\hline
\end{tabular}

5. Penentuan dan Verifikasi Diagram Alir Proses Produksi (Langkah Ke-4 dan Langkah Ke-5)

Diagram alir proses produksi dibuat dengan tujuan untuk mempermudah analisis HACCP. Diagram alir proses ini diharapkan dapat membantu mengidentifikasi sumber kontaminasi yang potensial dan upaya-upaya apa yang dapat dilakukan untuk mengendalikan bahaya tersebut. Penentuan diagram alir proses pembuatan produk mochi di perusahaan dilakukan dengan mencatat seluruh tahapan proses, sejak bahan baku diterima hingga produk siap disimpan sementara dan didistribusikan ke konsumen. Diagram alir proses produksi pembuatan mochi hasil verifikasi di lapang dapat dilihat pada Gambar 9.

\author{
PENERAPAN \\ PERENCANAAN

WILDAN WIBAWA PERDANA 


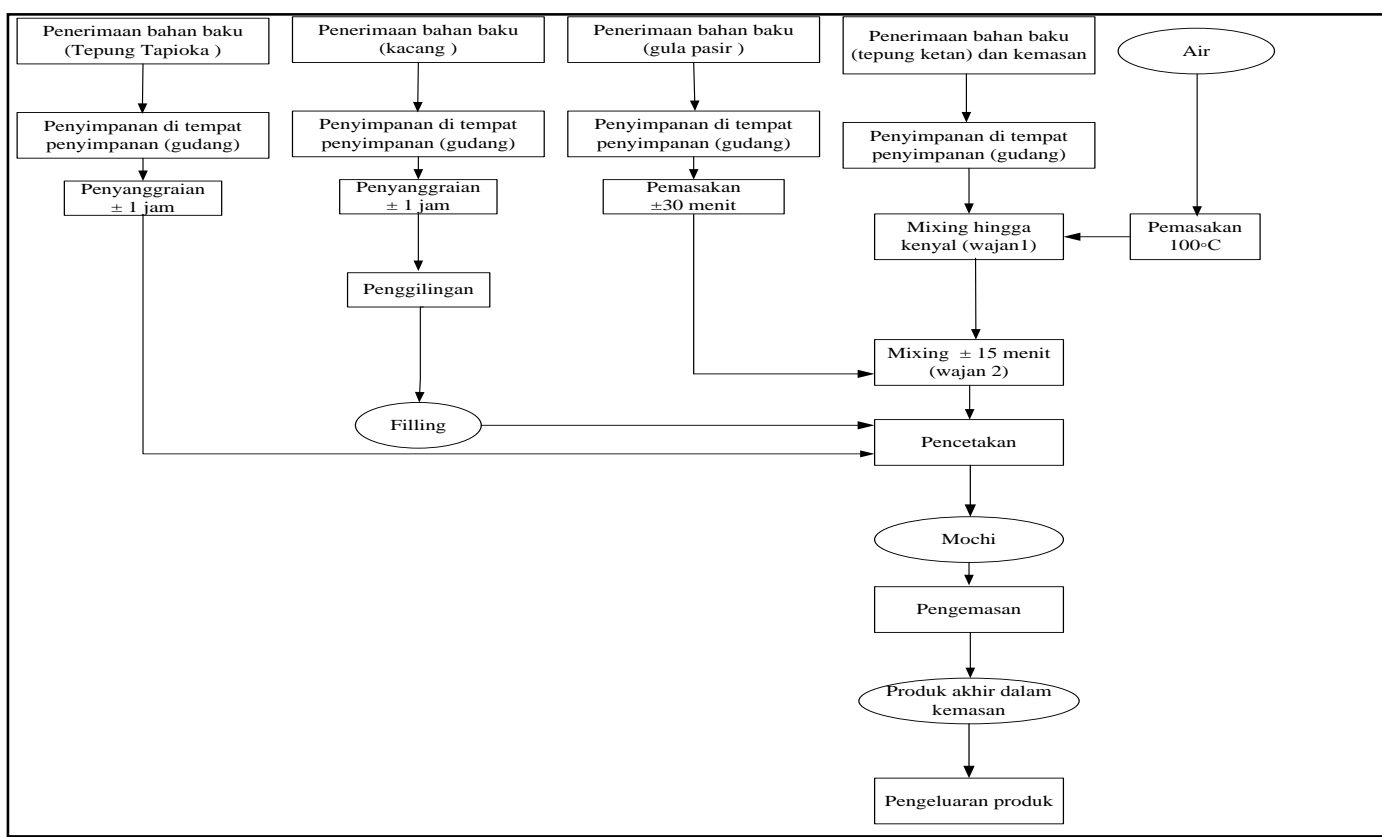

Gambar 8. Diagram Alir Proses Produksi Mochi di CV. Ruyaprima Utama Hasil Verifikasi.

\begin{abstract}
Stevenson (1999), Menyatakan Sistem HACCP dikatakan bersifat komprehensif, karena sistem HACCP ini berkaitan erat dengan ramuan/ingredien pangan, proses pengolahan dan tujuan penggunaan produk pangan selanjutnya. Proses produksi atau pembuatan mochi yang dilakukan di CV. Ruyaprima Utama meliputi tahapan :
\end{abstract}

a. Penerimaan bahan baku, bahan pembantu/penolong, bahan tambahan pangan (BTP) dan bahan pengemas merupakan tahap paling awal dalam proses produksi pembuatan mochi di CV. Ruyaprima Utama. Pemeriksaan dilakukan setiap kali kedatangan bahan di perusahaan CV. Ruyaprima Utama sesuai dengan spesifikasi yang ditetapkan perusahaan secara visual, dilakukan langsung pemilik perusahaan dan penanggung jawab produksi sesuai dengan SOP (standar prosedur operasi) perusahaan.

b. Penyimpanan bahan di perusahaan dengan cara disimpan terpisah satu sama lain di dalam ruang/gudang yang bersih, cukup penerangan, terjamin aliran udaranya, dan pada suhu.

c. Penimbangan dilakukan pada bahan yang digunakan untuk proses

\footnotetext{
PENERAPAN PERENCANAAN$$
\text { GMP }
$$$$
\text { PELAKSANAAN }
$$$$
\text { HACCP (Hazard Analysis Critical Control }
$$$$
\text { Point) PRODUK OLAHAN PANGAN }
$$$$
\text { TRADISIONAL (Mochi) }
$$

pembuatan mochi yaitu tepung ketan, tepung tapioka, kacang tanah, dan gula pasir.

d. Proses penyangraian ini dibagi menjadi dua, yaitu penyangraian tepung tapioka dan penyangraian kacang tanah. Penyangraian tepung tapioka ini bertujuan untuk mengurangi kadar air yang terdapat pada tepung tapioka. Sedangkan penyangraian kacang tanah bertujuan untuk memasakkan kacang tanah sehingga akan mudah untuk diproses selanjutnya.

e. Proses penggilingan kacang tanah ini bertujuan untuk menghancurkan kacang tanah sehingga akan mudah untuk dibuat sebagai filling (isian).

f. Proses pemasakan gula bertujuan untuk mencairkan gula sehingga dapat mudah dilakukan pencampuran pada proses selanjutnya. Pemasakan gula dilakukan selama dilakukan selama \pm 30 menit dengan suhu $100^{\circ} \mathrm{C}$.

g. Proses pencampuran (mixing) dilakukan dengan dua tahap, yaitu pencampuran pertama antara tepung ketan dengan air panas $\left(100^{\circ} \mathrm{C}\right)$ sampai adonan kenyal, dan pencampuran kedua yaitu pencampuran antara tepung ketan

WILDAN WIBAWA PERDANA 
dengan gula pasir yang telah dicairkan yang adonan yang kalis.

h. Proses pencetakan bertujuan untuk membentuk mochi menjadi bentuk adonan kecil agar mempermudah untuk dikonsumsi. Proses pencetakan dilakukan pengiisian (filling).

i. Proses pengemasan dilakukan secara manual oleh karyawan. Kemasan yang digunakan adalah karton beralaskan plastik jenis PE (Poly Etilen). Produk disimpan pada rak penyimpanan sementara.

6. Analisis Bahaya dan Penentuan Tindakan Pencegahannya (Langkah Ke-6, Prinsip 1 HACCP)

Analisis bahaya merupakan prinsip ke-1 dari 7 (tujuh) prinsip penerapan sistem HACCP. Analisis bahaya adalah proses pengumpulan dan menilai informasi bahaya dan keadaan sampai terjadinya bahaya untuk menentukan mana yang berdampak nyata terhadap keamanan pangan dan harus ditangani dalam rencana HACCP sesuai dengan SNI 01.4852-1998 (BSN, 1999). Besarnya peluang potensi bahaya untuk bahan baku utama dan bahan pembantu serta bahan tambahan pangan ditetapkan berdasarkan hasil analisis dari laboratorium yang sudah terakreditasi, sedang untuk tahapan proses produksi ditetapkan berdasarkan hasil observasi dan pengamatan catatan yang ada di lapangan. Analisis bahaya dan tindakan pencegahannya dalam penelitian ini dibahas secara khusus dan komprehensif serta difokuskan pada proses produksi mochi yang dibuat di CV. Ruyaprima Utama.

Tabel 15. Analisis Bahaya dan Tindakan Pencegahannya pada Proses Produksi Mochi Momi di CV. Ruyaprima Utama

\begin{tabular}{|c|c|c|c|c|c|c|}
\hline $\begin{array}{c}\text { Langkah } \\
\text { Proses/Tahap }\end{array}$ & $\begin{array}{l}\text { Potensi Bahaya yang } \\
\text { mungkin timbul } \\
\text { berkembang } \\
\text { (biologis, kimia, fisik) }\end{array}$ & Penyebab/Justifikasi bahaya & \begin{tabular}{|c|} 
Peluang \\
trjadinya bahaya \\
$(\mathrm{H}, \mathrm{M}, \mathrm{L})$
\end{tabular} & $\begin{array}{l}\text { Severity (Tingkat } \\
\text { keakutan bahaya) } \\
(\mathrm{h}, \mathrm{m}, \mathrm{D})\end{array}$ & $\begin{array}{c}\text { Signifikansi } \\
\text { bahaya } \\
\text { (YN) }\end{array}$ & $\begin{array}{l}\text { Tindakan Pencegahan } \\
\text { Bahaya yang telah } \\
\text { diidentifikasi }\end{array}$ \\
\hline \multirow{3}{*}{$\begin{array}{l}\text { Penyangrain } \\
\text { Tepung } \\
\text { tapioka }\end{array}$} & B : Tidak ada & - & - & - & - & - \\
\hline & $\begin{array}{l}\mathrm{K}: \text { Tidak ada cemaran } \\
\text { bahan kimia }\end{array}$ & - & - & - & - & - \\
\hline & $\begin{array}{c}F: \begin{array}{c}\text { Benang, tali plastik, } \\
\text { potongan serangga }\end{array} \\
\text {, }\end{array}$ & $\begin{array}{l}\text { Bahan baku tepung tapioka yang } \\
\text { digunakan kadang - kadang } \\
\text { mengandung cemaran fisik berupa } \\
\text { benang, potongan tali plastik dan } \\
\text { potongan serangga } \\
\text { Hasil pemantauan dan pemeriks aan } \\
\text { catatan rekaman di perusahaan } \\
\text { ditemukan adanya benang, potongan tali } \\
\text { plastik dan potongan serangga yang } \\
\text { jumlahnya kecil }\end{array}$ & $\mathrm{L}$ & 1 & $\mathrm{~N}$ & $\begin{array}{l}\text { Lakukan pengayakan } \\
\text { Cemaran fisisk yang diperoleh } \\
\text { dipisahkan dan dibuang ke } \\
\text { trmpat sampha }\end{array}$ \\
\hline \multirow{3}{*}{$\begin{array}{l}\text { Penyangrain dan } \\
\text { penghancuran } \\
\text { kacang Tanah }\end{array}$} & B : Tidak ada & - & - & - & - & - \\
\hline & K : Tidak ada & - & - & - & - & - \\
\hline & $F:$ batu & $\begin{array}{l}\text { Bahan baku kacang digunakan kadang - } \\
\text { kadang mengandungcemaran fisik } \\
\text { berupababut } \\
\text { Hasil pemantauan dan pemeriksaan } \\
\text { catatan rekaman di perus ahaan } \\
\text { ditemukan adanya batu yang jumlahnya } \\
\text { kecil }\end{array}$ & $\mathrm{L}$ & 1 & $\mathrm{~N}$ & $\begin{array}{l}\text { Lakukan pemisahan secara } \\
\text { manual (oleh pekerja) } \\
\text { Cemaran fisik yang diperoleh } \\
\text { dipisahkan dan dibung ke } \\
\text { trmpat sampah }\end{array}$ \\
\hline
\end{tabular}

\section{PENERAPAN PERENCANAAN GMP

WILDAN WIBAWA PERDANA 
Tabel 15. Analisis Bahaya dan Tindakan Pencegahannya pada Proses Produksi Mochi Momi di CV. Ruyaprima Utama (lanjutan)

\begin{tabular}{|c|c|c|c|c|c|c|}
\hline $\begin{array}{l}\text { Langkah } \\
\text { Proses/Tahap }\end{array}$ & $\begin{array}{l}\text { Potensi Bahaya yang } \\
\text { mung kin timbul/ } \\
\text { berkembang (biologis, } \\
\text { kimia, fisik) }\end{array}$ & Penyebab/Justifikasi bahaya & $\begin{array}{l}\text { Peluang } \\
\text { trjadinya } \\
\text { bahaya } \\
(\mathrm{H}, \mathrm{M}, \mathrm{L})\end{array}$ & $\begin{array}{l}\text { Severity (Tingkat } \\
\text { keakutan bahaya) } \\
(\mathbf{h}, \mathrm{m}, \mathrm{l})\end{array}$ & $\begin{array}{l}\text { Signifikansi } \\
\text { bahaya } \\
\text { (Y/N) }\end{array}$ & $\begin{array}{c}\text { Tindakan Pencegahan Bahaya } \\
\text { yang telah diidentifikasi }\end{array}$ \\
\hline \multirow{3}{*}{$\begin{array}{l}\text { Penerimaan } \begin{array}{l}\text { bahar } \\
\text { baku kacang tanah }\end{array} \\
\text { Pacang }\end{array}$} & Tidalk ada & - & - & - & - & - \\
\hline & K:Tidak ada & - & - & - & - & - \\
\hline & $F:$ Kotoran & $\begin{array}{l}\text { - Pihak supplier kurang memperhatikan } \\
\text { lingkungan }\end{array}$ & $\mathrm{I}$ & 1 & $\mathrm{~N}$ & $\begin{array}{l}\text { - Inspelksi dan pemeriksaan oleh } \\
\text { bagian penanggumg jawsb produksi }\end{array}$ \\
\hline \multirow{3}{*}{$\begin{array}{l}\text { Penerimaan bahan } \\
\text { pembantu air } \\
\text { untuk } \\
\text { produksi }\end{array}$} & B:Tidak ada & - & - & - & - & \begin{tabular}{|l|}
$\begin{array}{l}\text { Adanya jaminan dari pemas ok } \\
\text { (distributor Aqua) }\end{array}$ \\
\end{tabular} \\
\hline & F: Tidak ada & - & - & - & - & - \\
\hline & F:Tidak ada & - & - & - & - & - \\
\hline \multirow{2}{*}{$\begin{array}{l}\text { Penerimaan bahan } \\
\text { pengemas kotak } \\
\text { karton }\end{array}$} & $\begin{array}{l}\text { B: Tidak ada } \\
\text { K:Tidak ada }\end{array}$ & - & - & - & - & - \\
\hline & $\begin{array}{l}\text { F: Debu, kotoran yang } \\
\text { menempel } \\
\text { karton }\end{array}$ & 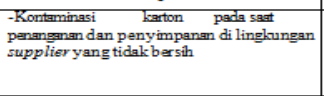 & L & 1 & $\bar{N}$ & 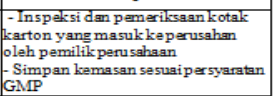 \\
\hline \multirow[t]{3}{*}{$\begin{array}{l}\mid \begin{array}{ll}\text { Penyimpanan } & \\
\text { bahan bahan } & \text { di } \\
\text { gudang (sementara) }\end{array} \\
\end{array}$} & B : $: \begin{array}{c}\text { Kecoa, lalat dan } \\
\text { serangga }\end{array}$ & $\begin{array}{l}\text { - Binatang atau hewan tersebut dapat } \\
\text { menyebabkankonktaminasi silang bakteri } \\
\text { pada bahan-bahan yang disimpan di } \\
\text { gudang }\end{array}$ & $\mathrm{L}$ & $\mathrm{m}$ & $\mathrm{N}$ & $\begin{array}{l}\text { - Lakukan pengendalian hama (pert } \\
\text { control) dengan tepat }\end{array}$ \\
\hline & K $\begin{array}{c}\text { : Residu bahan } \\
\text { sanitaiser }\end{array}$ & $\begin{array}{l}\text { - Siss residu bahan sanitaicer yang terdapa paids } \\
\text { alat yang dipakai dapat mengkontaminas } \\
\text { bahan dicampur }\end{array}$ & $\mathrm{I}$ & $\mathrm{m}$ & N & $\begin{array}{l}\text { - Gunakan sanitaiser yang diizinkan } \\
\text { pemerintah - Gunakand osis yang } \\
\text { tepat }\end{array}$ \\
\hline & F: Debu, kotoran & - Ruang gudang penyimp anan tidak bersih & $\mathrm{L}$ & $\mathrm{m}$ & $\mathbb{N}$ & 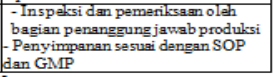 \\
\hline
\end{tabular}

Tabel 15. Analisis Bahaya dan Tindakan Pencegahannya pada Proses Produksi Mochi Momi di CV. Ruyaprima Utama (lanjutan)

\begin{tabular}{|c|c|c|c|c|c|c|}
\hline$\underset{\substack{\text { Langkah } \\
\text { ProsesTahap }}}{ }$ & $\begin{array}{c}\text { Potensi Bahaya yang } \\
\text { mungkin } \\
\text { timbul/ } \\
\text { berkembang }\end{array}$ & Penyebab/Justifikasi bahaya & $\begin{array}{l}\text { Peluang } \\
\text { trjadinya } \\
\text { bahaya } \\
(\mathrm{H}, \mathrm{M}, \mathrm{L})\end{array}$ & $\begin{array}{c}\text { Severing (Tingkat } \\
\text { keakutan bahaya) } \\
\text { m, l) }\end{array}$ & $\underset{\substack{\text { Signifikansi } \\
\text { bahaya } \\
(\mathbf{Y} / \mathrm{N})}}{ }$ & $\begin{array}{l}\text { Tindakan Pencegahan Bahaya } \\
\text { yang telah diidentifikasi }\end{array}$ \\
\hline \multirow[t]{3}{*}{\begin{tabular}{|l|} 
Penimbangan \\
bahan baku \\
dan bahan \\
lainnya untuk \\
persiapan \\
formulasi \\
\end{tabular}} & 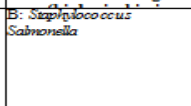 & $\begin{array}{l}\text { Adanya kontaminasi balteri dari alat dan } \\
\text { personil yalg menangani penimbangan } \\
\text { bahan bahu dan bahann lainnya }\end{array}$ & $\mathrm{M}$ & $\mathrm{m}$ & $\mathrm{N}$ & $\begin{array}{l}\text { Penerapan SSOP dan GMP dengan } \\
\text { benar } \\
\text { SSOP (Kas ehatan dan Higiene } \\
\text { pelkerja) } \\
\text { Pada tahap selanjutryya ada proses } \\
\text { pemaskan. }\end{array}$ \\
\hline & K : Tidak ada & & - & - & - & - \\
\hline & F: Debu, kotoran & $\begin{array}{l}\text { Kontaminasi pada alat yang } \\
\text { digunakan dalam alat penimbang }\end{array}$ & I & 1 & $\mathrm{~N}$ & $\begin{array}{l}\text { - Inspelksi dan pemeriks asa oleh } \\
\text { bagian penangung jawab produksi }\end{array}$ \\
\hline \multirow{3}{*}{$\begin{array}{l}\text { Pencampurandan } \\
\text { pemasakan (wajan 1) }\end{array}$} & B : tidak ada & & - & - & - & - \\
\hline & K : tidak ada & & - & - & - & - \\
\hline & F: Debu, kotoran & $\begin{array}{l}\text { - Kontaminasialatdari linghom gan } \\
\text { produlsi }\end{array}$ & I & $\mathrm{m}$ & $\mathbb{N}$ & $\begin{array}{l}\text { - Inspelsi dan pemariksaan oleh bagian } \\
\text { penangung jamwab producksi } \\
\text { - Lakukan pembers ihan }\end{array}$ \\
\hline \multirow{3}{*}{$\begin{array}{l}\text { Pencampuran dan } \\
\text { pemas sakan (wajan 2) }\end{array}$} & $B$ : tidak ada & 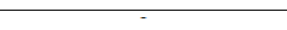 & - & - & - & - \\
\hline & $\mathrm{K}$ : tidak ada & & - & - & - & \\
\hline & F: Debu, kotoran & $\begin{array}{l}\text { Kontamina si alatdari linghomgan } \\
\text { produksi }\end{array}$ & I & $\mathrm{m}$ & $\mathrm{N}$ & $\begin{array}{l}\text { Inspelssi dan pemeriksagn oleh bagiar } \\
\text { penangung jawsab produksi } \\
\text { - Lakulkan pembersihan }\end{array}$ \\
\hline \multirow[t]{3}{*}{ Pencetakan } & 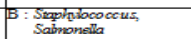 & $\begin{array}{l}\text { Adanya kontaminasi bakteri yang } \\
\text { terbawa dari tangan karyawan }\end{array}$ & $\mathrm{M}$ & $\mathrm{m}$ & $\mathrm{N}$ & $\begin{array}{l}\text { Penerapan SSOP dan GMP dengan } \\
\text { benar }\end{array}$ \\
\hline & $\mathrm{K}:$ Tidak ada & & - & - & - & - \\
\hline & F: Debu, kotoran & $\begin{array}{l}\text { Kontaminasi pada dari tangan dan pakaid } \\
\text { karywawan yang digumalan delam } \\
\text { pencetakan }\end{array}$ & I & 1 & $\mathrm{~N}$ & $\begin{array}{l}\text { Inspeksi dan pemeriks aan oleh } \\
\text { bagian penangemng jawab } \\
\text { Lakukan pembersihan }\end{array}$ \\
\hline
\end{tabular}

Tabel 15. Analisis Bahaya dan Tindakan Pencegahannya pada Proses Produksi Mochi Momi di CV. Ruyaprima Utama (lanjutan)

\begin{tabular}{|c|c|c|c|c|c|c|}
\hline $\begin{array}{c}\text { Langkah } \\
\text { Proses Tahap }\end{array}$ & $\begin{array}{c}\text { Potensi Bahaya yang } \\
\text { mungkin timbul/ } \\
\text { berkembang (biologis, } \\
\text { kimia, fisik) }\end{array}$ & Penyebab/Justifikasi bahaya & $\begin{array}{l}\text { Peluang } \\
\text { trjadinya } \\
\text { bahaya } \\
(\mathrm{H}, \mathrm{M}, \mathrm{L})\end{array}$ & $\begin{array}{c}\text { Severity (Tingkat } \\
\text { keakutan bahaya) (h, } \\
\text { m, l) }\end{array}$ & $\begin{array}{l}\text { Signifikansi } \\
\text { bahaya } \\
\text { (Y/N) }\end{array}$ & $\begin{array}{l}\text { Tindakan Pencegahan Bahaya } \\
\text { yang telah diidentifikasi }\end{array}$ \\
\hline \multirow{3}{*}{\begin{tabular}{|l|} 
Pengemasan \\
dengan kotak \\
karton
\end{tabular}} & B:Tidak ada & $\cdot$ & $\cdot$ & $\cdot$ & $\cdot$ & $\cdot$ \\
\hline & $\mathrm{K}:$ Tidak ada & - & - & - & - & - \\
\hline & F: Debu, kotoran & $\begin{array}{l}\text { Kontaminasidebu dan kotoran } \\
\text { pada karton }\end{array}$ & L & $\mathrm{L}$ & $\mathrm{N}$ & $\begin{array}{l}\text { Pemeriksagn oleh bagian penanggung } \\
\text { jawab produksi } \\
\text { - Lakukan pembersihan (SSOP } \\
\text { Kebersihan dan Sanitasi) }\end{array}$ \\
\hline \multirow{3}{*}{$\begin{array}{l}\text { Penyimpanan } \\
\text { produk sementara }\end{array}$} & B:Tidak ada & - & - & - & - & - \\
\hline & K: Tidak ada & - & - & - & - & - \\
\hline & F: Debu, kotoran & $\begin{array}{l}\text { Ruang gudang panyimpanan } \\
\text { tidak bersih }\end{array}$ & $\mathrm{L}$ & 1 & $N$ & $\begin{array}{l}\text { PenerapanSSOP pencegahan } \\
\text { kontaminasi silang (Pembersihan) } \\
\text { - Inspelksi oleh bagian Penanggung } \\
\text { jawab produksi dan lahulkan } \\
\text { pembersihan }\end{array}$ \\
\hline \multirow{3}{*}{$\begin{array}{l}\text { Penginiman dan } \\
\text { Pendistribusian }\end{array}$} & B:Tidak ada & - & - & - & - & $\cdot$ \\
\hline & K: Tidak ada & - & - & - & - & - \\
\hline & F:Tidak ada & - & - & - & - & - \\
\hline
\end{tabular}

Keterangan :Peluang : H= High, M=Medium, L=Low; Severity : h=high, $\mathrm{m}=$ medium, l=low; dan Signifikansi : $\mathrm{Y}=\mathrm{Yes}$ dan $\mathrm{N}=$ No.
PENERAPAN
PERENCANAAN
GMP
DAN 
Tindakan pencegahan/pengendalian bahaya kimia berupa cemaran logam-logam berat seperti timbal $(\mathrm{Pb})$ dan cemaran arsen (As) pada tepung tapioka dilakukan dengan cara : (1) Penetapan spesifikasi sesuai dengan persyaratan SNI tepung tapioka (SNI 01-2997-1996) dimana ditetapkan bahwa kandungan timbal $(\mathrm{Pb})$ maksimal $1,00 \mathrm{mg} / \mathrm{kg}$ dan cemaran arsen (As) maksimal 0,50 $\mathrm{mg} / \mathrm{kg}$; (2) Permintaan jaminan dari pemasok melalui pemeriksaan certificate of analysis (COA) setiap kali kedatangan tepung tapioka di perusahaan; dan (3) Pengujian keamanan dan mutu tepung tapioka secara eksternal sesuai dengan SNI 01-2997-1996 setiap 6 bulan sekali. Bila bahan baku tepung tapioka yang diterima di perusahaan tersebut tidak sesuai COA dan spesifikasi perusahan, maka bahan tepung tapioka itu ditolak dan dikembalikan kepada pihak pemasok
Dalam melakukan kajian bahaya yang potensial pada penerimaan bahan baku (bahan baku utama, bahan pembantu utama dan bahan tambahan pangan) untuk produksi mochi terhadap keamanan pangan telah dilakukan pengujian beberapa parameter keamanan pangan dan parameter mutu bahan baku untuk produksi mochi yang digunakan oleh perusahaan CV. Ruyaprima Utama. Bahan baku utama tepung ketan, tepung tapioka, dan gula yang diuji, yaitu kandungan cemaran mikroba, logam berat dan arsen, dan cemaran fisik serta dibandingkan dengan standar yang ditetapkan oleh regulasi pemerintah; yakni SNI 01-44471998 (Untuk tepung ketan), SNI 01-29971996 (untuk tepung tapioka), dan SNI No. 01-3140-2001(Untuk gula pasir), dengan hasil sebagaimana dapat dilihat dalam Tabel 16, 17 dan Tabel 18.

Tabel 16. Hasil Pengujian Cemaran Fisik, Kimia dan Mikroba Pada Tepung Ketan

\begin{tabular}{|c|c|c|c|}
\hline Parameter & Satuan & $\begin{array}{c}\text { Hasil } \\
\text { Pengujian }\end{array}$ & $\frac{\text { SNI 01-4447 - }}{1998}$ \\
\hline $\begin{array}{l}\text { Cemaran Fisik } \\
\text { - Benda asing } \\
\text {-Serangga dalam bentuk stadia dan potongan- } \\
\text { potongannya }\end{array}$ & $\begin{array}{l}- \\
-\end{array}$ & $\begin{array}{l}\text { Tidak ada } \\
\text { Tidak ada }\end{array}$ & $\begin{array}{l}\text { Tidak ada } \\
\text { Tidak ada }\end{array}$ \\
\hline Cemaran logam - Timbal (Pb) & $\mathrm{mg} / \mathrm{kg}$ & Tidak ada & Maksimal 1,00 \\
\hline Cemaran arsen (As) & $\mathrm{mg} / \mathrm{kg}$ & Tidak ada & Maksimal 0,50 \\
\hline $\begin{array}{l}\text { Cemaran mikroba } \\
\text { - Angka lempeng total (ALT) } \\
\text { - E. Coli } \\
\text { - Kapang }\end{array}$ & $\begin{array}{l}\text { Koloni/g } \\
\text { Koloni/g } \\
\text { Koloni/g }\end{array}$ & $\begin{array}{l}7,3 \times 10^{2} \\
\text { Tidak ada } \\
10\end{array}$ & $\begin{array}{c}10^{6} \\
10 \\
10^{4}\end{array}$ \\
\hline
\end{tabular}

Tabel 17. Hasil Pengujian Cemaran Fisik, Kimia dan Mikroba Pada Tepung Tapioka

\begin{tabular}{|c|c|c|c|}
\hline Parameter & Satuan & $\begin{array}{c}\text { Hasil } \\
\text { Pengujian }\end{array}$ & $\begin{array}{c}\text { SNI 01-2997- } \\
1996\end{array}$ \\
\hline $\begin{array}{l}\text { Cemaran Fisik } \\
\text { - Benda asing } \\
\text {-Serangga dalam bentuk stadia dan potongan- } \\
\text { potongannya }\end{array}$ & $\begin{array}{l}- \\
-\end{array}$ & $\begin{array}{l}\text { Tidak ada } \\
\text { Tidak ada }\end{array}$ & $\begin{array}{l}\text { Tidak ada } \\
\text { Tidak ada }\end{array}$ \\
\hline Cemaran logam - Timbal (Pb) & $\mathrm{mg} / \mathrm{kg}$ & Tidak ada & Maksimal 1,00 \\
\hline Cemaran arsen (As) & $\mathrm{mg} / \mathrm{kg}$ & Tidak ada & Maksimal 0,50 \\
\hline $\begin{array}{l}\text { Cemaran mikroba } \\
\text { - Angka lempeng total (ALT) } \\
\text { - E. Coli } \\
\text { - Kapang }\end{array}$ & $\begin{array}{l}\text { Koloni/g } \\
\text { Koloni/g } \\
\text { Koloni/g }\end{array}$ & $\begin{array}{l}6,4 \times 10^{2} \\
\text { Tidak ada } \\
10\end{array}$ & $\begin{array}{c}10^{6} \\
10 \\
10^{4}\end{array}$ \\
\hline $\begin{array}{l}\text { PENERAPAN } \quad \text { GMP } \\
\text { PERENCANAAN DAN } \\
\text { HACCP (Hazard Analysis Critical Control } \\
\text { Point) PRODUK OLAHAN } \\
\text { TRADISIONAL (Mochi) }\end{array}$ & & \multicolumn{2}{|c|}{ WILDAN WIBAWA PERDANA } \\
\hline
\end{tabular}


Tabel 18. Hasil Pengujian Cemaran Fisik, Kimia dan Mikroba Pada Gula Pasir $\left({ }^{*}\right)$

\begin{tabular}{|l|c|c|c|}
\hline \multicolumn{1}{|c|}{ Parameter } & Satuan & $\begin{array}{c}\text { Hasil } \\
\text { Pengujian }\end{array}$ & $\begin{array}{c}\text { SNI No. 01- } \\
\text { 3140-2001 }\end{array}$ \\
\hline $\begin{array}{l}\text { Cemaran Fisik } \\
\text { - Benda asing } \\
\text {-Serangga dalam bentuk stadia dan potongan- } \\
\text { potongannya }\end{array}$ & - & $\begin{array}{c}\text { Tidak ada } \\
\text { Tidak ada }\end{array}$ & $\begin{array}{c}\text { Tidak ada } \\
\text { Tidak ada }\end{array}$ \\
\hline Cemaran logam - Timbal (Pb) & $\mathrm{mg} / \mathrm{kg}$ & Tidak ada & Maksimal 2,0 \\
\hline Cemaran arsen (As) & $\mathrm{mg} / \mathrm{kg}$ & Tidak ada & Maksimal 1,0 \\
\hline $\begin{array}{l}\text { Menurut Sapers et al. (2006) } \\
\text { menyimpulkan ada empat faktor yang }\end{array}$
\end{tabular}

menyimpulkan ada empat faktor yang menjadi penyebab utama kasus keracunan pangan yaitu pengawasan mutu air, lemahnya tindakan dalam manajemen hama atau hewan pengganggu, fasilitas dan peralatan yang tidak saniter, serta kurangnya penerapan bygiene. Peralatan yang digunakan CV. Ruyaprima Utama terbuat dari bahan anti karat. Terjadinya kontaminasi kemungkinan pada saat penimbangan bahan baku, pembentukan adonan mochi dan pengemasan produk. Hal ini dapat diminimalisasi dengan menerapkan SSOP.

Kajian bahaya (analisis bahaya) terhadap proses produksi mochi serta tindakan pencegahannya secara lengkap dapat dilihat pada Tabel 15.

Berdasarkan kajian bahaya tahapan proses yang telah dilakukan, diperoleh bahwa bahaya potensial pada tahapan proses yang signifikan yang perlu dikendalikan adalah :

1. Tahap proses penerimaan tepung ketan, tepung tapioka, dan gula pasir yaitu kemungkinan adanya bahaya fisik berupa potongan benang, plastik, pasir, dan kotoran.

2. Tahap penyimpanan bahan-bahan di gudang penyimpanan (sementara) yaitu kemungkinan adanya bahaya fisik berupa kontaminasi dari kecoa, lalat, serangga, dan adanya kemungkinan bahaya kimia berupa residu sanitizer.

3. Tahap proses penimbangan bahan baku kemungkinan adanya bahaya biologi berupa kontaminasi bakteri patogen, debu, dan kotoran dari pekerja/karyawan.

4. Tahap proses pencetakan kemungkinan adanya bahaya biologi berupa

\footnotetext{
PENERAPAN

GMP PERENCANAAN PELAKSANAAN HACCP (Hazard Analysis Critical Contro Point) PRODUK OLAHAN PANGAN TRADISIONAL (Mochi)
}

5. Tahap proses pengemasan berupa bahaya biologi bakteri patogen yang diakibatkan dari kontaminasi perkerja

Hasil pengujian cemaran mikroba dari beberapa produk mochi yang dihasilkan oleh CV. Ruyaprima Utama menunjukkan bahwa kandungan yang negatif dari bakteri patogen yang diuji yaitu Salmonella, E. Coli, Staphylococcus dan kapang. Sedangkan jumlah angka lempeng total (ALT) menunjukkan sebagian besar $<100$ koloni per gram, hasil ini masih di bawah batas maksimal yang dipersyaratkan sebesar $10^{6} \mathrm{koloni} /$ gram.Data analisis kapang menunjukkan negatif. Bahan baku yang digunakan untuk produksi mochi adalah tepung ketan dan tapioka, gula, kacang tanah, air. Maka pemeriksaan cemaran mikroba untuk setiap hasil produksi mochi tetap perlu dilakukan untuk memastikan bahwa cemaran mikroba yang ada dalam produk mochi berada dalam jumlah yang aman untuk dikonsumsi.

Jumlah angka lempeng total, termasuk kapang adalah merupakan salah satu parameter mutu, bukan merupakan suatu bahaya keamanan pangan, yang mana tinggi rendahnya jumlah angka lempeng total ini akan mempengaruhi umur simpan (daya simpan) dari produk mochi. Semakin tinggi jumlah angka lempeng total ini, maka kemungkinan besar umur simpan produk akan menjadi semakin pendek. Upaya untuk memperkecil jumlah angka lempeng total ini bisa dilakukan dengan menerapkan GMP dan SSOP secara konsisten (Sapers, et. all. 2006). 
7. Menentukan Titik Kendali Kritis atau Critical Control Point (Langkah Ke-7, Prinsip 2 HACCP)

Menurut Ditjen POM, (1996) Identifikasi penentuan titik kendali kritis atau critical control point (CCP) pada proses produksi mochi di CV. Ruyaprima Utama mulai dari penerimaan bahan dan distribusi produk mochi dapat dilihat pada Tabel 19.

Identifikasi dan kajian bahaya pada penerimaan bahan pembuatan mochi yang telah dilakukan, bahwa bahaya potensial pada tahap penerimaan bahan baku tersebut yang signifikan dan perlu dikendalikan.

Tabel 19. Identifikasi Penentuan Titik kendali (CP) dan Titik Kendali Kritis (CCP) pada Proses Produksi Mochi di CV. Ruyaprima Utama

\begin{tabular}{|c|c|c|c|c|c|c|c|c|c|c|c|}
\hline $\begin{array}{l}\text { Tahap } \\
\text { Proses }\end{array}$ & Bahaya & \begin{tabular}{c|} 
Penyebab/ \\
justifikasi bahaya
\end{tabular} & $\begin{array}{l}\text { Peluang } \\
(\mathrm{H}, \mathrm{M}, \mathrm{L})\end{array}$ & $\begin{array}{c}\text { Severyty } \\
(h, m, l)\end{array}$ & $\begin{array}{c}\text { Tindakan } \\
\text { pencegahan/ } \\
\text { pengendalian }\end{array}$ & P1 & P2 & P3 & P4 & $\begin{array}{l}\mathrm{CCP} \\
\mathrm{CP}\end{array}$ & Alasan Keputusan \\
\hline \multirow{3}{*}{$\begin{array}{l}\text { Penerimaan } \\
\text { tepung Ketan }\end{array}$} & B:E. Coli & Tidak ada & - & - & - & - & - & - & - & - & - \\
\hline & $\begin{array}{l}\mathrm{K}: \text { logam } \\
\text { berat dan } \\
\text { arsen }\end{array}$ & 5 & - & 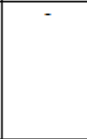 & - & - & - & - & - & - & $\begin{array}{l}\text { Meskipun logam berat dan } \\
\text { arsen termasuk } \\
\text { membahayakan kesehatan, } \\
\text { namun hasil pengujian di } \\
\text { lab tidak ditemukan / } \\
\text { Negative }\end{array}$ \\
\hline & $\begin{array}{l}\text { F: Potongan } \\
\text { benang, tali } \\
\text { serangga }\end{array}$ & \begin{tabular}{|l|} 
Supplier kurang \\
memperhatikan \\
limgkungan \\
produksi
\end{tabular} & $\bar{L}$ & $\bar{L}$ & \begin{tabular}{|l|} 
- Pemeriksaan secara \\
visual dan inspeksi \\
oleh bagian \\
penanggung \\
produksi dan \\
dipisahkan
\end{tabular} & $\mathrm{Ya}_{\mathrm{a}}$ & Tidak & Tidak & - & $\mathrm{CP}$ & $\begin{array}{l}\text { Danpaknya tidak sigifikan } \\
\text { terhadap kesehatan manusia }\end{array}$ \\
\hline \multirow{3}{*}{$\begin{array}{l}\text { Penerimaan } \\
\text { gula pasir }\end{array}$} & B: tidak ada & - & - & - & - & - & - & - & - & - & - \\
\hline & $\mathrm{K}$ : tidak ada & - & - & - & - & - & - & 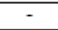 & - & - & - \\
\hline & $\begin{array}{l}\text { F:Potongan } \\
\text { benang, tali } \\
\text { plastik }\end{array}$ & \begin{tabular}{|l|} 
Supplier kurang \\
memperhatikan \\
limgkungan \\
produksi
\end{tabular} & $\mathrm{L}$ & $\mathrm{L}$ & \begin{tabular}{|l|} 
- Pemeriksaan secara \\
visual dan inspeksi \\
oleh bagian \\
penanggung \\
produksi dan \\
dipisahkan
\end{tabular} & $\mathrm{Ya}_{\mathrm{a}}$ & Tidak & Tidak & - & $\mathrm{CP}$ & $\begin{array}{l}\text { Dampaknya tidaksignifikan } \\
\text { terhadap kesehatan manusia }\end{array}$ \\
\hline
\end{tabular}

Tabel19. Identifikasi Penentuan Titik kendali (CP) dan Titik Kendali Kritis (CCP) pada Proses Produksi Mochi di CV. Ruyaprima Utama (Lanjutan)

\begin{tabular}{|c|c|c|c|c|c|c|c|c|c|c|c|}
\hline Tahap/ Proses & Bahaya & \begin{tabular}{|c|} 
Penyebab/ \\
justifikasi bahaya
\end{tabular} & $\begin{array}{l}\text { Peluang } \\
(\mathrm{H}, \mathrm{M}, \mathrm{L})\end{array}$ & $\begin{array}{l}\text { Severyty } \\
(\mathrm{h}, \mathrm{m}, \mathrm{l})\end{array}$ & $\begin{array}{c}\text { Tindakan } \\
\text { pencegahan } \\
\text { pengendalian }\end{array}$ & P1 & P2 & P3 & P4 & $\begin{array}{l}\mathrm{CCP} / \\
\mathrm{CP}\end{array}$ & Alasan Keputusan \\
\hline \multirow{3}{*}{$\begin{array}{l}\text { Penerimaan } \\
\text { tepung } \\
\text { tapioka }\end{array}$} & B:E Coli & Tidak ada & - & - & - & - & - & - & - & - & - \\
\hline & $\begin{array}{l}\text { K: logam } \\
\text { berat dan } \\
\text { arsen }\end{array}$ & - & - & - & - & - & - & - & - & - & $\begin{array}{l}\text { Meskipun logam berat dan } \\
\text { arsen termasuk } \\
\text { membahayakan kesehatan, } \\
\text { namun hasil pengujian di } \\
\text { lab tidak ditemukan / } \\
\text { Negative }\end{array}$ \\
\hline & $\begin{array}{l}\text { F: Potongan } \\
\text { benang, tali } \\
\text { serangga }\end{array}$ & \begin{tabular}{|l|} 
Supplier kurang \\
memperhatikan \\
lingkungan \\
produksi
\end{tabular} & $\mathrm{L}$ & $\mathrm{L}$ & $\begin{array}{l}\text { - Pemeriksaan secara } \\
\text { visual dan inspeksi } \\
\text { oleh bagian } \\
\text { penanggung } \\
\text { produksi dan } \\
\text { dipisahkan }\end{array}$ & $\mathrm{Ya}_{\mathrm{a}}$ & Tidak & Tidak & - & $\mathrm{CP}$ & $\begin{array}{l}\text { Dampakyya tidak sigifikan } \\
\text { terhadap kes ehatan manusia }\end{array}$ \\
\hline \multirow{3}{*}{$\begin{array}{l}\text { Penerimaan } \\
\text { kacang tanah }\end{array}$} & B: Tidak ada & - & - & - & - & - & - & - & - & - & \\
\hline & K: Tidak ada & & - & - & 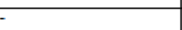 & - & - & - & - & - & \\
\hline & $\begin{array}{l}\text { F: Benda asing } \\
\text { kotoran, tanah) }\end{array}$ & \begin{tabular}{|l|} 
Supplier kurang \\
memperhatikan \\
lingkungan produks
\end{tabular} & $\mathrm{L}$ & $\mathrm{L}$ & $\begin{array}{l}\text { - Pemeriks aan secara } \\
\text { visual dan inspeksi } \\
\text { oleh bagian } \\
\text { penanggung } \\
\text { produksi dan } \\
\text { dipisahkan }\end{array}$ & Ya & Tidak & Tidak & - & $\mathrm{CP}$ & $\begin{array}{l}\text { Dampaknyya tidak sigifikan } \\
\text { terhadap kesehatan manusia }\end{array}$ \\
\hline \multirow{3}{*}{$\begin{array}{l}\text { Penerimaan } \\
\text { Air Untuk } \\
\text { Produksi }\end{array}$} & $B: E$ Coli & - & - & - & - & - & - & - & - & - & - \\
\hline & K : Tidak ada & - & - & - & - & - & - & - & - & - & - \\
\hline & F:Tidak ada & - & - & - & - & - & - & 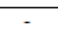 & - & - & - \\
\hline
\end{tabular}

\section{PENERAPAN PERENCANAAN GMP \\ HACCP (Hazard Analysis Critical Control Point) PRODUK OLAHAN PANGAN TRADISIONAL (Mochi)}

WILDAN WIBAWA PERDANA 
Tabel 19. Identifikasi Penentuan Titik kendali (CP) dan Titik Kendali Kritis (CCP) pada Proses Produksi Mochi di CV. Ruyaprima Utama (Lanjutan)

\begin{tabular}{|c|c|c|c|c|c|c|c|c|c|c|c|}
\hline $\begin{array}{l}\text { Tahap } \\
\text { Proses }\end{array}$ & Bahaya & \begin{tabular}{|c|} 
Penyebab/ \\
justifikasi bahaya \\
\end{tabular} & $\begin{array}{l}\text { Peluang } \\
(\mathrm{H}, \mathrm{M}, \mathrm{L})\end{array}$ & $\begin{array}{c}\text { Severyty } \\
(h, m, l)\end{array}$ & $\begin{array}{c}\text { Tindakan } \\
\text { pencegahan } \\
\text { pengendalian }\end{array}$ & P1 & P2 & P3 & P4 & $\begin{array}{l}\mathrm{CCP} / \\
\mathrm{CP}\end{array}$ & Alasan Keputusan \\
\hline \multirow{3}{*}{$\begin{array}{l}\text { Penerimaan } \\
\text { Bahan } \\
\text { Pengemas } \\
\text { karton }\end{array}$} & B : tidak ada & - & - & - & - & & - & - & - & - & - \\
\hline & K : tidak ada & - & - & - & - & & - & - & - & - & - \\
\hline & $\begin{array}{l}\text { F: Debu, } \\
\text { kotoran yang } \\
\text { menempel }\end{array}$ & $\begin{array}{l}\text { Hasilpemeriksaan } \\
\text { dan pemantauan } \\
\text { di rekaman tidak } \\
\text { pernah } \\
\text { ditemukan } \\
\text { benda asing }\end{array}$ & L & $\bar{L}$ & \begin{tabular}{|l} 
Pemeriksaan \\
secara visual dan \\
inspeksilangsung \\
oleh pemilik \\
perusahaan dan \\
penanggung jawab \\
produksi \\
\end{tabular} & Ya & Tidak & Tidak & - & $\mathrm{CP}$ & $\begin{array}{l}\text { Dampaknya tidak } \\
\text { sigifikan terhadap } \\
\text { kesehatan manusia }\end{array}$ \\
\hline \multirow[t]{3}{*}{$\begin{array}{l}\text { Penyimpanan } \\
\text { Bahan-bahan di } \\
\text { Gudang } \\
\text { (sementara) }\end{array}$} & $\begin{array}{l}\text { B } \\
\text { kecoa, lalat, } \\
\text { serangga }\end{array}$ & $\begin{array}{l}\text { Adanya binatang/ } \\
\text { hewan tersebut } \\
\text { dapat membawa } \\
\text { pencemaran }\end{array}$ & $\mathrm{L}$ & $\mathrm{M}$ & $\begin{array}{l}\text { - Lakukan } \\
\text { pengendahian hama } \\
\text { (pest control) } \\
\text { dengan tepat }\end{array}$ & $\mathrm{Ya}$ & Tidak & Ya & 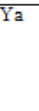 & $\mathrm{CP}$ & $\begin{array}{l}\text { Bakteri penyebab pest } \\
\text { tersebut akan mati } \\
\text { karena pemanasan } \\
\text { pada tahap } \\
\text { penyanggraian, dan }\end{array}$ \\
\hline & $\begin{array}{l}\text { Kas : Residu } \\
\text { Bahn } \\
\text { sanitaiser }\end{array}$ & $\begin{array}{l}\text { Terkontaminasi } \\
\text { oleh residu } \\
\text { bahan sanitaiser }\end{array}$ & L & $\bar{M}$ & $\begin{array}{l}\text { Gunakansanitaiser } \\
\text { yang diizinkan } \\
\text { - Gunakan dosis } \\
\text { yang tepat }\end{array}$ & Ya & Tidak & Tidak & - & $\mathrm{CP}$ & $\begin{array}{l}\text { Penggumaan dan dosis } \\
\text { sanitaiser yang tidak } \\
\text { tepat dapat mengganggu } \\
\text { kesehatan }\end{array}$ \\
\hline & $\begin{array}{l}\text { F: Debu, } \\
\text { kotoran }\end{array}$ & $\begin{array}{l}\text { - Gudang tidak } \\
\text { bersih }\end{array}$ & L & $\mathrm{L}$ & $\begin{array}{l}\text {-Inspeksi dan } \\
\text { pemeriksaan oleh } \\
\text { penanggung jawab } \\
\text { produksi } \\
\text {-Lakukan pembersihan }\end{array}$ & $\mathrm{Ya}$ & Tidak & Tidak & - & $\overline{C P}$ & $\begin{array}{l}\text { Dampaknya tidak } \\
\text { signifikan terhadap } \\
\text { kesehatan manusia }\end{array}$ \\
\hline
\end{tabular}

Tabel 19. Identifikasi Penentuan Titik kendali (CP) dan Titik Kendali Kritis (CCP) pada Proses Produksi Mochi di CV. Ruyaprima Utama (Lanjutan)

\begin{tabular}{|c|c|c|c|c|c|c|c|c|c|c|c|}
\hline Tahap/ Proses & Bahaya & $\begin{array}{c}\text { Penyebab/ } \\
\text { justifikasi bahaya }\end{array}$ & $\begin{array}{l}\text { Peluang } \\
(\mathrm{H}, \mathrm{M}, \mathrm{L})\end{array}$ & $\begin{array}{c}\text { Severyty } \\
(h, m, l)\end{array}$ & $\begin{array}{c}\text { Tindakan } \\
\text { pencegahan } \\
\text { pengendalian }\end{array}$ & P1 & P2 & P3 & P4 & $\begin{array}{l}\mathrm{CCP} \\
\mathrm{CP}\end{array}$ & Alasan Keputusan \\
\hline \multirow{3}{*}{$\begin{array}{l}\text { Penyanggraian } \\
\text { tepung tapioka }\end{array}$} & B: Tidak ada & - & - & - & - & - & - & - & - & - & - \\
\hline & K: Tidak ada & - & - & - & - & - & - & - & - & - & - \\
\hline & \begin{tabular}{|l|}
$\begin{array}{l}\text { F : Benang, } \\
\text { plastik }\end{array}$ \\
\end{tabular} & $\begin{array}{l}\text { Supplier kurang } \\
\text { memperhatikan } \\
\text { lingkungan } \\
\text { produksi }\end{array}$ & $\mathrm{L}$ & $\mathrm{L}$ & $\begin{array}{l}\text { Pemeriks aan dan } \\
\text { inspeksi oleh } \\
\text { penanggung jawab } \\
\text { produksi }\end{array}$ & Ya & Tidak & Tidak & - & $\mathrm{CP}$ & $\begin{array}{l}\text { Dampelunya tidaksigifikan } \\
\text { terhadap kesehatan manusia } \\
\text { - Hasil pemeriksaan } \\
\text { rekaman di perusahaan } \\
\text { tidak ditemukan benda- } \\
\text { benda asing }\end{array}$ \\
\hline \multirow[t]{3}{*}{$\begin{array}{l}\text { Penimbangan } \\
\text { bahan baku } \\
\text { dan bahan } \\
\text { lain untuk } \\
\text { persiapan } \\
\text { formulasi }\end{array}$} & \begin{tabular}{|l|} 
B: \\
salmonella, \\
Staphylacoc \\
cus
\end{tabular} & $\begin{array}{l}\text { Kontaminasibakteri } \\
\text { pada bahan dari } \\
\text { alat dan } \\
\text { personil/ } \\
\text { karyawan }\end{array}$ & $\mathrm{M}$ & $\mathrm{M}$ & $\begin{array}{l}- \text { Penerapan SSOP } \\
\text { (Sanitasi alat) } \\
\text { - Penerapan SSOP } \\
\text { (Kesehatan dan } \\
\text { Higiene Karyawan) }\end{array}$ & $\mathrm{Ya}_{\mathrm{a}}$ & \begin{tabular}{|l|l} 
Tidak \\
\end{tabular} & Tidak & - & $\mathrm{CP}$ & $\begin{array}{l}\text { - Pada tahap berikutnya } \\
\text { ada proses pemasakan }\end{array}$ \\
\hline & K: Tidak & - & - & - & - & - & - & - & - & - & - \\
\hline & $\begin{array}{l}\text { F : Debu, } \\
\text { kotoran } \\
\text { yang } \\
\text { menempel } \\
\text { di karton }\end{array}$ & $\begin{array}{l}\text { Kontaminasi pada } \\
\text { alat yang } \\
\text { digunakan dalam } \\
\text { penimbangan }\end{array}$ & $\mathrm{L}$ & $\mathrm{L}$ & $\begin{array}{l}\text { - Pemeriksaan dan } \\
\text { inspeksi oleh } \\
\text { penanggung jawab } \\
\text { produksi } \\
\text { - Lakukan } \\
\text { pembersihan }\end{array}$ & Ya & \begin{tabular}{|l|l|} 
Tidak \\
\end{tabular} & Tidak & - & $\mathrm{CP}$ & $\begin{array}{l}\text { Dampaknya tidak } \\
\text { signifikan terhadap } \\
\text { kesehatan manusia }\end{array}$ \\
\hline
\end{tabular}

Tabel19. Identifikasi Penentuan Titik kendali (CP) dan Titik Kendali Kritis (CCP) pada Proses Produksi Mochi di CV. Ruyaprima Utama (Lanjutan)

\begin{tabular}{|c|c|c|c|c|c|c|c|c|c|c|c|}
\hline Tahap/ Proses & Bahaya & $\begin{array}{c}\text { Penyebab/ } \\
\text { justifikasi bahaya }\end{array}$ & $\begin{array}{l}\text { Peluang } \\
(\mathrm{H}, \mathrm{M}, \mathrm{L})\end{array}$ & $\begin{array}{c}\text { Severyty } \\
(\mathrm{h}, \mathrm{m}, \mathrm{l})\end{array}$ & $\begin{array}{c}\text { Tindakan } \\
\text { pencegahan } \\
\text { pengendalian }\end{array}$ & P1 & $\mathrm{P} 2$ & P3 & P4 & $\begin{array}{l}\mathrm{CCP} \\
\mathrm{CP}\end{array}$ & Alasan Keputusan \\
\hline \multirow[t]{3}{*}{ Pemanasan gula } & B: Tidak ada & - & - & - & - & - & - & - & - & - & - \\
\hline & K: Tidak ada & - & - & - & - & - & - & - & - & - & - \\
\hline & $\begin{array}{l}F: \text { Debu, } \\
\text { kotoran }\end{array}$ & $\begin{array}{l}\text { Terkontaminasi } \\
\text { olehdebu pada } \\
\text { s aat } \\
\text { penanganan }\end{array}$ & $\overline{\mathrm{L}}$ & $\bar{L}$ & $\begin{array}{l}\text { Inspeksi dan } \\
\text { pemeriksaan oleh } \\
\text { penanggung jawab } \\
\text { produksi } \\
\text { - Lakukan } \\
\text { pembersihan }\end{array}$ & $\mathrm{Ya}$ & Tidak & Tidak & - & $\mathrm{CCP}$ & $\begin{array}{l}\text { Dampaknya tidak } \\
\text { signifikan terhadap } \\
\text { kesehatan manusia }\end{array}$ \\
\hline \multirow{3}{*}{$\begin{array}{l}\text { Penyanggraian } \\
\text { dan } \\
\text { penghancuran } \\
\text { kacang }\end{array}$} & B: Tidak ada & - & - & - & - & - & - & - & - & - & - \\
\hline & K: Tidak ada & - & - & - & - & - & - & - & - & - & - \\
\hline & $\begin{array}{l}\text { F } \\
\text { batu, debu, } \\
\text { kotoran }\end{array}$ & \begin{tabular}{|l} 
- Bahan baku \\
kacang kadang - \\
kadang terdapat \\
batu dan kotoran \\
- Kontaminasi alat \\
dari lingkungan \\
produksi
\end{tabular} & L & L & $\begin{array}{l}\text { Inspeksi dan } \\
\text { pemeriksaan oleh } \\
\text { penanggung jawab } \\
\text { produksi } \\
\text { - Lakukan } \\
\text { pembersihan }\end{array}$ & $\mathrm{Ya}$ & Tidak & Tidak & - & $\mathrm{CP}$ & $\begin{array}{l}\text { Cemaran fisik yang } \\
\text { diperoleh (batu) } \\
\text { dipisahkan dan } \\
\text { dibuang }\end{array}$ \\
\hline
\end{tabular}

Keterangan :Peluang $: \mathrm{H}=$ High, $\mathrm{M}=$ Medium, $\mathrm{L}=$ Low; Severity $: \mathrm{h}=$ high, $\mathrm{m}=$ medium, $\mathrm{l}=$ low;
PENERAPAN
PERENCANAAN
GMP
DAN
PELAKSANAAN
HACCP (Hazard Analysis Critical Control
Point) PRODUK OLAHAN PANGAN
TRADISIONAL (Mochi)

WILDAN WIBAWA PERDANA 
8. Menentukan Batas Kritis (Langkah Ke8, Prinsip 3 HACCP)

Berdasarkan NACMCF, (1998), Hazard Analysis Critical Control Point (HACCP) adalah suatu pendekatan sistem manajemen yang bersifat sistematis untuk mengidentifikasi, mengevaluasi, dan mengendalikan bahaya-bahaya keamanan pangan. Batas kritis adalah kriteria yang membedakan produk atau parameter yang dapat diterima pada produk atau parameter yang tidak dapat diterima/ditolak.Batas kritis ini merupakan toleransi mutlak (absolut) untuk keamanan pangan. Berdasarkan identifikasi bahaya dan titik kendali kritis pada produksi mochi, maka batas kritis untuk mencegah bahaya biologis pada tahap proses pencetakan (CCP1) dapat dilihat pada Tabel20.

Tabel 20. Batas kritis yang ditetapkan pada titik kendali kritis (CCP) untuk produksi mochi di CV. Ruyaprima utama.

\begin{tabular}{|c|l|l|l|}
\hline No & \multicolumn{1}{|c|}{ Jenis Bahaya } & \multicolumn{1}{c|}{$\begin{array}{c}\text { Titik Kendali Kritis } \\
(\mathrm{CCP})\end{array}$} & \multicolumn{1}{c|}{ Batas Kritis } \\
\hline 1. & $\begin{array}{l}\text { Perubahan karakteristik } \\
\text { gula menjadi karamel } \\
\text { (karamelisasi) }\end{array}$ & $\begin{array}{l}\text { Pada tahap pemanasan gula } \\
\text { dengan cara dimasak hingga } \\
\text { mencair }\end{array}$ & $\begin{array}{l}\text { - Suhu } 100-120^{\circ} \mathrm{C} \\
- \text { Waktu pemasakan 30 } \\
\text { menit }\end{array}$ \\
\hline 2. & $\begin{array}{l}\text { Bahaya biologis bakteri } \\
\text { patogen (E. Coli, } \\
\text { Salmonella, Staphyllococcus, } \\
\text { kapang) }\end{array}$ & $\begin{array}{l}\text { Pada tahap pencetakan secara } \\
\text { manual, terjadi kontak dengan } \\
\text { karyawan }\end{array}$ & $\begin{array}{l}\text { Pencetakan dilakukan } \\
\text { dengan waktu maksimal 30 } \\
\text { detik per satu bulatan }\end{array}$ \\
\hline
\end{tabular}

Penetapan batas kritis untuk bahaya bakteri patogen pada proses produksi pembuatan mochi di tahap pemanasan gula dan pencetakan sebagai titik kendali kritis (CCP) ditetapkan berdasarkan pengalaman empiris dan penelitian teknis perusahaan. Pengujian bahaya biologis adanya bakteri patogen (E.coli, Salmonella, Stapabylococcus) dan kapang pada produk mochi untuk memvalidasi batas kritis tersebut dapat dilihat pada Tabel 21.Berdasarkan hasil pengujian bahaya biologis berupa bakteri patogen (E.coli, Salmonella, Stapabylococcus) dan kapang pada produk hasil pencetakan menunjukkan negatif dan kandungan kapangnya sekitar 10 koloni/gram, Hasil pengujian menunjukkan di bawah ambang.

Tabel 21. Hasil Pengujian Cemaran Logam Berat, Arsen pada Bahan Baku Tepung ketan, tepung tapioka, dan Gula serta Bakteri Patogen pada Produk Mochi.

\begin{tabular}{|c|c|c|c|c|c|}
\hline No. & Jenis/Parameter Bahaya & Satuan & Titik Kendali Kritis & $\begin{array}{l}\text { Hasil } \\
\text { Pengujian }\end{array}$ & $\begin{array}{l}\text { Batas } \\
\text { Kritis }\end{array}$ \\
\hline 1. & $\begin{array}{l}\text { Bahaya boil } \\
\text { ogis/ bakteri patogen } \\
\text { - E. Coli } \\
\text { - Salmonella } \\
\text { - Staphylococcus } \\
\text { - Kapang }\end{array}$ & $\begin{array}{l}\text { Koloni/g } \\
\text { Koloni/g } \\
\text { Koloni/g } \\
\text { Koloni/g }\end{array}$ & $\begin{array}{l}\text { Pencetakan } \\
\text { Secara manual (adonan } \\
\text { kontak langsung dengan } \\
\text { karyawan) }\end{array}$ & $\begin{array}{l}\text { Negatif } \\
\text { Negatif } \\
\text { Negatif } \\
10\end{array}$ & $\begin{array}{l}\text { Negatif } \\
\text { Negatif } \\
\text { Negatif } \\
1 \times 10^{4}\end{array}$ \\
\hline
\end{tabular}

9. Menetapkan Prosedur Monitoring (Langkah Ke-9; Prinsip 4 HACCP)

Berdasarkan konsep Bauman, (1995), sistem HACCP sendiri terdiri tiga prinsip, yaitu : prinsip pertama, identifikasi dan pengkajian bahaya yang berhubungan dengan pemanenan hingga penyediaannya; prinsip kedua, penentuan titik kendali kritis dan batas kritis untuk mengendalikan

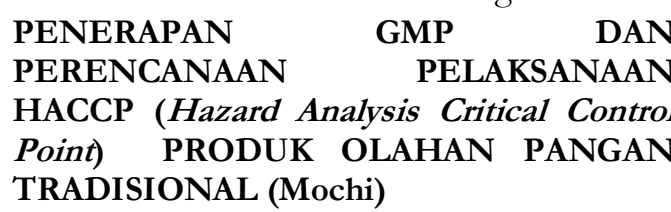

bahaya yang terdidentifikasi, dan prinsip ketiga, menetapkan sistem prosedur untuk memantau titik kendali kritis. Monitoring di CV. Ruyaprima Utama pada titik kendali kritis (CCP) berada di luar kendali adalah melakukan tindakan yang bersifat proaktif dan kreatif. Tindakan proaktif dan kreatif secara lengkap dapat dilihat di program rencana HACCP atau HACCP Plan pada

WILDAN WIBAWA PERDANA 
Tabel 22dan 23. 10. Menetapkan Prosedur Tindakan Koreksi (Langkah Ke-10; Prinsip 5 HACCP)

Menurut Bauman, (1995), Tindakan koreksi adalah segala tindakan yang diambil saat hasil pemantauan/monitoring CCP mengindikasikan hilangnya kendali. Tindakan koreksi pada tahapan pencetakan sebagai titik kendali kritis (CCP) terhadap bahaya bakteri patogen di CV. Ruyaprima Utama adalah sebagai berikut :

a. Perusahaan akan menghentikan proses produksi sementara untuk mengurangi jumlah produk, serta mengevaluasi ketidaksesuaian yang ditemukan oleh penanggung jawab produksi untuk diperbaiki.

b. Produk mochi yang terkotaminasi dipisahkan, kemudian lakukan pengujian terhadap kandungan mikrobiologisme. Produk yang terkontaminasi mikrobiologi akan dimusnahkan oleh perusahaan.

11. Menetapkan Tindakan Verifikasi (Langkah Ke-11; prinsip 6 HACCP)

Menurut Stevenson (1999),

Tindakan verifikasi merupakan suatu kegiatan penerapan metode, prosedur pengujian, analisis, dan evaluasi sebagai tambahan dalam sistem pemantauan untuk mengetahui dan memastikan efektifitas terhadap rencana HACCP. Tindakan verifikasi yang dilakukan pada CV.
Ruyaprima Utama sebagai produsen mochi menyangkut titik kendali kritis (CCP) dan titik kendali (CP) dapat dilihat pada tabel 22 dan 23

Tindakan verifikasi di CV. Ruyaprima Utama pada tahapan proses pemanasan gula dan pencetakan sebagai titik kendali kritis (CCP) adalah sebagai berikut :

Melakukan pemeriksaan catatan (records) titik kendali kritis (CCP) pada tahap pemanasan gula dan pencetakan termasuk catatan penyimpangannya dibandingkan dengan standar batas kritis yang sudah ditetapkan, untuk mengetahui arah kecenderungan perubahan/penyimpangan dari batas kritisnya. Melakukan pemeriksaan catatan laporan hasil kegiatan proses pencetakan terutama pada catatan/ rekaman produk hasil pencetakan yang mengalami cacat atau tidak layak untuk dikonsumsi. Melakukan pengambilan sampel produk akhir hasil secara acak dan berkala untuk diuji dan dianalisis di laboratorium independen yang sudah terakreditasi sesuai dengan spesifikasi standar yang ditetapkan perusahaan atau pemerintah.

Tabel 22. Rencana HACCP (HACCP Plan) Pada Produksi Mochi CV. Ruyaprima Utama

\begin{tabular}{|c|c|c|c|c|c|c|c|c|c|c|}
\hline \multirow[t]{2}{*}{ No. } & \multirow[b]{2}{*}{ ahap Proses } & \multirow{2}{*}{$\begin{array}{l}\text { Bahaya yang } \\
\text { diidentifikasi }\end{array}$} & \multirow[t]{2}{*}{ Batas Kritis } & \multicolumn{4}{|c|}{ Pemantauan (Monitoring) } & \multirow{2}{*}{$\begin{array}{l}\text { Tindakan } \\
\text { Koreksi }\end{array}$} & \multirow{2}{*}{$\begin{array}{c}\text { Tindakan } \\
\text { Verifikasi }\end{array}$} & \multirow{2}{*}{$\begin{array}{l}\text { Prosedur } \\
\text { Rekaman }\end{array}$} \\
\hline & & & & Apa & Bagaiman a & Kapan & Siapa & & & \\
\hline $\mathrm{CCP1}$ & $\begin{array}{l}\text { Pemanasan } \\
\text { pula }\end{array}$ & \begin{tabular}{|l|} 
Perubahan \\
karakteristik gula \\
menjadi karamel \\
(karamelisasi)
\end{tabular} & $\begin{array}{l}\text { Suhu } 80- \\
100^{\circ} \mathrm{C} \\
- \text { Waktu } \\
\text { pemasakan } \\
20 \text { menit }\end{array}$ & $\begin{array}{l}\text { Pemanasan } \\
\text { gula sampai } \\
\text { gula mencair }\end{array}$ & $\begin{array}{l}\text { Dengan } \\
\text { memeriksa } \\
\text { proses } \\
\text { pemasakan } \\
\text { dan } \\
\text { memeriksa } \\
\text { suhu } \\
\text { pemanasan }\end{array}$ & $\begin{array}{l}\text { Selama proses } \\
\text { produksi } \\
\text { pemanasan } \\
\text { gula }\end{array}$ & $\begin{array}{l}\text { Penanggung } \\
\text { jawab } \\
\text { produksi }\end{array}$ & $\begin{array}{l}\text { Bila tidak } \\
\text { sesuai standar } \\
\text { (menjadi } \\
\text { karamel), maka } \\
\text { gula dibuang }\end{array}$ & $\begin{array}{l}\text { Pengaturan } \\
\text { suhu dan } \\
\text { waktu } \\
\text { pemanasan }\end{array}$ & $\begin{array}{l}\text { - Dokumentasi } \\
\text { Laporan } \\
\text { timdakan } \\
\text { koreksi } \\
\text { - Dokumentsi } \\
\text { Laporan } \\
\text { catatan batas } \\
\text { kritis } \\
\text { - Data checklist }\end{array}$ \\
\hline \begin{tabular}{|l|}
$\mathrm{CCP} 2$ \\
\end{tabular} & $\begin{array}{l}\text { Pencetakan } \\
\text { mochi }\end{array}$ & 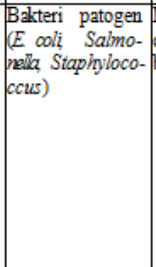 & $\begin{array}{l}\text { Maksimal } 30 \\
\text { detik per satu } \\
\text { bulatan }\end{array}$ & $\begin{array}{l}\text { penotekan } \\
\text { langsung } \\
\text { secara manual } \\
\text { deh tangan } \\
\text { karyawan }\end{array}$ & $\begin{array}{l}\text { Dengan } \\
\text { memeriksa } \\
\text { proses } \\
\text { pencetakan } \\
\text { dan dengan } \\
\text { memeriksa } \\
\text { kebersihan } \\
\text { karyawan } \\
\text { (SSOP } \\
\text { karyawan) }\end{array}$ & $\begin{array}{l}\text { Pencetakan } \\
\text { mochi }\end{array}$ & $\begin{array}{l}\text { Penanggung } \\
\text { jawab } \\
\text { produksi }\end{array}$ & $\begin{array}{l}\text {-Bila tidak } \\
\text { sesuai standar, } \\
\text { maka produk } \\
\text { yang sudah } \\
\text { jadi } \\
\text { dipisahkan' } \\
\text { dikarantina }\end{array}$ & $\begin{array}{l}\text { Uji } \\
\text { mikrobiologi } \\
\text { terhadap } \\
\text { produk akhir }\end{array}$ & $\begin{array}{l}\text { Dokumentasi } \\
\text { Laporan } \\
\text { tindakan } \\
\text { koreksi } \\
\text { - Dokumentsi } \\
\text { Laporan } \\
\text { catatan batas } \\
\text { kritis } \\
\text { - Data checklist }\end{array}$ \\
\hline
\end{tabular}

\section{PENERAPAN PERENCANAAN GMP

WILDAN WIBAWA PERDANA 
Tabel 23. Rencana Pemantauan Control Point (CP) pada Proses Produksi Mochi di Perusahaan CV. Ruyaprima Utama

\begin{tabular}{|c|c|c|c|c|c|c|c|c|c|c|c|c|}
\hline \multirow[b]{2}{*}{ No. } & \multirow{2}{*}{$\begin{array}{c}\text { Bahan } \\
\text { Baku }\end{array}$} & \multirow{2}{*}{$\begin{array}{c}\text { Nomor } \\
\mathrm{CP}\end{array}$} & \multirow{2}{*}{ Bahaya } & \multirow{2}{*}{\begin{tabular}{c|} 
Tindakan \\
pengendalian
\end{tabular}} & \multicolumn{5}{|c|}{ Pemantauan } & \multirow{2}{*}{$\begin{array}{c}\text { Tindakan } \\
\text { koreksi }\end{array}$} & \multirow{2}{*}{$\begin{array}{c}\text { Tanggung } \\
\text { jawab }\end{array}$} & \multirow{2}{*}{$\begin{array}{c}\text { Rekaman/ } \\
\text { Catatan } \\
\text { dokumentasi }\end{array}$} \\
\hline & & & & & Obyek & Lokasi & Prosedur & Frekuensi & Staf/Dept. & & & \\
\hline 1. & $\begin{array}{l}\text { Penerimaan } \\
\text { Tepung } \\
\text { ketan }\end{array}$ & CP-1 & \begin{tabular}{|l} 
- Bakteri \\
patogen \\
(E.Coli, \\
Sabimonella \\
, kapang) \\
-Cemaran \\
logam \\
berat dan \\
arsen \\
- Potongan \\
benang,tali \\
plastic
\end{tabular} & \begin{tabular}{|l|} 
SSOP \\
penerimaan \\
bahan tepung \\
ketan
\end{tabular} & $\begin{array}{l}\text { Tepung } \\
\text { ketan }\end{array}$ & \begin{tabular}{|l|} 
Gudang \\
bahan \\
baku \\
sementara
\end{tabular} & $\begin{array}{l}- \text { Memeriksa } \\
\text { keseuaian } \\
\text { COA } \\
\text { dengan } \\
\text { standar } \\
\text { - Memeriksa } \\
\text { keseuaian } \\
\text { bahan baku } \\
\text { sesuai } \\
\text { standar } \\
\text { secara } \\
\text { visual }\end{array}$ & \begin{tabular}{|l|} 
Setiap \\
penerimaa \\
n bahan \\
baku
\end{tabular} & $\begin{array}{l}\text { Penanggung } \\
\text { jawab } \\
\text { produksi }\end{array}$ & \begin{tabular}{|l} 
Mengembalikan \\
ke supplier \\
- Melakukkan \\
pengujian secara \\
eksternal 6 \\
bulan sekali \\
- kotoran, \\
benang, \\
ataupun plastik \\
yang ada \\
dikumpulkan \\
untuk \\
kemudian \\
dibuang
\end{tabular} & $\begin{array}{l}\text { Penanggung } \\
\text { jawab } \\
\text { produksi }\end{array}$ & $\begin{array}{l}\text { - Dokumentasi } \\
\text { COA } \\
\text { - Dokumentasi } \\
\text { hasil } \\
\text { pengujian } \\
\text {-Dokumentasi } \\
\text { Laporan } \\
\text { tindakan } \\
\text { koreksi } \\
\text { - Data checklist }\end{array}$ \\
\hline 2. & \begin{tabular}{|l|} 
Penerimaan \\
Tepung \\
Tapioka
\end{tabular} & CP-2 & $\begin{array}{l}- \text {-Bakteri } \\
\text { patogen } \\
\text { (E. Coli, } \\
\text { Sabmonella } \\
\text {, hapang) } \\
\text {-Cemaran } \\
\text { logam } \\
\text { berat dan } \\
\text { arsen } \\
\text {-Potongan } \\
\text { benang,tali } \\
\text { plastic }\end{array}$ & \begin{tabular}{|l|} 
SSOP \\
penerimaan \\
bahan tepung \\
tapioka \\
-Tahap \\
berikutnya ada \\
penyanggraian
\end{tabular} & $\begin{array}{l}\text { Tepung } \\
\text { tapioka }\end{array}$ & \begin{tabular}{|l|}
$\begin{array}{l}\text { Gudang } \\
\text { bahan } \\
\text { baku } \\
\text { sementara }\end{array}$ \\
sema
\end{tabular} & $\begin{array}{l}\text {-Memeriksa } \\
\text { keseuaian } \\
\text { COA } \\
\text { dengan } \\
\text { standar } \\
\text {-Memeriksa } \\
\text { keseuaian } \\
\text { bahan } \\
\text { baku } \\
\text { sesuai } \\
\text { standar } \\
\text { secara } \\
\text { visual }\end{array}$ & \begin{tabular}{|l|} 
Setiap \\
penerimaan \\
bahan baku
\end{tabular} & $\begin{array}{l}\text { Penanggung } \\
\text { jawab } \\
\text { produksi }\end{array}$ & $\begin{array}{l}\text { - Mengembalikan } \\
\text { ke supplier } \\
\text { - Melakukan } \\
\text { pengujian secara } \\
\text { eksternal } 6 \\
\text { bulan sekali } \\
\\
\text { - kotoran, } \\
\text { benang, } \\
\text { ataupun plastik } \\
\text { yang ada } \\
\text { dikumpulkan } \\
\text { untuk } \\
\text { kemudian } \\
\text { dibuang }\end{array}$ & $\begin{array}{l}\text { Penanggung } \\
\text { jawab } \\
\text { produksi }\end{array}$ & $\begin{array}{l}\text {-Dokumentasi } \\
\text { COA } \\
\text { - Dokumentasi } \\
\text { hasil } \\
\text { pengujian } \\
\text {-Dokumentasi } \\
\text { Laporan } \\
\text { tindakan } \\
\text { koreksi } \\
\text { - Data checklist }\end{array}$ \\
\hline
\end{tabular}

Tabel 23. Rencana Pemantauan Control Point (CP) pada Proses Produksi Mochi di Perusahaan CV. Ruyaprima Utama (Lanjutan)

\begin{tabular}{|c|c|c|c|c|c|c|c|c|c|c|c|c|}
\hline \multirow[b]{2}{*}{ No. } & \multirow{2}{*}{$\begin{array}{c}\text { Bahan } \\
\text { Baku }\end{array}$} & \multirow{2}{*}{$\underset{C P}{\text { Nomor }}$} & \multirow[b]{2}{*}{ Bahaya } & \multirow{2}{*}{$\begin{array}{c}\text { Tindakan } \\
\text { pengendalian }\end{array}$} & \multicolumn{5}{|c|}{ Pemantauan } & \multirow{2}{*}{$\begin{array}{c}\text { Tindakan } \\
\text { koreksi }\end{array}$} & \multirow{2}{*}{$\begin{array}{c}\text { Tanggun } \\
\text { g } \\
\text { jawab }\end{array}$} & \multirow{2}{*}{$\begin{array}{c}\text { Rekaman/ } \\
\text { Catatan } \\
\text { dokumentasi }\end{array}$} \\
\hline & & & & & Obyek & Lokasi & Prosedur & Frekuensi & Staf/Dept. & & & \\
\hline 3. & $\begin{array}{l}\text { Penerimaan } \\
\text { Gula }\end{array}$ & CP-3 & \begin{tabular}{l|}
-Cemaran \\
logam \\
berat \\
dan \\
cemaran \\
arsen \\
-Potongan \\
benang,tali \\
plastik, \\
pasir
\end{tabular} & \begin{tabular}{l|}
-SSOP \\
Penerimaan \\
bahan baku gula \\
-Tahap \\
berikutnya ada \\
pemanasan
\end{tabular} & Gula & \begin{tabular}{|l|} 
Gudang \\
bahan \\
baku \\
sementara
\end{tabular} & $\begin{array}{l}\text { Memeriksa } \\
\text { keseuaian } \\
\text { COA } \\
\text { dengan } \\
\text { standar }\end{array}$ & $\begin{array}{l}\text { Setiap } \\
\text { penerimaan } \\
\text { bahan baku }\end{array}$ & $\begin{array}{l}\text { Penanggung } \\
\text { jawab } \\
\text { produksi }\end{array}$ & $\begin{array}{l}\text { Mengembalikan } \\
\text { ke supplier } \\
\text { Melakukan } \\
\text { pengujian secara } \\
\text { eksternal } 6 \text { bulan } \\
\text { sekali }\end{array}$ & $\begin{array}{l}\text { Penanggung } \\
\text { jawab } \\
\text { produksi }\end{array}$ & $\begin{array}{l}\text { - Dokumentasi } \\
\text { COA } \\
\text { - Dokumentasi } \\
\text { hasil pengujian } \\
\text { - Dokumentasi } \\
\text { Laporan } \\
\text { tindakan } \\
\text { koreksi } \\
\text { - Data checklist }\end{array}$ \\
\hline 4. & $\begin{array}{l}\text { Penerimaan } \\
\text { Kacang } \\
\text { Tanah }\end{array}$ & CP-4 & $\begin{array}{l}\text { Potongan } \\
\text { benang,tali } \\
\text { plastik, batu }\end{array}$ & $\begin{array}{l}\text { SSOP } \\
\text { penerimaan } \\
\text { bahan baku } \\
\text { kacang tanah }\end{array}$ & \begin{tabular}{|l|} 
Kacang \\
tanah
\end{tabular} & \begin{tabular}{|l|}
$\begin{array}{l}\text { Gudang } \\
\text { bahan } \\
\text { baku } \\
\text { sementara }\end{array}$ \\
\end{tabular} & $\begin{array}{l}\text { Memeriksa } \\
\text { keseuaian } \\
\text { bahan baku } \\
\text { sesuai } \\
\text { standar } \\
\text { secara } \\
\text { visual }\end{array}$ & $\begin{array}{l}\text { Setiap } \\
\text { penerimaan } \\
\text { bahan baku }\end{array}$ & $\begin{array}{l}\text { Penanggung } \\
\text { jawab } \\
\text { produksi } \\
\text { dan } \\
\text { karyawan }\end{array}$ & $\begin{array}{l}\text { - kotoran, batu, } \\
\text { benang, ataupun } \\
\text { plastik yang ada } \\
\text { dikumpulkan } \\
\text { untuk kemudian } \\
\text { dibuang }\end{array}$ & $\begin{array}{l}\text { Penanggung } \\
\text { jawab } \\
\text { produksi }\end{array}$ & $\begin{array}{l}\text {-Dokumentasi } \\
\text { Laporan } \\
\text { tindakan } \\
\text { koreksi } \\
\text { - Dokumentasi } \\
\text { Laporan catatan } \\
\text { batas kritis } \\
\text { - Data checklist }\end{array}$ \\
\hline 5. & $\begin{array}{l}\text { Penerimaan } \\
\text { Bahan } \\
\text { pengemas } \\
\text { Kotak } \\
\text { Karton }\end{array}$ & CP-5 & $\begin{array}{l}\text { Fisik } \\
\text { debu, } \\
\text { kotoran }\end{array}$ & $\begin{array}{l}\text {-SSOP Pene } \\
\text { rimaan bahan } \\
\text { pengemas } \\
\text { kotak karton } \\
\text {-Pemeriksaan } \\
\text { bahan kotak } \\
\text { karton yang } \\
\text { masuk }\end{array}$ & $\begin{array}{l}\text { Kotak } \\
\text { karton }\end{array}$ & \begin{tabular}{|l|} 
Gudang \\
bahan \\
baku \\
sementara
\end{tabular} & $\begin{array}{l}\text { Memeriksa } \\
\text { karton } \\
\text { secara } \\
\text { visual }\end{array}$ & \begin{tabular}{|l|} 
Setiap \\
penermaan \\
bahan \\
pengemas \\
kotak \\
karton
\end{tabular} & $\begin{array}{l}\text { Penanggung } \\
\text { jawab } \\
\text { produksi }\end{array}$ & $\begin{array}{l}\text { - Mengembalikan } \\
\text { ke supplier } \\
\text { - Audit supplier }\end{array}$ & $\begin{array}{l}\text { Penanggung } \\
\text { jawab } \\
\text { produksi }\end{array}$ & $\begin{array}{l}\text { - Dokumentasi } \\
\text { Laporan } \\
\text { tindakan koreksi } \\
\text { - Dokumentasi } \\
\text { Laporan catatan } \\
\text { batas kritis } \\
\text { - Data checklist }\end{array}$ \\
\hline
\end{tabular}

Tabel 23. Rencana Pemantauan Control Point (CP) pada Proses Produksi Mochi di Perusahaan CV. Ruyaprima Utama (Lanjutan)

\begin{tabular}{|c|c|c|c|c|c|c|c|c|c|c|c|c|}
\hline \multirow{2}{*}{ No. } & \multirow{2}{*}{$\begin{array}{c}\text { Bahan } \\
\text { Baku }\end{array}$} & \multirow{2}{*}{$\mid \begin{array}{c}\text { Nomor } \\
\mathrm{CP}\end{array}$} & \multirow[b]{2}{*}{ Bahaya } & \multirow{2}{*}{\begin{tabular}{|c|} 
Tindakan \\
pengendalian
\end{tabular}} & \multicolumn{5}{|c|}{ Pemantauan } & \multirow{2}{*}{$\begin{array}{c}\text { Tindakan } \\
\text { koreksi }\end{array}$} & \multirow{2}{*}{$\begin{array}{c}\text { Tanggung } \\
\text { jawab }\end{array}$} & \multirow{2}{*}{$\begin{array}{c}\text { Rekaman/ } \\
\text { Catatan } \\
\text { dokumentasi }\end{array}$} \\
\hline & & & & & Obyek & Lokasi & Prosedur & Frekuensi & Staf/Dept. & & & \\
\hline 6. & $\begin{array}{l}\text { Penyimpa } \\
\text { nan Bahan } \\
\text { baku } \\
\text { sementara }\end{array}$ & CP-6 & $\begin{array}{l}\text { Biologis : } \\
\text { kecoa, } \\
\text { serangga } \\
\text { - Residu } \\
\text { bahan } \\
\text { sanitaiser } \\
\text { - Fisik: } \\
\text { debu, } \\
\text { kotoran }\end{array}$ & \begin{tabular}{|l|} 
- SSOP \\
penyimpanan \\
bahan baku \\
dan bahan \\
laimnya \\
- Lakukan pest \\
Control
\end{tabular} & \begin{tabular}{|l|} 
Bahan \\
Baku dan \\
produk
\end{tabular} & \begin{tabular}{|l|} 
Gudang \\
Penyimp- \\
anan \\
bahan \\
baku \& \\
produk
\end{tabular} & $\begin{array}{l}\text { Memeriksa } \\
\text { gudang } \\
\text { penyimpanan }\end{array}$ & $\begin{array}{l}\text { Sebelum } \\
\text { produksi }\end{array}$ & $\begin{array}{l}\text { Karyawan } \\
\text { produksi } \\
\text { \& } \\
\text { Penanggung } \\
\text { jawab } \\
\text { produksi }\end{array}$ & $\begin{array}{l}\text { Perketat } \\
\text { praktek } \\
\text { Penyimpanan } \\
\text { Bahan sesuai } \\
\text { GMP dan SSOP } \\
\text { - Perketat } \\
\text { penerapan } \\
\text { Pengendalian } \\
\text { Serangga }\end{array}$ & $\begin{array}{l}\text { Karyawan } \\
\text { produksi } \\
\& \\
\text { Penanggung } \\
\text { jawab } \\
\text { produksi }\end{array}$ & $\begin{array}{l}\text { Dokumen } \\
\text { jadwal piket } \\
\text { pembersihan } \\
\text { gudang }\end{array}$ \\
\hline 7 & Penimbangan & CP-7 & $\begin{array}{l}\text {-Bakteri } \\
\text { patogen } \\
\text {-Ceceran } \\
\text { bahan baku }\end{array}$ & \begin{tabular}{|l|}
-SSOP \\
(Kesehatan \& \\
Higiene \\
Pekerja) \\
- SSOP \\
Sanitasi \\
\end{tabular} & \begin{tabular}{|l|} 
- Pekerja \\
karyawan \\
-Alat tim- \\
bangan \\
dan meja
\end{tabular} & \begin{tabular}{|l|} 
Ruang \\
proses \\
produksi
\end{tabular} & \begin{tabular}{|l|} 
- Memeriksa \\
kesehatan \\
karyawan \\
\\
- memakai \\
Perlengkapan \\
Produksi \\
(masker, \\
sarung tangan \\
,dll) \\
- Memeriksa \\
kondisi \\
kebersihan \\
alat dan tempat \\
penimbangan
\end{tabular} & \begin{tabular}{|l} 
- Minimal 1 \\
tahun \\
sekali \\
\\
-Setiap \\
Produksi \\
-Setiap \\
Sesusah dan \\
sebelum \\
Produksi
\end{tabular} & \begin{tabular}{|l|} 
Karyawan \\
produksi \& \\
Penanggung \\
jawab \\
produksi \\
\end{tabular} & $\begin{array}{l}\text { - Perketat praktek } \\
\text { higiene dan } \\
\text { kesehatan } \\
\text { pekerja } \\
\text { - Beri teguran } \\
\text { kepada } \\
\text { karyawan atau } \\
\text { beri pelatihan } \\
\text { higiene dan } \\
\text { sanitasi }\end{array}$ & $\begin{array}{l}\text { Penanggung } \\
\text { jawab } \\
\text { produksi }\end{array}$ & $\begin{array}{l}\text {-Dokumen } \\
\text { jadwal piket } \\
\text { sebelum dan } \\
\text { sesudah } \\
\text { produksi } \\
\text {-Draft ceklis } \\
\text { pembersihan } \\
\text { alat }\end{array}$ \\
\hline
\end{tabular}


Tabel 23. Rencana Pemantauan Control Point (CP) pada Proses Produksi Mochi di Perusahaan CV. Ruyaprima Utama (Lanjutan)

\begin{tabular}{|c|c|c|c|c|c|c|c|c|c|c|c|c|}
\hline \multirow{2}{*}{ No. } & \multirow{2}{*}{$\begin{array}{c}\text { Bahan } \\
\text { Baku }\end{array}$} & \multirow{2}{*}{$\begin{array}{c}\text { Nomor } \\
\text { CP }\end{array}$} & \multirow{2}{*}{ Bahaya } & \multirow{2}{*}{$\begin{array}{c}\text { Tindakan } \\
\text { pengendalian }\end{array}$} & \multicolumn{5}{|c|}{ Pemantauan } & \multirow{2}{*}{$\begin{array}{c}\text { Tindakan } \\
\text { koreksi }\end{array}$} & \multirow{2}{*}{$\begin{array}{c}\text { Tanggung } \\
\text { jawab }\end{array}$} & \multirow{2}{*}{$\begin{array}{c}\text { Rekaman/ } \\
\text { Catatan } \\
\text { dokumentasi }\end{array}$} \\
\hline & & & & & Obyek & Lokasi & Prosedur & Frekuensi & Staf/Dept. & & & \\
\hline 8. & \begin{tabular}{|l|} 
Penyanggraia \\
n tepung \\
tapioka
\end{tabular} & CP-8 & $\begin{array}{l}\text { - Bakteri } \\
\text { patogen } \\
\text {-Fisk: } \\
\text { Benang, } \\
\text { Plastk }\end{array}$ & \begin{tabular}{|l|}
-Pemeriksaan \\
dan inpeksi \\
secara visual \\
-SSOP \\
(Kesehatan \& \\
Higiene \\
Pekerja) \\
-SSOP(Sanitasi: \\
alat \& ruangan
\end{tabular} & $\begin{array}{l}\text { - Tepung } \\
\text { tapioka } \\
\text { - Pekerja/ } \\
\text { karyawan } \\
\text { - Wadah } \\
\text { yang di- } \\
\text { gunakan }\end{array}$ & \begin{tabular}{|c|} 
Ruang \\
proses \\
produks
\end{tabular} & \begin{tabular}{|l|}
-Memeriksa \\
secara visual \\
:pada bahan baku \\
-Memeriksa \\
kesehatan \\
karyawan \\
-Memeriksa \\
kondisi \\
kebersihan alat
\end{tabular} & \begin{tabular}{|l} 
Setiap \\
Sebelum \\
dan sesudah \\
\\
-Minimal 1 \\
tahun sekali \\
-Setiap \\
Sebelum \\
dan sesudah
\end{tabular} & $\begin{array}{l}\text { Karyawan } \\
\text { dan } \\
\text { Penanggung } \\
\text { jawab } \\
\text { produksi }\end{array}$ & \begin{tabular}{|l}
-memisahkan \\
benang dan plastik \\
- Perketat praktek \\
higiene dan \\
kesehatan pekerja \\
- Beri teguran \\
kepada karyawan \\
atau beri pelatihan \\
higiene dan sanitasi
\end{tabular} & $\begin{array}{l}\text { Penanggung } \\
\text { jawab } \\
\text { produksi }\end{array}$ & $\begin{array}{l}\text { - Dokumentasi hasil } \\
\text { pemeriksaan } \\
\text { Kesehatan } \\
\text { karyawan } \\
\text { - Dokumentasi log } \\
\text { book hasil } \\
\text { pemeriksaan alat }\end{array}$ \\
\hline 9. & $\begin{array}{l}\text { Penyanggraia } \\
\text { n dan } \\
\text { penghancuran } \\
\text { kacang tanah }\end{array}$ & CP-9 & $\begin{array}{l}\text { - Bakteri } \\
\text { patogen } \\
\text {-Fisik: } \\
\text { Benang, } \\
\text { Plastk }\end{array}$ & \begin{tabular}{|l|} 
Pemeriksaan \\
dan inpeksi \\
secara visual \\
-SSOP \\
Kesehatan \& \\
Higiene \\
Pekerja) \\
- SSOP \\
(Sanitasi alat \& \\
fuangan)
\end{tabular} & $\begin{array}{l}\text { - Kacang } \\
\text { tanah } \\
\\
- \text { Pekerja } \\
\text { karyawan } \\
\text { - Wadah } \\
\text { yang di- } \\
\text { gunakan }\end{array}$ & \begin{tabular}{|l|} 
Ruang \\
proses \\
produks
\end{tabular} & $\begin{array}{l}\text {-Memeriksa } \\
\text { - Mecara visual } \\
\text { :pada bahan baku } \\
\text {-Memeriksa } \\
\text { kesehatan } \\
\text { karyawan } \\
\text {-Memeriksa } \\
\text { kondisi } \\
\text { kebersihan alat }\end{array}$ & $\begin{array}{l}\text { Setiap } \\
\text { Sebelum } \\
\text { dan sesudah } \\
\text {-Minimal 1 } \\
\text { tahun sekali } \\
\text {-Setiap } \\
\text { Sebelum } \\
\text { dan sesudah }\end{array}$ & $\begin{array}{l}\text { Karyawan } \\
\text { dan } \\
\text { Penanggung } \\
\text { jawab } \\
\text { produksi }\end{array}$ & $\begin{array}{l}\text { - memisahkan } \\
\text { benang dan plastik } \\
\text { - Perketat praktek } \\
\text { higiene dan } \\
\text { kesehatan pekerja } \\
\text { - Beri teguran } \\
\text { kepada karyawan } \\
\text { atau beri pelatihan } \\
\text { higiene dan sanitasi }\end{array}$ & $\begin{array}{l}\text { Penanggung } \\
\text { jawab } \\
\text { produksi }\end{array}$ & $\begin{array}{l}\text { - Dokumentasi hasil } \\
\text { pemeriksaan } \\
\text { kesehatan } \\
\text { karyawan } \\
\text { - Dokumentasi log } \\
\text { book hasil } \\
\text { pemeriksaan alat }\end{array}$ \\
\hline 10. & \begin{tabular}{|l|} 
Pencampura \\
n tepung \\
ketan dan \\
air panas \\
(wajan 1) \\
\end{tabular} & CP-10 & $\begin{array}{l}\text { - Bakteri } \\
\text { patogen } \\
\text { - Ceceran } \\
\text { bahan } \\
\text { kimia } \\
\text { pembersih }\end{array}$ & \begin{tabular}{|l|} 
SSOP \\
(Kesehatan \& \\
Higiene \\
Pekerja) \\
- SSOP \\
(Sanitasi alat \& \\
ruangan)
\end{tabular} & $\begin{array}{l}\text { - Pekerja' } \\
\text { karyawan } \\
\\
\text { - Wadah } \\
\text { yang di- } \\
\text { gunakan }\end{array}$ & \begin{tabular}{|c|} 
Ruang \\
proses \\
produks
\end{tabular} & $\begin{array}{l}\text {-Memeriksa } \\
\text { kesehatan } \\
\text { karyawan } \\
\text {-Memeriksa } \\
\text { kondisi } \\
\text { kebersihan } \\
\text { alat }\end{array}$ & $\begin{array}{l}\text {-Minimal 1 } \\
\text { tahun sekali } \\
\\
\text {-Setiap } \\
\text { Sebelum dan } \\
\text { sesudah }\end{array}$ & $\begin{array}{l}\text { Karyawan } \\
\text { dan } \\
\text { Penanggung } \\
\text { jawab } \\
\text { produksi }\end{array}$ & $\begin{array}{l}\text { - Perketat praktek } \\
\text { higiene dan } \\
\text { kesehatan pekerja } \\
\text { - Beri teguran } \\
\text { kepada karyawan } \\
\text { atau beri pelatihan } \\
\text { higiene dan sanitasi }\end{array}$ & $\begin{array}{l}\text { Penanggung } \\
\text { jawab } \\
\text { produksi }\end{array}$ & $\begin{array}{l}\text { - Dokumentasi } \\
\text { hasil pemeriksaan } \\
\text { Kesehatan } \\
\text { karyawan } \\
\text { - Dokumentasi log } \\
\text { book hasil } \\
\text { pemeriksaan alat }\end{array}$ \\
\hline
\end{tabular}

Tabel 23. Rencana Pemantauan Control Point (CP) pada Proses Produksi Mochi di Perusahaan CV. Ruyaprima Utama (Lanjutan)

\begin{tabular}{|c|c|c|c|c|c|c|c|c|c|c|c|c|}
\hline \multirow[b]{2}{*}{ No. } & \multirow{2}{*}{$\begin{array}{l}\text { Bahan } \\
\text { Baku }\end{array}$} & \multirow{2}{*}{$\begin{array}{c}\text { Nomor } \\
\mathrm{CP}\end{array}$} & \multirow{2}{*}{ Bahaya } & \multirow{2}{*}{$\begin{array}{c}\text { Tindakan } \\
\text { pengendalian }\end{array}$} & \multicolumn{5}{|c|}{ Pemantauan } & \multirow{2}{*}{$\begin{array}{c}\text { Tindakan } \\
\text { koreksi }\end{array}$} & \multirow{2}{*}{$\begin{array}{c}\text { Tanggung } \\
\text { jawab }\end{array}$} & \multirow{2}{*}{$\begin{array}{c}\text { Rekamana } / \\
\text { Catatan } \\
\text { dokumentasi }\end{array}$} \\
\hline & & & & & Obyek & Lokasi & Prosedur & Frekuensi & Staf/Dept. & & & \\
\hline 11. & \begin{tabular}{|l} 
Pencamp \\
uran \\
(wajan2)
\end{tabular} & CP-11 & $\begin{array}{l}\text { - Bakteri } \\
\text { patogen } \\
\text { - Ceceran } \\
\text { bahan kimia } \\
\text { pembersih }\end{array}$ & \begin{tabular}{|l|}
-SSOP \\
(Kesehatan \& \\
Higiene \\
Pekerja) \\
- SSOP \\
(Sanitasi alat \& \\
fuangan)
\end{tabular} & \begin{tabular}{|l|} 
- Pekerja \\
karyawan \\
- Wadah \\
yang di- \\
gunakan
\end{tabular} & \begin{tabular}{|l|} 
Ruang \\
proses \\
produksi
\end{tabular} & $\begin{array}{l}\text {-Memeriksa } \\
\text { kesehatan } \\
\text { karyawan } \\
\text {-Memeriksa } \\
\text { kondisi } \\
\text { kebersihan } \\
\text { alat }\end{array}$ & $\begin{array}{l}\text {-Mimimal 1 } \\
\text { tahun sekali } \\
\text {-Setiap } \\
\text { Sebelum } \\
\text { dan sesudah }\end{array}$ & \begin{tabular}{|l|} 
Karyawan \\
dan \\
Penanggung \\
jawab \\
produksi \\
\end{tabular} & $\begin{array}{l}\text { - Perketat praktek } \\
\text { higiene dan } \\
\text { kesehatan pekerja } \\
\text { - Beri teguran } \\
\text { kepada karyawan } \\
\text { atau beri pelatihan } \\
\text { higiene dan } \\
\text { sanitasi }\end{array}$ & $\begin{array}{l}\text { Penanggung } \\
\text { jawab } \\
\text { produksi }\end{array}$ & $\begin{array}{l}\text { Dokumentasi hasil } \\
\text { pemeriksaan } \\
\text { kesehatan } \\
\text { karyawan } \\
\text { Dokumentasi log } \\
\text { book hasil } \\
\text { pemeriksaan alat }\end{array}$ \\
\hline 12. & $\begin{array}{l}\text { Pengema } \\
\text { san }\end{array}$ & CP-12 & -Debu & \begin{tabular}{|l|}
-SSOP \\
Kesehatan \& \\
Higiene \\
Pekerja) \\
$\quad$ SSOP(Sani- \\
- tasi alat \& \\
ruangan)
\end{tabular} & \begin{tabular}{|l|} 
- Pekerja \\
karyawan
\end{tabular} & $\begin{array}{l}\text { Ruang } \\
\text { Pengemas } \\
\text { an }\end{array}$ & \begin{tabular}{|l}
-Memeriksa \\
kesehatan \\
karyawan \\
-Memeriksa \\
kondisi \\
kebersihan \\
alat dan \\
ruangan, serta \\
bahan \\
pengemas
\end{tabular} & $\begin{array}{l}\text {-Pada proses } \\
\text { pengemasan } \\
\text { berlangsung }\end{array}$ & \begin{tabular}{|l|} 
Karyawan \\
dan \\
Penanggung \\
jawab \\
produksi \\
\end{tabular} & $\begin{array}{l}\text {-Memeriksa kondisi } \\
\text { kebersihan alat dan } \\
\text { ruangan, serta bahan } \\
\text { pengemas }\end{array}$ & $\begin{array}{l}\text { Penanggung } \\
\text { jawab } \\
\text { produksi }\end{array}$ & $\begin{array}{l}\text { Dokumentasi log } \\
\text { book hasil } \\
\text { pemeriksaan } \\
\text { pengemasan }\end{array}$ \\
\hline 13. & \begin{tabular}{|l|} 
Penyimpa \\
nan \\
sementara \\
produk \\
akhir
\end{tabular} & CP-13 & $\begin{array}{l}\text { - Biologis : } \\
\text { kecoa,serangga } \\
\text { - Residu } \\
\text { bahan } \\
\text { sanitaiser } \\
\text { - Fisik: } \\
\text { debu, } \\
\text { kotoran } \\
\end{array}$ & \begin{tabular}{|l|} 
- SSOP \\
penyimpanan \\
bahan baku \\
dan bahan \\
laimnya \\
- Lakukan pest \\
Control
\end{tabular} & \begin{tabular}{|l|} 
Bahan \\
Baku dan \\
produk
\end{tabular} & \begin{tabular}{|l|} 
Gudang \\
Penyimp- \\
anan \\
bahan \\
baku \& \\
produk
\end{tabular} & $\begin{array}{l}\text { Memeriksa } \\
\text { gudang } \\
\text { penyimpanan }\end{array}$ & $\begin{array}{l}\text { Sebelum } \\
\text { produksi }\end{array}$ & $\begin{array}{l}\text { Karyawan } \\
\text { produksi } \\
\text { \& } \\
\text { Penanggung } \\
\text { jawab } \\
\text { produksi }\end{array}$ & \begin{tabular}{|l|}
-Perketat praktek \\
Penyimpanan \\
bahan sesuai GMP \\
dan SSOP \\
- Perketat \\
penerapan \\
pengendalian \\
Serangga \\
\end{tabular} & \begin{tabular}{|l|} 
Karyawan \\
produksi \\
$\&$ \\
Penanggung \\
jawab \\
produksi
\end{tabular} & $\begin{array}{l}\text { Dokumen jadwal } \\
\text { piket } \\
\text { pembersihan } \\
\text { gudang }\end{array}$ \\
\hline
\end{tabular}

Tabel 23. Rencana Pemantauan Control Point (CP) pada Proses Produksi Mochi di Perusahaan CV. Ruyaprima Utama (Lanjutan)

\begin{tabular}{|c|c|c|c|c|c|c|c|c|c|c|c|c|}
\hline \multirow[b]{2}{*}{$\mathrm{I}_{0 .}$} & \multirow{2}{*}{$\begin{array}{l}\text { Bahan } \\
\text { Balill }\end{array}$} & \multirow{2}{*}{$\begin{array}{c}\text { Yomor } \\
\mathrm{CP}\end{array}$} & \multirow[b]{2}{*}{ Bahayja } & \multirow{2}{*}{$\begin{array}{c}\text { Timdakan } \\
\text { pengendalian }\end{array}$} & \multicolumn{5}{|c|}{ Pemantauan } & \multirow{2}{*}{$\begin{array}{c}\text { Timdakan } \\
\text { kooreksi }\end{array}$} & \multirow{2}{*}{$\begin{array}{c}\text { Tanggung } \\
\text { jarrab }\end{array}$} & \multirow{2}{*}{$\begin{array}{c}\text { Rekimman/ } \\
\text { Catatan } \\
\text { dokumentasi }\end{array}$} \\
\hline & & & & & Obyek & Lokasi & Prosedur & Fretuensi & StafiDept, & & & \\
\hline 14. & $\begin{array}{l}\text { Penginim } \\
\text { and dan } \\
\text { Distrousi }\end{array}$ & $C P \cdot 14$ & $\begin{array}{l}\text { Fisil: } \\
\text { debul } \\
\text { danl } \\
\text { chotorall }\end{array}$ & 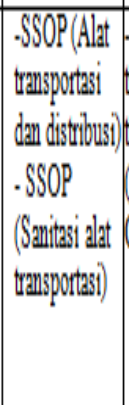 & 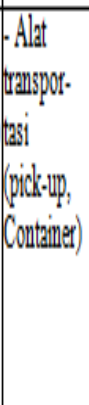 & 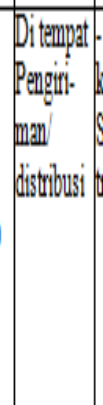 & 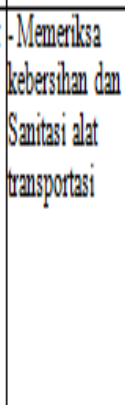 & 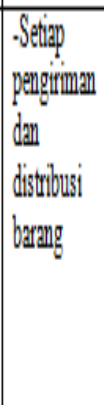 & $\begin{array}{l}\text { Karyarian } \\
\text { dan } \\
\text { Penangegum } \\
\text { gasarab } \\
\text { produlusi }\end{array}$ & 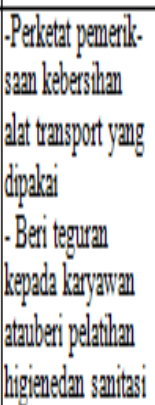 & $\begin{array}{l}\text { Penangegug } \\
\text { avivab } \\
\text { produlasi }\end{array}$ & 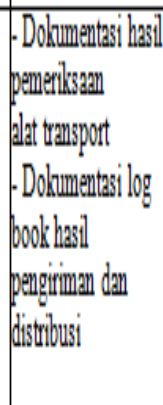 \\
\hline
\end{tabular}


12. Menetapkan Sistem Dokumentasi (Langkah Ke-12; Prinsip 7 HACCP)

Penentuan sistem dokumentasi bertujuan untuk menjaga dan mempermudah pengendalian atau pembaharuan catatan dan rencana HACCP.Pencatatan yang efisien dan akurat di perusahaan sangat penting dalam penerapan sistem HACCP. Penerapan sistem HACCP dalam proses produksi mochi di CV. Ruyaprima Utama harus diikuti dengan dokumentasi mengenai penerapan HACCP sesuai dengan SNI.01.4852-1998 (BSN, 1998) dan Pedoman BSN 1004 : 2002 (BSN, 2002). Dokumentasi ini berfungsi sebagai acuan dan bukti penerapan HACCP.

Dokumentasi tertulis program HACCP diharapkan dapat menjamin bahwa program tersebut dilaksanakan, diperiksa kembali dan dipertahankan selama periode tertentu. Menurut Thaheer
(2005), tujuan penerapan sistem dokumentasi dan pencatatan adalah : (1) Bukti keamanan produk berkaitan dengan prosedur dan proses yang ada, (2) Jaminan pemenuhan terhadap peraturan, (3) Kemudahan pelacakan/kemamputelusuran dan peninjauan catatan, (4) Dokumentasi data pengukuran menuju catatan permanen mengenai keamanan produk pangan,(5) Merupakan sumber tinjauan data yang diperlukan apabila ada audit HACCP, (6) Rekaman/catatan HACCP dapat lebih memusatkan pada isu keamanan pangan sehingga mempercepat identifikasi masalah, dan (7) Membantu mengidentifikasi lot ingredient, bahan pengemas, dan produk akhir apabila timbul masalah keamanan pangan yang segera dilakukan penarikan produk dari pasaran. Dokumen dan rekaman pada penerapan HACCP di CV. Ruyaprima Utama dapat dilihat pada Tabel 24.

Tabel 24. Dokumen dan rekaman pada penerapan sistem HACCP di CV. Ruyaprima Utama

\begin{tabular}{|l|l|l|l|}
\hline \multicolumn{1}{|c|}{ Contoh } & \multicolumn{1}{|c|}{ Deskripsi } & \multicolumn{1}{c|}{ Contoh } & \multicolumn{1}{c|}{ Deskripsi } \\
\hline $\begin{array}{l}\text { Manual } \\
\text { HACCP }\end{array}$ & $\begin{array}{l}\text { Deskripsi kebijakan dan } \\
\text { strategi pimpinan perusahaan } \\
\text { pada penerapan HACCP }\end{array}$ & $\begin{array}{l}\text { Data hasil } \\
\text { identifikasi } \\
\text { bahaya }\end{array}$ & $\begin{array}{l}\text { Formulir yang telah berisi } \\
\text { daftar potensi bahaya dan } \\
\text { tindakan pencegahannya }\end{array}$ \\
\hline $\begin{array}{l}\text { Prosedur } \\
\text { Pengendalian } \\
\text { Proses }\end{array}$ & $\begin{array}{l}\text { Berisi langkah-langkah } \\
\text { pengendalian proses termasuk } \\
\text { di dalamnya pengendalian } \\
\text { CCP }\end{array}$ & $\begin{array}{l}\text { Catatan suhu } \\
\text { penyanggraian } \\
\text { dan suhu } \\
\text { pemasakan }\end{array}$ & $\begin{array}{l}\text { Formulir pencatatan/ } \\
\text { pendataan suhu } \\
\text { penyanggraian dan } \\
\text { pemasakan yang telah berisi } \\
\text { dan diotorisasi }\end{array}$ \\
\hline $\begin{array}{l}\text { Prosedur } \\
\text { Tindakan } \\
\text { Koreksi }\end{array}$ & $\begin{array}{l}\text { Berisi tahap-tahap yang dilalui } \\
\text { apabila terjadi penyimpangan } \\
\text { proses produksi }\end{array}$ & $\begin{array}{l}\text { Rekaman } \\
\text { langkah tindakan } \\
\text { koreksi }\end{array}$ & $\begin{array}{l}\text { Bukti tindakan koreksi yang } \\
\text { telah dilakukan }\end{array}$ \\
\hline $\begin{array}{l}\text { Prosedur } \\
\text { Internal Audit }\end{array}$ & $\begin{array}{l}\text { Berisi proses verifikasi sistem } \\
\text { HACCP melalui pemeriksaan }\end{array}$ & $\begin{array}{l}\text { Jadwal rencana } \\
\text { audit internal }\end{array}$ & $\begin{array}{l}\text { Formulir jadwal yang telah } \\
\text { diisi dan diotorisasi }\end{array}$ \\
\hline $\begin{array}{l}\text { Prosedur } \\
\text { Pengendalian } \\
\text { Dokumen }\end{array}$ & $\begin{array}{l}\text { Berisi petunjuk pengolahan } \\
\text { dan pengendalian dokumen }\end{array}$ & $\begin{array}{l}\text { Bukti } \\
\text { permintaan } \\
\text { perubahan } \\
\text { dokumen }\end{array}$ & $\begin{array}{l}\text { Formulir permintaan } \\
\text { perubahan dokumen yang } \\
\text { telah diisi }\end{array}$ \\
\hline
\end{tabular}

13. Menetapkan Prosedur Pengaduan Konsumen

Prosedur pengaduan konsumen merupakan persyaratan tambahan yang harus dibuat oleh perusahaan dalam menerapkan sistem HACCP sesuai dengan persyaratan yang ditetapkan dalam SNI.01.4852-1998 dan Pedoman BSN
1004 : 2002. Metode untuk menerima, menangani pengaduan konsumen dan memberikan penyelesaian terakhir yang terbaik untuk menjawab pengaduan konsumen, yang diterima oleh Bagian Pemasaran. Pengaduan konsumen di CV. Ruyaprima Utama ditangani oleh perusahaan dengan tahapan sebagai berikut

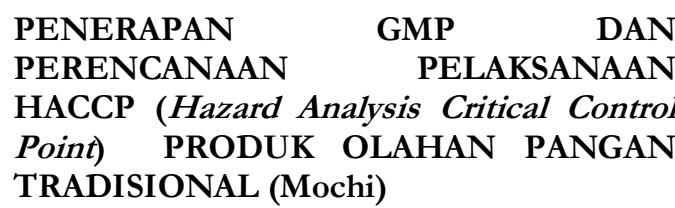

PENERAPAN PERENCANAAN$$
\text { GMP }
$$

\section{WILDAN WIBAWA PERDANA}


: (1) Bagian Pemasaran menerima pengaduan dari konsumen dan dituangkan dalam Complaint Report, kemudian disampaikan ke bagian penanggung jawab produksi; (2) Bagian penanggung jawab produksi mengidentifikasi produk yang dikeluhkan berdasarkan : nama produk, jenis kemasan, tanggal penerimaan, jumlah dan masalah yang dikeluhkan. Mengevaluasi hal yang dikeluhkan berdasarkan rekaman produksi dan memeriksa sample. Mendiskusikan dengan pemimpin perusahaan untuk tindakan perbaikan dan tanggapan atas keluhan tersebut; (3) Pimpinan perusahaan memutuskan tindakan penyelesaian akhir berdasarkan laporan dari Penanggung Jawab Produksi; (4) Bagian Pemasaran memberikan tanggapan penyelesaian atas pengaduan tersebut kepada konsumen; dan (5) konsumen menerima penyelesaian tersebut, maka kasus ini dinyatakan "selesai" dan bukti rekaman semua pengaduan konsumen disimpan oleh Bagian Pemasaran. Diagram penanganan pengaduan konsumen yang ditangani oleh perusahaan CV. Ruyaprima Utama dapat dilihat pada Gambar 10 .

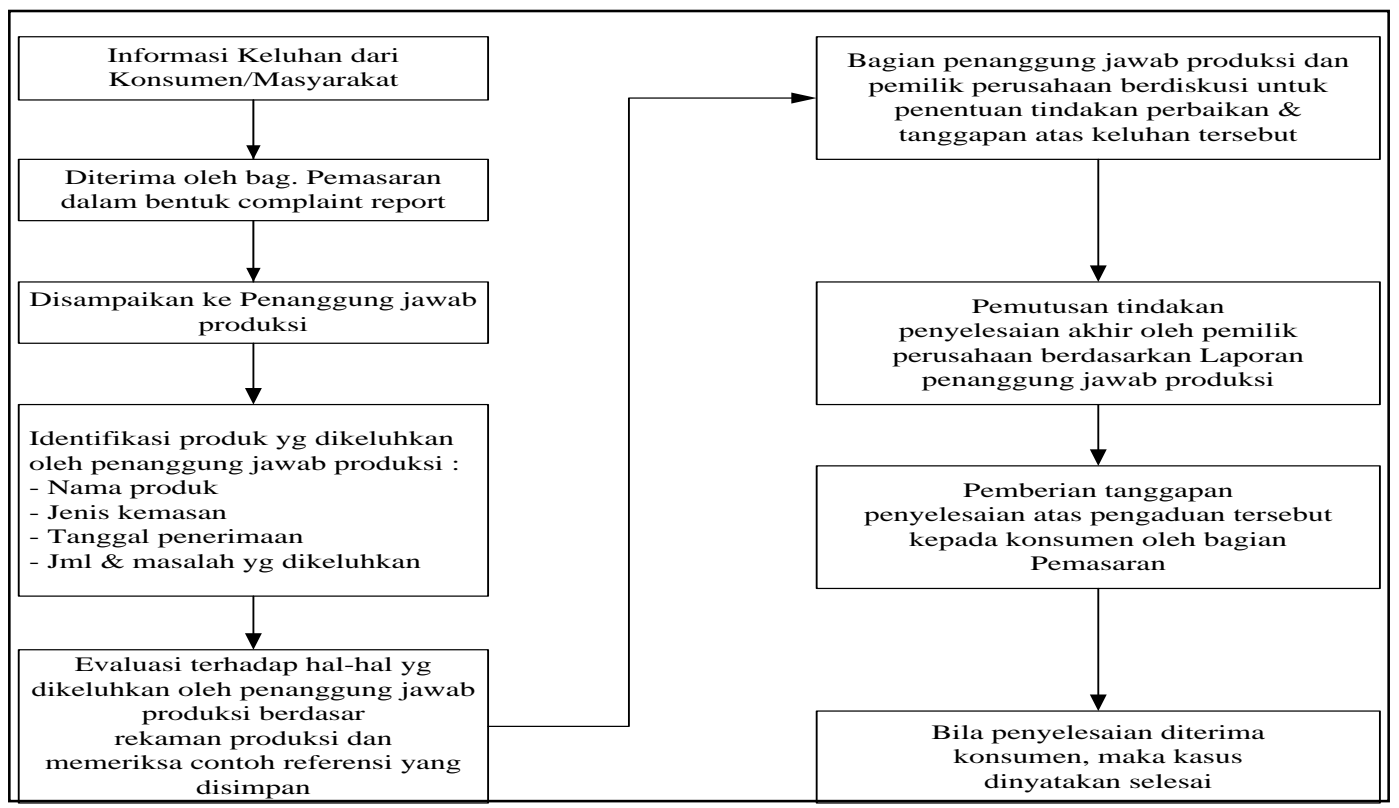

Gambar 10. Diagram Penanganan Pengaduan Konsumen di CV. Ruyaprima Utama

\section{Menetapkan Prosedur Recall}

Prosedur recall juga merupakan persyaratan tambahan yang harus dibuat oleh perusahaan dalam menerapkan sistem HACCP untuk memenuhi persyaratan yang ditetapkan dalam SNI 01.4852-1998 dan Pedoman BSN 1004 : 2002. Prosedur ini menjelaskan metode untuk mengidentifikasi, mengevaluasi, menangani pengaduan konsumen dan menarik kembali produk yang dikeluhkan oleh konsumen.

Tahapan penarikan produk (recall) yang dilakukan oleh perusahaan CV.Ruyaprima Utama adalah Bagian penanggung jawab produksi

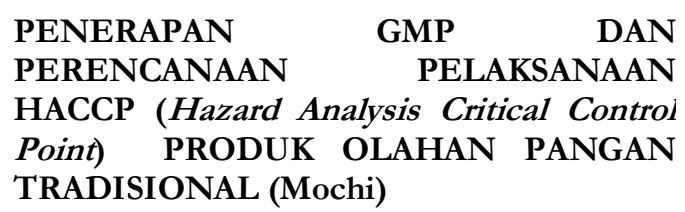

mengidentifikasi produk yang dikeluhkan berdasarkan nama produk, jenis kemasan, tanggal pengiriman, jumlah dan masalah yang dikeluhkan.

15. Kendala Dalam Penerapan Sistem HACCP.

Menurut Ditjen Pengawasan Obat dan Makanan (1996), HACCP sangat berguna bagi industri pangan, yaitu dalam hal : mencegah penarikan produk, mencegah penutupan pabrik, meningkatkan jaminan keamanan produk pangan, pembenahan dan pembersihan pabrik, mencegah kehilangan pembeli atau pasar, meningkatkan kepercayaan konsumen dan mencegah pemborosan

WILDAN WIBAWA PERDANA 
biaya atau kerugian yang mungkin timbul karena masalah keamanan produk pangan. Pengamatan dan wawancara di CV. Ruyaprima Utama untuk mengimplementasikan dan mengembangkan rencana HACCP menghadapi hambatan.

Hambatan psikologis terhadap karyawan yang ditunjuk oleh pihak manajemen sebagai anggota tim HACCP sangat berpengaruh. Pemahaman tentang sistem HACCP masih rendah dan adanya pekerjaan tambahan untuk membantu mempersiapkan dokumen. Pimpinan manajemen mempunyai hambatan organisasi, karena dalam mengimplementasikan dan mengembangkan rencana sistem HACCP, perusahaan harus menyediakan tim HACCP yang anggota harus kompeten di bidang, multidisiplin ilmu. CV. Ruyaprima Utama harus mempunyai rencana untuk mengembangkan sumber daya manusia yang dimilikinya dalam rencana menerapkan dan mengembangkan sistem HACCP.

\section{Rekomendasi Untuk Pengembangan Sistem HACCP Di Perusahaan}

Stevenson (1999), Sistem HACCP dikatakan bersifat komprehensif, karena sistem HACCP ini berkaitan erat dengan ramuan/ingredien pangan, proses pengolahan dan tujuan penggunaan produk pangan selanjutnya. Kajian terhadap kondisi sistem manajemen mutu, keamanan pangan, dan rencana HACCP Plan di CV. Ruyaprima Utama, dapat direkomendasikan beberapa sebagai berikut :

1. Perbaikan (Improvement) Penerapan GMP di CV. Ruyaprima Utama dengan menggunakan formulir/lembar kerja pemeriksaan GMP sarana produksi pangan yang dikeluarkan oleh Badan Pengawas Obat dan Makanan (Badan POM). Pemperbaiki penyimpangan direkomendasikan :

a. Penugaskan penanggung jawab produksi untuk mengawasi dan memantau dalam sanitasi yang dapat diamati secara langsung.

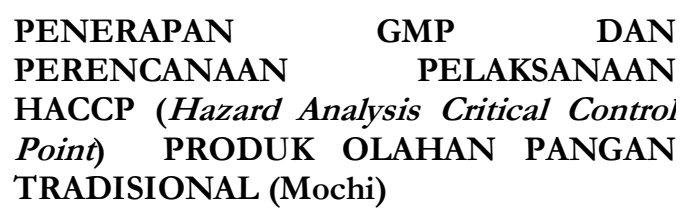

b. Pemasangan pembatas untuk mencegah adanya kontaminasi silang dari debu, kotoran dan serangga.

c. Pengendalikan hama serangga dilakukan dengan memasang insecta trap, dilakukan penyemprotan, dan dipasang lem perangkap lalat.

d. Pemeriksaan kesehatan karyawan secara berkala, khususnya karyawan produksi yang menangani produk secara langsung,

e. Penanggung jawab produksi bertugas memantau kebersihan karyawan dan memperhatikan aspek sanitasi, serta memantau kesehatan karyawan yang bisa diamati secara langsung.

g. Pengaturan dan pengelompokan bahan baku, bahan tambahan, produk, kemasan, dan bahan kimia.

h. Memperbaiki fasilitas sanitasi karyawan.

i. Meningkatkan efektiftas program pembersihan dan sanitasi di ruang produksi,

j. Program pelatihan yang berkelanjutan untuk peningkatan kesadaran dan sikap karyawan terhadap sanitasi, sehingga sikap dan perilaku karyawan (attitude) dalam menerapkan SOP dan GMP lebih konsisten.

2. Pengembangan Sistem Manajemen Keamanan Pangan Berdasarkan HACCP di CV. Ruyaprima Utama dapat direkomendasikan sebagai berikut :

a. Melakukan komunikasi eksternal dengan pemasok tentang kebijakan mutu dan keamanan di perusahaan;

b. Melakukan kaji ulang terhadap rencana HACCP) sebelum diaplikasikan di perusahaan.

c. Validasi dan verifikasi terhadap rencana HACCP yang ditetapkan di perusahaan.

d. Melakukan perbaikan yang diperlukan dan melakukan validasi kembali jika ada perubahan dalam rencana HACCP tersebut.

e. Melakukan sertifikasi sistem HACCP yang telah yang terlah diterapkan.

Rekomendasi Perubahan Tata Letak di Perusahaan CV. Ruyaprima Utama

Menurut Wignjosoebroto (2003), Tata letak pabrik adalah tata cara pengaturan fasilitas-fasilitas pabrik guna

WILDAN WIBAWA PERDANA 
menunjang kelancaran proses produksi. Pengaturan tersebut akan memanfaatkan luas area untuk penempatan mesin atau fasilitas penunjang produksi lainnya, kelancaran gerakan-gerakan material, penyimpanan material (storage) baik yang bersifat temporer maupun permanen, personil pekerja dan sebagainya.

Analisis GMP, SSOP dan HACCP yang dilanjutkan dengan pengecekan keefisienan proses produksi didapatkan perancangan tata letak usulan dapat dilihat pada Lampiran1.

Tata letak usulan ini dapat meningkatkan keamanan pada produk dan efesien dalam bekerja. Potensi bahaya yang tidak berhubungan dengan tata letak dapat diminimalisasi dengan peningkatan pengawasan, penegasan peraturan, pendokumentasian secara lengkap, dan pelatihan secara berkelanjutan. Potensi bahaya dapat minimalisasi dengan adanya peraturan yang mendukung, yaitu sebagai berikut:

1. Pemakaian perlengkapan seragam karyawan secara lengkap

2. Penggunaan kasa untuk ventilasi dan pintu yang terbuka

3. Perbaikan lantai dan dinding sesuai aturan untuk keamanan pangan

\section{KESIMPULAN DAN SARAN}

\section{Kesimpulan}

1. Hasil evaluasi terhadap kondisi persyaratan kelayakan dasar atau good manufacturing practice (GMP) di perusahaan CV. Ruyaprima Utama menunjukkan kondisi persyaratan kelayakan dasar di perusahaan tersebut ditemukan 9 penyimpangan; yaitu 6 penyimpangan mayor dan 3 penyimpangan minor yang terbagi menjadi 7 (tujuh) bagian, yaitu : aspek bangunan 2 kategori minor, aspek fasilitas sanitasi 1 kategori minor, aspek higiene karyawan (kesehatan karyawan, kebersihan karyawan, kebiasaan karyawan) 2 kategori mayor, aspek penyimpanan 1 kategori mayor, aspek pemeliharaan sarana pengolahan dan

\footnotetext{
PENERAPAN

GMP

PERENCANAAN PELAKSANAAN

HACCP (Hazard Analysis Critical Control

Point) PRODUK OLAHAN PANGAN

TRADISIONAL (Mochi)
}

sanitasi serta pengendalian hama 1 kategori mayor, serta aspek manajemen dan pelatihan 1 kategori mayor.

2. Standard Sanitation Operating Procedures (SSOP) merupakan suatu prosedur standar yang dapat mencakup seluruh area dalam memproduksi suatu produk pangan mulai dari kebijakan perusahaan, tahapan kegiatan sanitasi, petugas yang bertanggung jawab melakukan sanitasi, cara pemantauan, hingga pendokumentasian melalui evaluasi GMP.

3. Sembilan penyimpangan yang terdapat di perusahaan harus diperbaiki sebelum menerapkan sistem HACCP, prioritas yang perlu diperbaiki lebih dahulu adalah sebagai berikut : Prioritas pertama, berkaitan dengan aspek higiene karyawan (kesehatan karyawan, kebersihan karyawan dan kebiasaan karyawan) yang masuk dalam 2 kategori mayor; Prioritas kedua berkaitan dengan aspek pemeliharaan sarana pengolahan dan sanitasi serta pengendalian hama yang masuk dalam 1 kategori mayor, aspek manajemen dan pelatihan yang masuk dalam 1 kategori mayor; dan Prioritas ketiga/terakhir adalah berkaitan dengan aspek bangunan yang masuk dalam 2 kategori minor dan aspek fasilitas sanitasi yang masuk dalam 1 kategori minor.

4. Tahapan penyusunan rencana HACCP (HACCP Plan) untuk produksi mochi di CV. Ruyaprima Utama, terdapat dua tahap yang masih perlu diperbaiki dan di review kembali, yaitu pada pembentukan tim HACCP perusahaan masih perlu mempersiapkan peningkatan kompetensi personil tim HACCP yang masih kurang lengkap untuk mendukung implementasi sistem HACCP, serta tahap verifikasi berupa persiapan audit internal dan peninjauan rekaman hasil uji coba implementasi sistem HACCP untuk mengetahui dan memastikan efektifitas rencana HACCP. 
5. Hasil analisis bahaya untuk produksi mochi pada CV. Ruyaprima Utama di Cianjur menunjukkan bahwa kandungan bakteri patogen yang diuji yaitu Salmonella, E. coli dan Staphylococcus dan kapang adalah negatif. Sedangkan jumlah angka lempeng total (ALT) menunjukkan sebagian besar <100 koloni per gram, hasil ini masih di bawah batas maksimal yang dipersyaratkan sebesar 106koloni/gram.Data analisis kapang menunjukkan negatif. Data ini menunjukkan bahwa cemaran mikroba yang ada dalam produk mochi bukan merupakan suatu bahaya potensial bagi keamanan produk mochi yang dihasilkan oleh CV. Ruyaprima Utama.

6. Berdasarkan identifikasi CCP yang telah dilakukan, didapatkan dua proses yang memiliki CCP yaitu proses pemanasan gula dengan cara dimasak hingga mencair dan proses pencetakan secara manual dimana terjadi kontak langsung dengan karyawan.

7. Setelah dilakukan upaya perbaikan tata letak fasilitas pabrik yang memperhatikan faktor keamanan pangan, yaitu GMP, SSOP, dan HACCP, maka beberapa hal dapat meningkat lebih baik.

\section{Saran}

Rekomendasi yang dapat diberikan berdasarkan hasil obervasi, pemeriksaan, dan penilaian adalah Penugaskan penanggung jawab produksi untuk mengawasi dan memantau dalam sanitasi, Pemasangan pembatas untuk mencegah adanya kontaminasi silang dari debu, kotoran dan serangga, Memasang insecta trap sebagai pengendalikan hama serangga.Pemeriksaan kesehatan karyawan secara berkala, Memantau kebersihan karyawan dan memperhatikan aspek sanitasi, Pengaturan dan pengelompokan bahan, bahan, Memperbaiki fasilitas sanitasi karyawan, Meningkatkan efektiftas program pembersihan dan sanitasi di ruang produksi, Program pelatihan yang berkelanjutan untuk peningkatan kesadaran

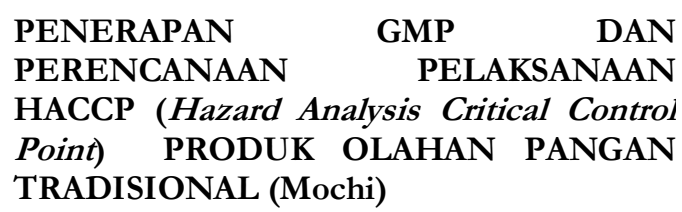

dan sikap karyawan terhadap sanitasi, sehingga sikap dan perilaku karyawan (attitude) dalam menerapkan SOP dan GMP lebih konsisten. Pengembangan Sistem Manajemen Keamanan Pangan Berdasarkan HACCP di CV. Ruyaprima Utama dapat direkomendasikan adalah Melakukan komunikasi eksternal dengan pemasok tentang kebijakan mutu dan keamanan di perusahaan, Melakukan kaji ulang terhadap rencana HACCP) sebelum diaplikasikan di perusahaan, Validasi dan verifikasi terhadap rencana HACCP yang ditetapkan di perusahaan, Melakukan perbaikan yang diperlukan dan melakukan validasi kembali jika ada perubahan dalam rencana HACCP tersebut, Melakukan sertifikasi sistem HACCP yang telah yang terlah diterapkan.

Rekomendasi tata letak dengan adanya peraturan yang mendukung adalah Pemakaian perlengkapan seragam karyawan secara lengkap, Penggunaan kasa untuk ventilasi dan pintu yang terbuka, Perbaikan lantai dan dinding sesuai aturan untuk keamanan pangan, serta perlu diadakan pengujian terhadap bahan baku secara berkala.

\section{DAFTAR PUSTAKA}

Antle, JM. 1995.Choice and Efficiency in Food safety Policy, American Enterprise Institute, Washington, DC.

Apple, J. M. 1990. Tata Letak Pabrik dan Pemindahan Barang, Edisi Tiga. Bandung:Institut Teknologi Bandung.

Assauri, S. 2008. Manajemen Produksi dan Operasi, Edisi Keempat. Jakarta:Fakultas Ekonomi Universitas Indonesia.

Badan Standarisasi Nasional (BSN). 1998. Sistem Analisa Bahaya dan Pengendalian Titik Kritis (HACCP) Serta Pedoman Penerapannya, Standar Nasional Indonesia, SNI 01-4852-1998.

Badan Standarisasi Nasional, BSN. 2002. Panduan Penyusunan Rencana Sistem Analisis Bahaya dan

\section{WILDAN WIBAWA PERDANA}


Pengendalian Titik Kritis (HACCP), Badan Standarisasi Nasional, Jakarta.

Bauman, HE. 1995. The Origin and Concept of HACCP, Didalam : Pearson, AM and Dutson, AT, editor, HACCP In Meat, Poultry and Fish Processing, Champman and Hall, New York.

Bintoro, VP. 2009. Peranan Ilmu dan Teknologi dalam Peningkatan Keamanan Pangan Asal Ternak, Makalah pada Forum Pengukuhan Guru Besar Fakultas Perternakan Universitas Diponegoro 22 Januari 2009, Semarang.

Badan POM (Badan Pengawas Obat dan Makanan). 1996. Undang-undang Republik Indonesia Nomor 7 tahun 1996 tentang Pangan.

Badan POM (Badan Pengawas Obat dan Makanan). 1999. Pedoman Pemeriksaan Sarana Pengolahan Makanan Kaleng Berasam Rendah, Direktorat Pengawasan Makanan dan Minuman Republik Indonesia.

Badan POM (Badan Pengawas Obat dan Makanan). 1999.Petunjuk Teknis Pemeriksaan Sarana Pengolahan Makanan Kaleng Berasam Rendah, Direktorat Pengawasan Makanan dan Minuman Republik Indonesia.

Badan POM (Badan Pengawas Obat dan Makanan). 2004. Peraturan Pemerintah (PP) No. 28 Tahun 2004 tentang Keamanan, Mutu dan Gizi Pangan, Badan Pengawas Obat dan Makanan, Jakarta.

Badan POM (Badan Pengawas Obat dan Makanan). 2005. (draft) Pedoman Pemeriksaan Sarana Pengolahan Saus Dalam Botol, Direktorat Inspeksi Dan Sertifikasi Pangan Badan Pengawas Obat Dan Makanan Republik Indonesia.

Badan POM (Badan Pengawas Obat dan Makanan). 2005. (draft) Petunjuk Teknis Pemeriksaan Sarana Pengolahan Saus Dalam Botol, Direktorat Inspeksi Dan Sertifikasi Pangan Badan Pengawas Obat Dan Makanan Republik Indonesia.
BPS (Badan Pusat Statistik). 2009. Direktori Industri Pengolahan, Badan Pusat Statistik, Jakarta.

BPS (Badan Pusat Statistik). 2011. Data Strategis BPS, Jakarta.

Departemen Kesehatan. 1996. Kumpulan Peraturan Perundang-undangan di Bidang Makanan, edisi IV, Direktorat Jendral Pengawasan Obat dan Makanan, Departemen Kesehatan, Jakarta.

Departemen Perindustrian. 2008. Potret Tiga Setengah Tahun Pelaksanaan Rencana Pembangunan Jangka Menengah Industri Manufaktur Tahun 2005-2009, Laporan Departemen Perindustrian Tahun 2008, Departemen Perindustrian, Jakarta.

Dewanti, R dan Nuraida, L. 2001. Keamanan Pangan Fungsional dan Suplemen Berbasis Pangan Tradisional, Prosiding Seminar Nasional Pangan Tradisional: Basis bagi Industri Pangan Fungsional dan Suplemen, Pusat Kajian Makanan Tradisional IPB Bogor.

Ditjen Pengawasan Obat dan Makanan, 1996.Pedoman Umum HACCP (Hazard Analysis Critical Control Point), Ditjen POM, Departemen Kesehatan, Jakarta.

FAO/WHO, Food and Agricultural Organization/World Health Organization. 1997. Hazard Analysis and Critical Control Point (HACCP) System and Guidelines for Its Application, Anex to CAC, Rev. 3, Rome, Italy.

Farina, EMQ and Reardon, T. 2000.Agrifood grades and standards in the extended Mercosur : their role in the changing agrifood system. American Journal of Agricultural Economics.

Hanani, N. 2009.Indonesia Tahan Pangan dan Gizi . 2015. Makalah Workshop II Ketahanan Pangan. Jawa Timur.

Hariyadi, P and Dewanti-Hariyadi, R. 2003.The Need of Communicating Food Safety In Indonesia. Di dalam "Food

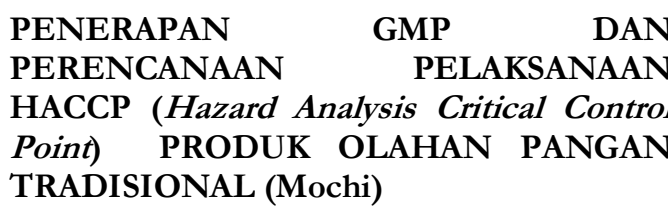

WILDAN WIBAWA PERDANA 
Quality; A Challenge For North And South", pp. 265-274, A publication of IAAS Belgium vz, Coupure Links 653 B-9000 Gent, Belgiu.

Hariyadi, Purwiyatno. 2007. Upaya Peningkatan Keamanan, Mutu, dan Gizi Pangan melalui Ilmu dan Teknologi Pangan, Southeast Asian Food Science and Technology (SEAFAST) Center IPB, Bogor.

Hariyadi, Purwiyatno. 2008. Beban Ganda: Permasalahan Keamanan Pangan di Indonesia. Artikel Pangan Edisi No. 51/XVIII/Juli-September/2008.

Hariyadi, Purwiyatno. 2008. Isu Terkini Terkait dengan Keamanan Pangan. Jurnal dalam Pra-Widyakarya Nasional Pangan dan Gizi IX. 9 Juni 2008.

Hariyadi, P. 2010. Penguatan Industri Penghasil Nilai Tambah Berbasis Potensi Lokal (Peranan Teknologi Pangan untuk Kemandirian Pangan). Jurnal Pangan. 19(4): 295301.

Heizer, J. dan B. Render. 2006. Manajemen Operasi, Edisi Ketujuh. Jakarta:Salemba Empat.

Hubeis, M. 1997. Menuju industri kecil profesional di era globalisasi melalui pemberdayaan manajemen industry, Orasi Ilmiah Guru Besar Tetap Ilmu Manajemen Industri, Fakultas Teknologi Pertanian. IPB Bogor.

Lawley R, Curtis L, and Davis J. 2008.The Food Safety Hazard Guidebook. Cambridge:RSC Publishing.

Mayers, Fred E. 1993. Plant Layout and Material Handling, Regents Prentice Hall.

Menpangan (Menteri Negara Urusan Pangan). 1996. Undang-Undang RI No. 7 Tahun 1996 tentang Pangan, Menteri Negara Urusan Pangan, Jakarta.

Menteri Negara Pangan dan Hortikultura. 1999. Peraturan Pemerintah (PP) No. 69 Tahun 1999 tentang Label dan Iklan Pangan, Menteri Negara Pangan dan Hortikultura, Jakarta.
Muhandri, T, dan D, Kadarisman. 2006. Sistem Jaminan Mutu Industri Pangan. Bogor: IPB Press.

NACMCF. 1998. Hazard Analysis and Critical Control Point System and Guidelines for Its Application. J. Food Protect.

Rahayu. 2008. Disain Peningkatan Daya Saing Industri Pengolahan Ikan Berbasis Perbaikan Kinerja Mutu Dalam Rantai Pasokan Ikan Laut Tangkapan Di Wilayah Utara Jawa Barat. Thesis. Fakultas Tehnologi Perikanan. Institut Pertanian Bogor.

Sapers GM, Gorny JR, and Yousef AE. 2006.Microbiology of Fruits and Vegetables. New York:CRC Press, Boca Raton, London.

Stevenson, KE. 1990.Implementing HACCP in Food Industry, Food Technology.

Stevenson, KE. 1999.Introduction to Hazard Analysis Critical Control point,Didalam : Stevenson, KE and Bernard, DT, editor, HACCP : $A$ SystematicApproach to Food Safet, third edition, the Food Processors Institute, Washington, DC.

Sudibyo, A, Rahayu, SE, Rohaman, MM, Ridwan, IN, Sirait, SD, Aprianita, N dan Sutrisniati, D. 2001.Pengembangan dan Penerapan Sistem HACCP (Hazard Analysis Critical Control Point) Pada Industri Pangan di Indonesia, Warta IHP New York ol. 18.

Sukarman, W. 2009. Pengelolaan Industri : Peran Industri Perbankan dalam Mendukung Sektor UMKM di Indonesia, Program Magister Profesional Industri Kecil Menengah Sekolah Pascasarjana. IPB.Bogor.

Suprapto.1999. Sistem Akreditasi dan Sertifikasi HACCP. Makalah Desiminasi pelaksanaan Akreditasi dan Sertifikasi HACCP. 7 Desember 1999. Badan Standardisasi Nasional (BSN). Jakarta.

Thaheer, Hermawan. 2005. Sistem Manajemen HACCP (Hazard

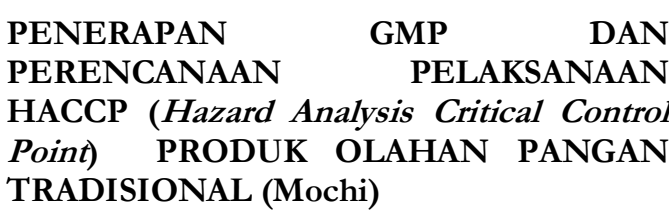

\section{WILDAN WIBAWA PERDANA}


Analysis Critical Control Points).

Jakarta: PT. Bumi Aksara.

[US-FDA] United States - Food and

Drug Administration. 1986.Part

110- Federal Government Rules And

Regulations For Good Manufacturing

Practices. US Department of Health

and Human Services, MD 20740,

College Park.

WHO (World Health Organization. 1999.Report of WHO Food Safety

Programme: Strategies for Strategies for Implementing HACCP in Small and/or Less Developed Businesses, The Netherlands The Hague.

Wignjosoebroto, Sritomo. 2003. Tata Letak Pabrik dan Pemindahan Bahan. Jakarta:Gama Widya.

Winarno, FG. 2002. Cara Berproduksi Makanan Yang Baik. Makalah Training Auditor Sistem HACCP. MBrio Training13-17 Mei 2002, Bogor.

Winarno FG, dan Surono. 2002. GMP Cara Pengolahan Pangan yang Baik. Bogor:MBRIO Press.

Ziggers, GW. 2000. HACCP, Vertical Coordination and Competitiveness in the Food Industry. Didalam Unnevehr, editor. The Economic of HACCP : Costs and Benefits. St. Paul, Minnesota, USA : Eagen Press. hlm : 269 - 284 . 